\title{
FATOR DE CRESCIMENTO SEMELHANTE À INSULINA-I NO PERÍODO DE FORMAÇÃO E TRANSFERÊNCIA DE IMUNIDADE PASSIVA PARA BEZERROS RECÉM-NASCIDOS
}

\author{
PATRICIA PAULETTI
}

Tese apresentada à Escola Superior de Agricultura "Luiz de Queiroz", Universidade de São Paulo, para obtenção do título de Doutor em Agronomia, Área de Concentração: Ciência Animal e Pastagens.

PIR A C I C A B A

Estado de São Paulo - Brasil

Novembro - 2003 


\title{
FATOR DE CRESCIMENTO SEMELHANTE À INSULINA-I NO PERÍODO DE FORMAÇÃO E TRANSFERÊNCIA DE IMUNIDADE PASSIVA PARA BEZERROS RECÉM-NASCIDOS
}

\author{
PATRICIA PAULETTI \\ Engenheiro Agrônomo
}

Orientador: Prof. Dr. RAUL MACHADO NETO

\author{
Tese apresentada à Escola Superior de \\ Agricultura "Luiz de Queiroz", Universidade de \\ São Paulo, para obtenção do título de Doutor \\ em Agronomia, Área de Concentração: Ciência \\ Animal e Pastagens. \\ PIR A C I C A B A \\ Estado de São Paulo - Brasil \\ Novembro - 2003
}




\section{Dados Internacionais de Catalogação na Publicação (CIP)} DIVISÃO DE BIBLIOTECA E DOCUMENTAÇÃO - ESALQ/USP

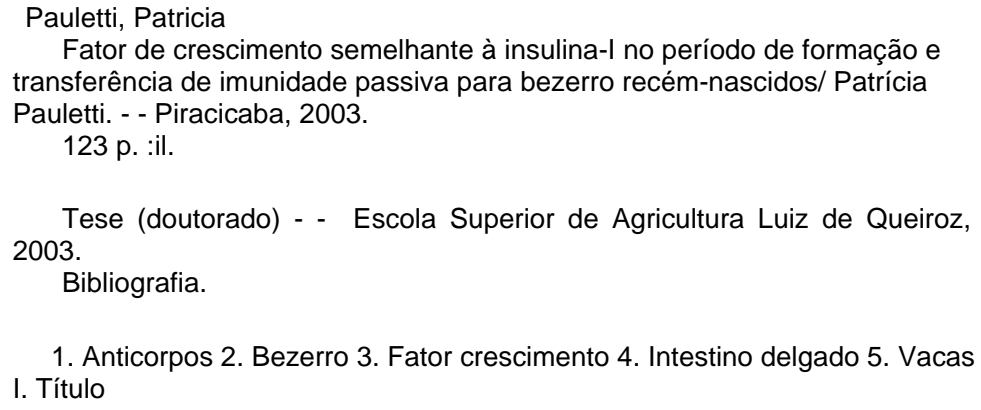

1. Anticorpos 2. Bezerro 3. Fator crescimento 4. Intestino delgado 5. Vacas I. Título

CDD 636.2

"Permitida a cópia total ou parcial deste documento, desde que citada a fonte - O autor" 
Aos meus queridos pais,

Osmar e Laurinda, por todo amor, dedicação e incentivo constantes

\section{OFEREÇO}

Ao querido Gérsio, por dividir comigo sua história e por me ajudar a construir a minha 


\section{AGRADECIMENTOS}

Ao Prof. Dr. Raul Machado Neto pela amizade e confiança, por seu exemplo de dedicação, por seu apoio irrestrito e incentivo constantes;

Ao Prof. Dr. Raul Dantas d'Arce pela simpatia e amizade presentes em todos esses anos;

Ao Prof. Dr. Dante P. D. Lanna pelo apoio, sugestões e pela coorientação deste trabalho;

Ao Prof. Dr. José Gilberto H. Vieira, pelo apoio e pelo consentimento para a realização das análises do IGF-I;

Ao Prof. Dr. Eduardo F. Delgado pela amizade, colaboração e pelas palavras de incentivo;

À querida amiga Adriana que, como eu, é autora dessa tese, pelo companheirismo, paciência e amizade presentes em todos os momentos;

À amiga Liris pela recente amizade e por suas carinhosas palavras de incentivo que tanto me ajudaram;

À Rosana, Ana Cecília e Marcelo, que mesmo distantes estiveram sempre presentes me apoiando e incentivando;

Aos amigos Carlos, Marina, Francisco, Tuka e Ana Paula pelo apoio, amizade e convivência;

À Cláudia Paro de Paz, pela ajuda com as análises estatísticas;

Aos funcionários do Departamento de Zootecnia e do setor de Zoologia Agrícola, José Luiz, Lásaro, Vera Lúcia e Sônia, pelo carinho e amizade durante todos os anos de convivência; 
À Granja Leiteira Santa Rita e ao Sr. Roberto Jank Júnior pelo consentimento e facilidades colocadas a disposição, permitindo a realização desse trabalho;

Aos funcionários da Granja Leiteira Santa Rita, em especial ao "Mingo", pelo carinho que nos receberam e por toda ajuda;

Às bibliotecárias Eliana Maria Garcia e Silvia Zinsly, pela correção do original;

À Fundação de Amparo à Pesquisa do Estado de São Paulo - FAPESP, pelo apoio financeiro destinado a este trabalho;

E finalmente, a todos aqueles que direta ou indiretamente deram sua contribuição, permitindo a realização deste trabalho. 


\section{SUMÁRIO}

Página

LISTA DE FIGURAS................................................................... viii

LISTA DE TABELAS .................................................................

RESUMO

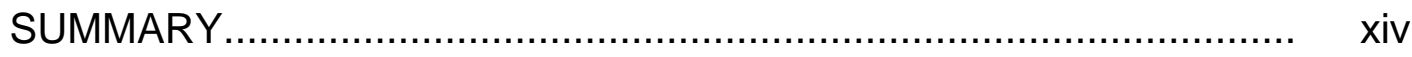

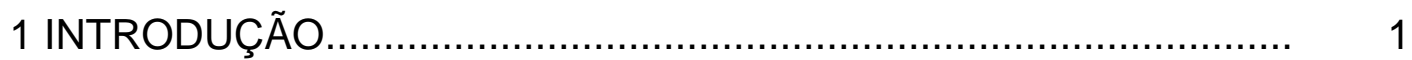

2 REVISÃO DE LITERATURA.................................................. 3

2.1 Fatores de crescimento semelhantes à insulina - sistema IGF....... 3

2.2 Receptores de IGF............................................................. 8

2.3 Proteínas de ligação - IGFBPs................................................. 10

2.4 IGFs nas secreções lácteas........................................................ 19

2.5 IGFs e o desenvolvimento do recém-nascido.............................. 25

3 MATERIAL E MÉTODOS ..................................................... 31

3.1 Animais e tratamentos............................................................. 31

3.2 Manejo dos animais................................................................ 32

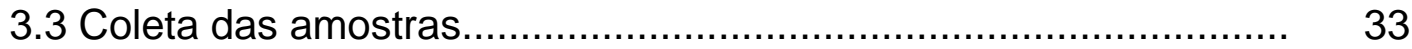

3.4 Análise das amostras........................................................... 34

3.4.1 Microscopia óptica........................................................... 34

3.4.2 Análise morfométrica...................................................... 35

3.4.3 Análise da imunoglobulina G - IgG...................................... 38

3.4.4 Análise da proteína total - PT................................................. 39 
3.4.5 Análise do fator de crescimento semelhante à insulina-I - IGF-I. $\quad 39$

3.4.6 Análise de acidos graxos não-esterificados - AGNE.................. 40

3.4.7 Análises bromatológicas..................................................... 41

3.4.8 Delineamento experimental e análise estatística........................ 43

4 RESULTADOS E DISCUSSÃO................................................... 45

4.1 Escore corporal e ácidos graxos não-esterificados....................... 45

4.2 IGF-I, IgG e PT séricos das vacas.......................................... 50

4.3 IGF-I e IgG no colostro e secreções lácteas................................. 61

4.4 IGF, IgG e PT séricos dos bezerros.......................................... 69

4.5 Peso corporal, peso de órgãos e morfometria da mucosa

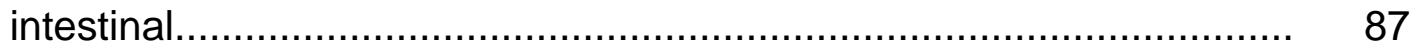

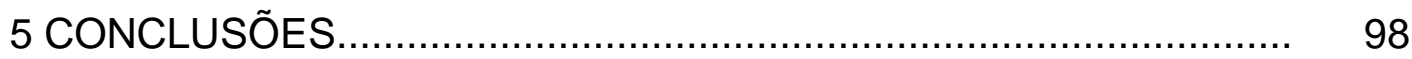

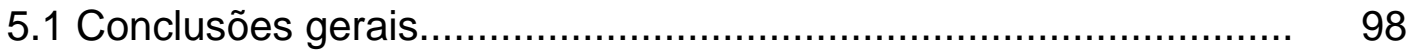

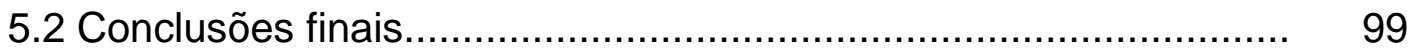

REFERÊNCIAS BIBLIOGRÁFICAS............................................... 100

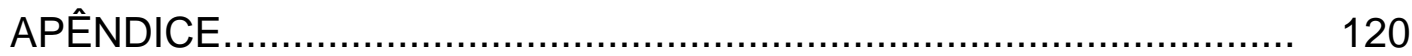




\section{LISTA DE FIGURAS}

Página

1 Estruturas terciárias da insulina e IGF-I......................................... 4

2 Atividades endócrinas, parácrinas e autócrinas dos IGFs reguladas pelo hormônio do crescimento, pelas proteínas ligadoras dos fatores de crescimento semelhantes à insulina (IGFBPs) e por seus receptores................................................... 6

3 Estrutura dos receptores do IGF-I e IGF-II ................................ 9

4 Mobilização dos IGFs do complexo plasmático de 150 kDa por proteólise limitada da IGFBP-3.............................................. 15

5 Localizações fisiológicas das IGFBPs......................................... 18

6 Representação esquemática do sistema teste de arcos

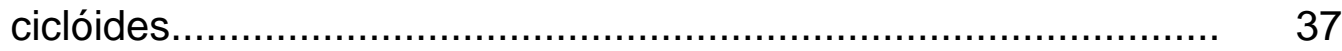

7 Concentrações séricas de ácidos graxos não-esterificados (média \pm desvio padrão) durante o período de tratamento e na data de parição.

8 Concentrações de IGF-I (média \pm desvio padrão) no colostro e

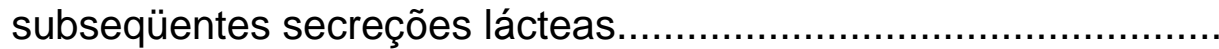

9 Concentrações de IgG (média \pm desvio padrão) no colostro e

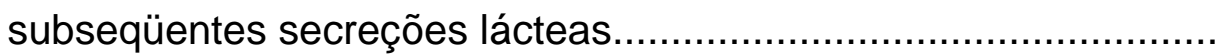

10 Flutuação sérica de IGF-I $(\mathrm{ng} / \mathrm{mL})$ dos bezerros distribuídos em função do tratamento das mães e da massa de IGF-I $(\mu \mathrm{g})$ consumida do colostro 
11 Regressão entre a concentração sérica de IGF-I (ng/mL) às 12 e 24 horas de vida e a massa de IGF-I $(\mu \mathrm{g})$ consumida do

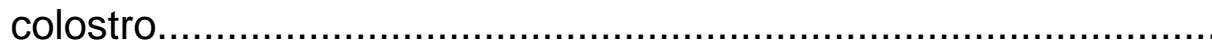

12 Regressão entre a concentração sérica de $\lg G(\mathrm{mg} / \mathrm{mL})$ às 12 e 24 horas de vida e a massa de IgG (mg) consumida do

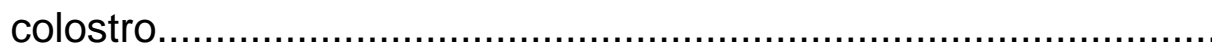

13 Flutuação dos níveis séricos de PT (g/100mL) e $\mathrm{lgG}(\mathrm{mg} / \mathrm{mL})$ dos bezerros do nascimento até sete dias de vida.

14 Regressão entre IGF-I sérico $(\mathrm{ng} / \mathrm{mL})$ e peso vivo $(\mathrm{kg})$ dos bezerros ao nascimento. 


\section{LISTA DE TABELAS}

Página

1 Características estruturais das IGFBPs........................................ 13

2 Propriedades físicas e biológicas das IGFBPs.............................. 13

3 Comparação entre os níveis de IGF-I e IGF-II no colostro e leite de diferentes espécies................................................................ 21

4 Proporções de ingredientes utilizados e composição bromatológica da ração total consumida pelas vacas durante o período de tratamento......................................................... 42

5 Escore corporal médio das vacas durante o período de

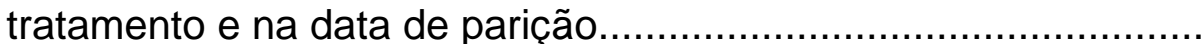

6 Concentrações séricas de ácidos graxos não-esterificados ( $\mu \mathrm{mol} / L$ ) durante o período de tratamento e na data de parição.....

7 Concentrações séricas de IGF-I (ng/mL) das vacas durante o período de tratamento e na data de parição

8 Concentrações séricas de $\operatorname{lgG}(\mathrm{mg} / \mathrm{mL})$ das vacas durante 0 período de tratamento e na data de parição.

9 Concentrações séricas de PT $(\mathrm{g} / 100 \mathrm{~mL})$ das vacas durante o período de tratamento e na data de parição.

10 Concentrações médias de IGF-I ( $\mathrm{ng} / \mathrm{mL})$ referentes ao colostro e subseqüentes secreções lácteas.

11 Concentrações médias de $\operatorname{lgG}(\mathrm{mg} / \mathrm{mL})$ referentes ao colostro e subseqüentes secreções lácteas 
12 Concentrações séricas de IGF-I $(\mathrm{ng} / \mathrm{mL})$ dos bezerros do

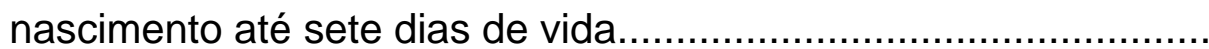

13 Concentrações séricas de IGF-I $(\mathrm{ng} / \mathrm{mL})$ dos bezerros do nascimento até sete dias de vida redistribuídos em dois grupos em função da massa de IGF-I $(\mu \mathrm{g})$ ingerida do colostro (médias corrigidas pela covariável IGF-I sérico ao nascimento)..................

14 Concentrações séricas de $\operatorname{lgG}(\mathrm{mg} / \mathrm{mL})$ dos bezerros do nascimento até sete dias de vida.

15 Concentrações séricas de PT $(\mathrm{g} / 100 \mathrm{~mL})$ dos bezerros do nascimento até sete dias de vida.

16 Peso vivo $(\mathrm{kg})$ e de órgãos $(\mathrm{g})$ dos bezerros nas três datas de abate.

17 Volume parcial ( $\mathrm{V} v$ \%) da mucosa absortiva do intestino delgado dos bezerros nas três datas de abate 


\title{
FATOR DE CRESCIMENTO SEMELHANTE À INSULINA-I NO PERÍODO DE FORMAÇÃO E TRANSFERÊNCIA DE IMUNIDADE PASSIVA PARA BEZERROS RECÉM-NASCIDOS
}

\author{
Autora: PATRICIA PAULETTI \\ Orientador: Prof. Dr. RAUL MACHADO NETO
}

\section{RESUMO}

Quarenta e duas vacas Holandesas, em gestação e multíparas, e os respectivos bezerros recém-nascidos foram utilizados para determinar se as concentrações de IGF-I no colostro e secreções lácteas podem ser alteradas em resposta à mudanças na concentração sérica de IGF-I pré-parto, avaliar comparativamente a flutuação sérica pré-parto de IGF-I em relação a IgG, bem como as flutuações séricas de IGF-I e IgG nos bezerros na primeira semana de vida e, adicionalmente, alterações na mucosa intestinal dos mesmos. As vacas foram distribuídas ao acaso em dois grupos de 21 animais, o grupo tratado recebeu $500 \mathrm{mg}$ de somatotropina bovina recombinante (rbST) e o grupo controle recebeu injeções de vitamina E. Ambos tratamentos iniciaram 35 dias pré-parto e foram administrados em intervalos de 14 dias. Semanalmente, foi observado o escore corporal e foram coletadas amostras de sangue até a data de parição. Foram coletadas amostras do colostro e das secreções lácteas, 
diariamente, por sete dias pós-parto. Os bezerros recém-nascidos foram distribuídos ao acaso, em um arranjo fatorial $2 \times 3$, correspondendo ao tratamento das mães (controle ou rbST) e às datas de abate (ao nascimento, aos dois dias de idade e aos sete dias de idade). Diariamente, foram coletadas amostras de sangue até a data de abate. Para as análises estereológicas amostras foram coletadas de cinco regiões do intestino delgado. O escore corporal e a concentração sérica de ácidos graxos não-esterificados não diferiram entre os grupos durante todo o período experimental $(P>0,05)$. Os grupos rbST e controle apresentaram diferenças significativas quanto às concentrações séricas de IGF-I na segunda e quarta semanas após o início do período experimental $(P<0,05)$, em resposta às aplicações do rbST, no entanto não foram encontradas diferenças entre os tratamentos no parto $(P>0,05)$. A concentração de IGF-I foi superior no colostro das vacas tratadas com rbST $(P<0,05)$, não diferindo nas secreções subseqüentes. As concentrações séricas de IgG não diferiram entre os tratamentos durante todo o período experimental, bem como as concentrações de IgG do colostro e demais secreções lácteas $(P>0,05)$. Não foram encontradas diferenças entre os tratamentos nas concentrações séricas de IGF-I dos bezerros até o sétimo dia de vida, como também não foram encontradas diferenças entre as concentrações séricas de IgG nos bezerros após 24 horas de vida $(P>0,05)$. O peso dos órgãos e 0 volume parcial $(\mathrm{Vv})$ da mucosa absortiva não diferiram entre os tratamentos nas três datas de abate, observando-se somente diferenças significativas entre as datas de abate. A porção do jejuno médio apresentou maior $\mathrm{Vv}$ em relação aos outros segmentos do intestino delgado ao nascimento e aos sete dias de vida. A aplicação de rbST no período seco influenciou somente a concentração de IGF-I no colostro, não alterando as concentrações séricas nos bezerros até o sétimo dia de vida, como também o $\mathrm{V} v$ da mucosa absortiva do intestino delgado. 


\title{
INSULIN-LIKE GROWTH FACTOR-I DURING THE FORMATION AND TRANSFER OF PASSIVE IMMUNITY TO NEWBORN CALVES
}

\author{
Author: PATRICIA PAULETTI \\ Adviser: Prof. Dr. RAUL MACHADO NETO
}

\section{SUMMARY}

Forty-two Holstein cows, in gestation and multiparous, and their newborn calves were used to evaluate if insulin-like growth factor-I (IGF-I) in colostrum and subsequent mammary secretions could be influenced by changes in blood serum IGF-I and compare its temporal changes with the serum immunoglobulin G (IgG) in pre-partum period, as well as the temporal changes in serum IGF-I and IgG in newborn calves during the first week of life, and also, alterations in its intestinal mucosa. Cows were randomly assigned in two groups of twenty-one animals, treated group was injected $500 \mathrm{mg}$ of recombinant bovine somatotropin $(\mathrm{rbST})$, and the control group received vitamin $\mathrm{E}$ injection. Both treatments started 35 days pre-partum and were administered every 14 days until partum. Weekly body condition scores were measured and blood was collected until partum. Colostrum and mammary secretions were collected daily for seven days pos-partum. Newborn calves were randomly assigned to a 2X3 factorial arrangement, which the factors depended on mother's treatment (control and rbST) and slaughter date (just after birth, two days of life and seven days of life). 
Blood was collected daily until slaughter. For stereological analysis samples were taken from five sites from small intestine. Body condition scores and nonesterified fatty acid concentration didn't differ between the groups during the experimental period $(P>0,05)$. Groups differed about serum IGF-I during prepartum $(P<0,05)$, which showed differences on second and fourth weeks of experimental period in response to rbST administration. However, no treatment differences were found at partum $(P>0,05)$. IGF-I concentration was higher in colostrum of cows treated with rbST $(P<0,05)$, but it didn't differ in subsequent mammary secretions. IgG serum concentration didn't differ between treatments during the experimental period, neither IgG concentration in colostrum and subsequent mammary secretions $(P>0,05)$. No differences were found either in calves' IGF-I levels from birth to seven days old or in IgG serum concentration after 24 hours of life $(P>0,05)$. Organ weight and mucosa partial volume $(\mathrm{VV})$ didn't differ between treatments in the three slaughter dates, only differences among the salughter dates were observed. Segment from the medium jejunum showed higher $\mathrm{V} v$ in relation to others segments at birth and seven days old. The administration of rbST during the dry period influenced only IGF-I concentration in colostrum, however colostrum IGF-I didn't affect calves' serum concentration up to seven days old, neither the mucosa $\mathrm{V} v$ of small intestine. 


\section{INTRODUÇÃO}

O colostro é a primeira secreção láctea produzida após o parto e, nos bovinos, consiste da mistura de secreções da glândula mamária e elementos do soro sangüíneo, principalmente imunoglobulinas, que se acumulam durante o período pré-parto. A importância do colostro para a sobrevivência do recémnascido já é há muito tempo conhecida, uma vez que as imunoglobulinas maternas adquiridas pelo recém-nascido, oriundas desta secreção, garantem níveis iniciais de anticorpos que viabilizam, em grande parte, a sobrevivência dos mesmos (Husband et al., 1972; Nocek et al., 1984; Baracat et al., 1997; Machado Neto et al., 1997; Quigley \& Drewry, 1998; Bessi et al., 2002ab; Pauletti et al. 2002; Quigley et al., 2002).

Em adição às imunoglobulinas e aos nutrientes, o colostro contém concentrações de hormônios e fatores de crescimento significativamente maiores que no sangue materno, os quais estão possivelmente associados ao desenvolvimento do recém-nascido, atuando no crescimento e maturação do trato digestivo (Bühler et al., 1998; MacDonald, 1999; Roffler et al., 2003).

Dentre os peptídeos bioativos das secreções lácteas estão os fatores de crescimento semelhantes à insulina I e II (IGFs), que juntamente com suas proteínas de ligação e seus receptores formam um sistema que tem sido um dos mais estudados de todos os fatores de crescimento conhecidos. A razão por esse grande interesse está relacionada ao fato do sistema ser encontrado 
em todos os tecidos e células e possuir numerosas funções em todos os estádios de desenvolvimento. Os IGFs são sintetizados e secretados principalmente pelo fígado e quando secretados por fontes extra-hepáticas agem, principalmente, no sítio de síntese (ação autócrina/parácrina). Os IGFs encontrados nas secreções lácteas podem agir como mediadores locais do desenvolvimento da glândula mamária e também, pelo fato de sua alta concentração no colostro e presença de receptores específicos para IGF-I no intestino de recém-nascidos, podem funcionar como mediadores maternos do crescimento e desenvolvimento no início da vida (Grosvenor et al., 1993; LeRoith et al., 1994; Hossner et al., 1997; LeRoith, 1999).

Há muitos anos o manejo tem sido orientado para o consumo cada vez maior e mais precoce do colostro de alto valor imunológico, assegurando a proteção inicial do recém-nascido, sem avaliar os outros fatores que acompanham essa secreção e que podem influenciar o início do desenvolvimento do animal. $O$ presente trabalho teve por objetivos determinar se as concentrações de IGF-I no colostro e secreções lácteas podem ser alteradas em resposta a mudanças na concentração sérica de IGF-I pré-parto, avaliar comparativamente a flutuação sérica pré-parto de IGF-I em relação a IgG, bem como as flutuações séricas de IGF-I e IgG nos bezerros na primeira semana de vida e, adicionalmente, alterações na mucosa intestinal dos mesmos. 


\section{REVISÃO DE LITERATURA}

\subsection{Fatores de crescimento semelhantes à Insulina - sistema IGF}

Em 1957, Salmon \& Daughaday identificaram um fator sérico que mediava a ação do hormônio do crescimento $(\mathrm{GH})$ sobre a cartilagem epifisária. Entre os anos de 1960 e 1970 foi verificado que esse fator estava presente na circulação formando um complexo com uma massa molecular maior que 100 kDa e, após tratamento ácido, o complexo liberava um pepitídeo ativo de 5 a $10 \mathrm{kDa}$ designado então de somatomedina. Duas somatomedinas foram identificadas em mamíferos e por sua semelhança estrutural com a pró-insulina (Figura 1), hoje são conhecidas como fatores de crescimento semelhantes à insulina (IGFs) e fazem parte da família da insulina consistindo da insulina, IGF-I, IGF-II e relaxina (Lee et al., 1993). As duas formas de IGFs são polipeptídeos de cadeia simples, retendo o peptídeo $\mathrm{C}$ intacto e apresentando um prolongamento do domínio A, chamado de domínio D (LeRoith et al., 1994). 


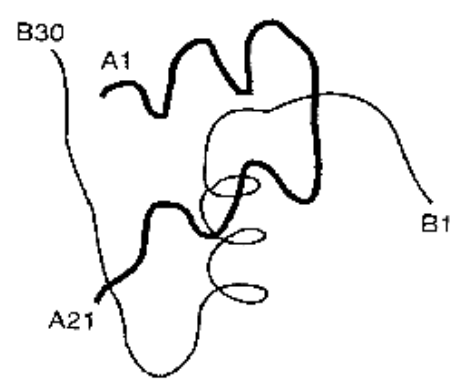

INSULINA

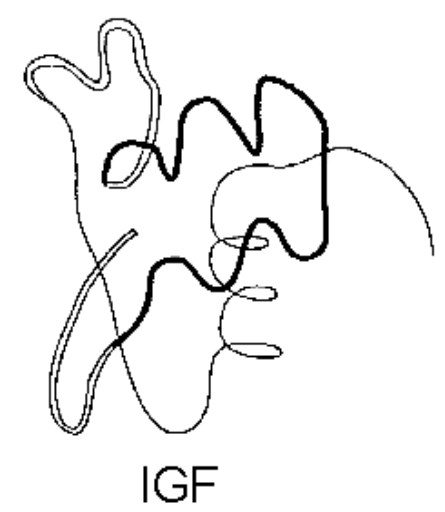

Figura 1 - Estruturas terciárias da insulina e IGF-I

Fonte: LeRoith et al. (1994)

A insulina e os peptídeos semelhantes à insulina fazem parte de uma super-família de peptídeos anabólicos representados hoje no reino animal. Sugere-se que a duplicação de um gene ancestral originou a insulina e os precursores dos IGFs, provavelmente na época do surgimento dos vertebrados (Kelley et al., 1996). Desde sua divergência, a insulina e os IGFs têm evoluído para papéis metabólicos distintos, ao menos parcialmente, pela existência de receptores, os quais se ligam aos seus ligantes heterólogos com menor afinidade em relação aos seus homólogos (Hossner et al., 1997; McCusker, 1998). 
Em adição a sua divergência molecular, a insulina e os IGFs possuem dois fatores adicionais que os separam funcionalmente. Em primeiro lugar, o gene da insulina é expresso exclusivamente nas células $\beta$-pancreáticas em um sítio anatômico onde a insulina é liberada diretamente para o fígado. Sob condições fisiológicas normais, a insulina regula o metabolismo intermediário pela interação com receptores no fígado, tecido adiposo e células musculares. Já os IGFs são expressos em uma variedade de tipos de células agindo como mediadores do crescimento, desenvolvimento e diferenciação celular (LeRoith et al., 1994).

Em segundo lugar, os IGFs se ligam nos fluidos biológicos à proteínas de ligação referidas como IGFBPs. Com uma alta afinidade pelos IGFs, as IGFBPs não somente bloqueiam o significativo potencial dos IGFs de interagirem com os receptores da insulina, como também são importantes moduladoras da interação IGF-receptor. No entanto, a insulina não possui afinidade por nenhuma das IGFBPs (Kelley et al., 1996; McCusker, 1998).

Os fatores de crescimento semelhantes à insulina I e II são sintetizados e secretados por muitos tecidos podendo agir localmente como fatores autócrinos e parácrinos, ou ainda como fatores de crescimento endócrinos que circulam no plasma e agem em sítios distantes (Figura 2). 


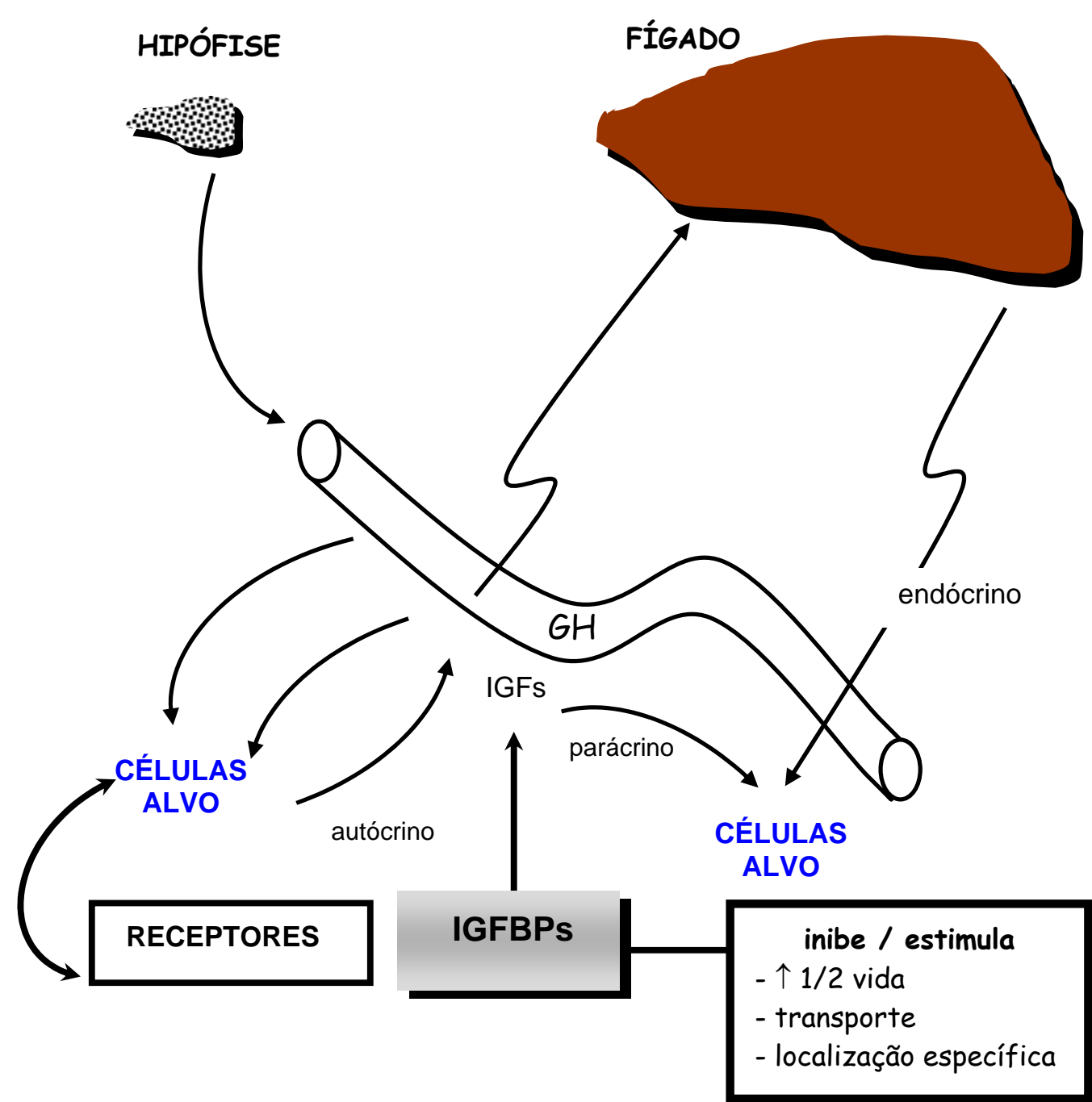

Figura 2 - Atividades endócrinas, parácrinas e autócrinas dos IGFs reguladas pelo hormônio do crescimento, pelas proteínas ligadoras dos fatores de crescimento semelhantes à insulina (IGFBPs) e por seus receptores

Fonte: Adaptado de Hossner et al. (1997) 
Os IGFs são conhecidos por estarem amplamente distribuídos e mediarem o crescimento, desenvolvimento e diferenciação, sendo que IGF-I tem a função de mediar as ações de promotor de crescimento do hormônio do crescimento in vivo, é responsável pelo aumento do transporte de aminoácidos para as células musculares e também, pelo aumento da síntese de proteínas, sendo que suas ações se dão por diferentes mecanismos (DePalo et al., 2001).

Em adição aos seus efeitos de promotor de crescimento, o IGF-I também mostra atividades semelhantes à insulina em alguns tecidos, nos quais ele inibe lipólise, aumenta oxidação de glicose no tecido adiposo e estimula o transporte de glicose e aminoácidos para os músculos (LeRoith et al., 1994; LeRoith, 1999). As funções do IGF-II não estão completamente definidas, no entanto o mesmo parece estar relacionado com o desenvolvimento pré-natal (Kiess et al., 1994).

As duas formas ligantes de IGFs são polipeptídeos de cadeias simples, que apresentam $70 \%$ de homologia na seqüência de aminoácidos. O IGF-I humano é formado por 70 aminoácidos e tem um peso molecular de 7,646 kDa. As seqüências de aminoácidos dos IGFs são altamente conservadas nos mamíferos: IGF-I bovino e suíno são idênticos ao IGF-I humano, enquanto IGF-I ovino difere somente por uma substituição da alanina por prolina no resíduo 66. O IGF-II humano é formado por 67 aminoácidos, com um peso molecular de 7,470 kDa. O IGF-II suíno difere da molécula humana somente por um aminoácido, enquanto o bovino e o ovino diferem da molécula humana por três e quatro aminoácidos, respectivamente (Hossner et al., 1997).

Uma outra forma de IGF-I foi isolada do colostro bovino, cérebro humano e útero de porcas, a forma truncada do IGF-I, Des(1-3)IGF-I ou também representada como -3N-IGF-I. Essa forma variante com 67 aminoácidos não apresenta o tripeptídeo Gly-Pro-Glu no domínio N-terminal (Ballard et al., 1996). Essa proteína provavelmente resulta de uma clivagem pós-tradução da molécula de IGF-I madura. Essa molécula modificada tem provado ser particularmente 
interessante, pois possui aproximadamente dez vezes a potência do IGF-I em vários tipos de células, onde age tanto na hipertrofia como na hiperplasia. Esse fato seria uma conseqüência da redução na afinidade de ligação com as IGFBPs, o que estaria ligado diretamente com a ausência do glutamato na posição 3. Esse aumento de potência permanece, em parte, quando Des(13)IGF-I é administrado in vivo, com efeitos anabólicos seletivos particularmente evidentes no tecido intestinal (Francis et al., 1998). Burrin et al. (1999), trabalhando com fornecimento de leite enriquecido de Des(1-3)IGF-I para ratos lactentes, observaram maiores taxas de síntese de proteína no estômago e intestino delgado em comparação aos animais controle.

\subsection{Receptores de IGF}

O IGF-I e o IGF-II interagem com receptores que são expressos em quase todos, senão todos os tecidos do corpo (Figura 3). Os receptores de membranas associados aos IGFs têm sido identificados e nomeados como tipo I e tipo II/manose-6-fosfato. O receptor do tipo I tem uma estrutura heterotetrâmica, a qual é homóloga ao receptor de insulina, apresentando peso molecular de aproximadamente 450kDa e é composto de duas subunidades $\alpha$, de 130 a 140 $\mathrm{kDa}$, e duas subunidades $\beta$, de 90 a $98 \mathrm{kDa}$, ligadas por pontes dissulfito. Esse receptor tem maior afinidade ao IGF-I, seguido do IGF-II e insulina (LeRoith et al., 1994). 


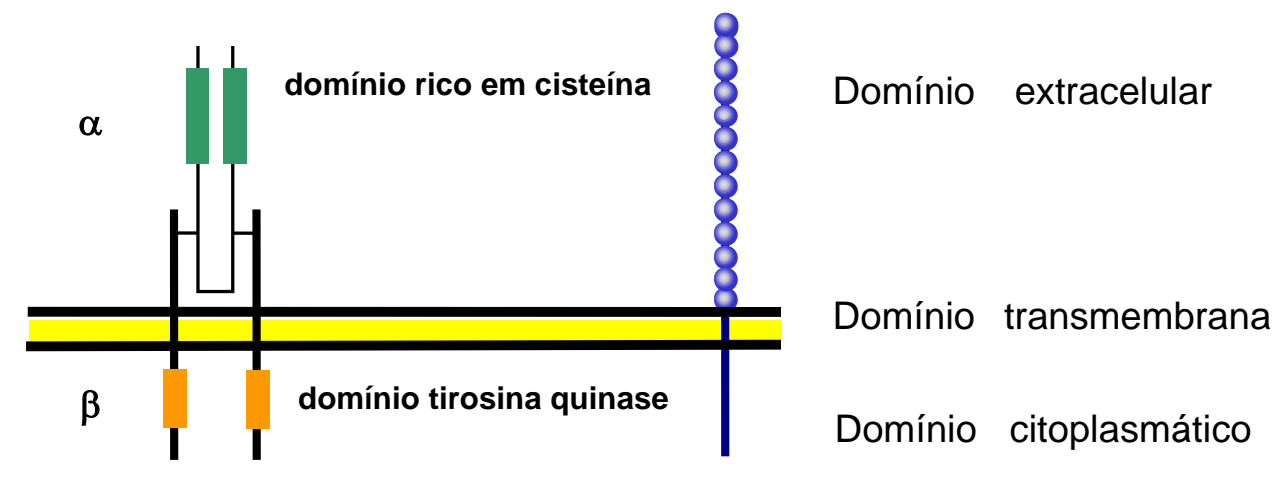

Receptor IGF-

Receptor IGF-

Figura 3 - Estrutura dos receptores do IGF-I e IGF-II

Fonte: LeRoith et al. (1994)

A ligação do IGF-I às subunidades $\alpha$ extracelulares resulta em mudanças na conformação das subunidades $\beta$. Três resíduos de tirosina dentro do domínio tirosina-quinase (tyr-1121,1135 e 1136) são os primeiros a serem fosforilados, com isso aumentando a atividade quinase do domínio em relação aos substratos intracelulares. Outros resíduos de tirosina na subunidade $\beta$ são fosforilados e podem ter função na tradução do sinal, enquanto acredita-se que a fosforilação de resíduos de serina também esteja envolvida (LeRoith et al., 1994; LeRoith, 1999).

A fosforilação de resíduos na subunidade $\beta$ cria sítios de ligação de alta afinidade para proteínas de sinalização. Dentre as proteínas sinalizadoras estudadas estão as proteínas da família do substrato do receptor da insulina (IRS), SHC, 14-3-3e, a subunidade p85 de fosfoinositol 3-quinase, a tirosina fosfatase PTP1D e mGRB10. A ligação de cada uma dessas proteínas tem a 
capacidade de ativar sistemas distintos de sinalização. A habilidade do receptor de IGF-I de se ligar e ativar diferentes proteínas pode representar um mecanismo de especificidade a um tipo celular, uma vez que a expressão dessas proteínas pode diferir entre tecidos e ao longo do desenvolvimento (Butler et al., 1998).

O receptor do tipo II (manose-6-fosfato - M6P) é uma grande glicoproteína que apresenta um extenso domínio extracelular que consiste de 15 repetições com tamanho médio de 147 aminoácidos cada, sendo que o mesmo não mostra semelhança ao receptor da insulina, não contendo atividade de tirosina-quinase (Kiess et al., 1994). Esse receptor liga duas classes de ligantes, IGF-II e enzimas lisossomais, carregando a marca de reconhecimento M6P. Quase todas as células de mamíferos expressam esse receptor, o qual liga IGF-II com alta afinidade, reconhecendo IGF-I fracamente e não se liga à insulina (Czech, 1989).

\subsection{Proteínas de ligação - IGFBPs}

Em muitas espécies os níveis séricos totais dos IGFs são maiores que $500 \mu \mathrm{g} / \mathrm{L}$, sendo esse nível muito superior à média necessária para estimular o crescimento celular. No entanto, o controle da atividade dos IGFs se dá por mecanismos independentes de mudanças nos níveis circulantes (Hossner et al., 1997). Alguns fatores principais controlam a atividade dos IGFs como estado nutricional do animal, alterações hormonais e sua associação às proteínas de ligação (McGuire et al., 1995; Rhoads et al., 2000). Os fatores de crescimento semelhantes à insulina I e II são encontrados quase inteiramente (95 a 99\%) em associação às IGFBPs. Essas proteínas se ligam a IGF-I e IGF-II com afinidade igual ou maior que seus respectivos receptores (Collet \& Candy, 1998).

Em adição ao seu papel de separar as atividades da insulina e dos IGFs, 
as IGFBPs têm, pelo menos em mamíferos, complexos papéis no sistema regulador do crescimento. As IGFBPs não agem meramente como transportadoras dos IGFs, mas conferem aos mesmos funcionalidade nos sistemas e especificidade nos tecidos alvo, em função de influenciarem diretamente na ligação e na interação com receptores específicos (Kelley et al., 1996). A especificidade do sistema não se limita somente a diferentes formas das IGFBPs, mas também a modificações pós-tradução que podem alterar sua atividade biológica. A isso, somam-se recentes pesquisas que têm evidenciado que algumas IGFBPs ou fragmentos das IGFBPs podem apresentar efeitos diretos independentes dos IGFs ou de seus respectivos receptores. Portanto, as IGFBPs possuem duas funções principais no animal, estabilizar os IGFs através da formação do complexo IGFBP-IGF e manter um pool circulante dos IGFs (Jones \& Clemmons, 1995; Clark, 1997).

A ocorrência das IGFBPs na circulação sangüínea foi primeiramente demonstrada em humanos pelos pesquisadores Hintz \& Liu em 1977, mas sua importância e complexidade não foram totalmente consideradas na época. Por limitações técnicas, somente na década de 80, com o progresso de análises relacionadas à purificação de proteínas e à biologia molecular, começou-se a obter maiores detalhes. As seis IGFBPs clonadas em mamíferos são bastante conservadas, dentro de uma mesma espécie as IGFBPs compartilham uma seqüência de aminoácidos na proteína com uma homologia de 50\%. As regiões mais altamente conservadas existem dentro do domínio N-terminal e também na região C-terminal, nessas regiões também podem ser observados um grande número de resíduos de cisteína (Jones \& Clemmons, 1995). A variação maior no número e composição de aminoácidos ocorre no terço médio da cadeia protéica, sugerindo que os aminoácidos específicos para ligação dos IGFs estão localizados nas regiões conservadas (Ferry et al., 1999).

As IGFBPs são similares em sua estrutura consistindo de 200 a 300 aminoácidos, possuem múltiplos modos de ação (endócrino, parácrino e 
autócrino) e dois mecanismos distintos (estimulador e inibidor) sendo expressas em quase todos os tecidos (Jones \& Clemmons, 1995). Os efeitos das IGFBPs dependem não somente da concentração e proporção relativa dessas proteínas no fluido extracelular, mas também de sua distribuição relativa entre o fluido extracelular e a superfície da célula. Mecanismos ainda não bem definidos devem fazer parte da expressão das diferentes formas das proteínas de ligação em determinadas condições fisiológicas, intermediando as ações dos IGFs (Hossner et al., 1997; Cohick, 1998).

Apesar das similaridades, as diferentes IGFBPs possuem propriedades estruturais, físicas e biológicas distintas, conforme pode ser observado nas Tabelas 1 e 2. Funcionalmente, a IGFBP- 6 tem uma afinidade 50 vezes maior ao IGF-II em relação ao IGF-I; IGFBP-1 exibe uma dinâmica hormonal e uma regulação metabólica e a IGFBP-3 é a mais abundante entre as proteínas de ligação na circulação. As IGFBPs 1, 2, 3 e 5 aumentam a atividade mitogênica dos IGFs in vitro, já a IGFBP-4 exibe somente efeitos inibidores, indicando que as formas e relativas proporções das IGFBPs presentes no fluido extracelular podem determinar a rede de efeitos dos IGFs (Rechler \& Clemmons, 1998). 
Tabela 1. Características estruturais das IGFBPs

\begin{tabular}{ll}
\hline Características estruturais & IGFBPs \\
\hline RGD $^{1}$ & IGFBP-1, IGFBP-2 \\
sítios de glicozilação & IGFBP-3, IGFBP-4, IGFBP-5, IGFBP-6 \\
fosforilação da serina & IGFBP-1, IGFBP-3 \\
sinal de localização no núcleo & IGFBP-3, IGFBP-5 \\
\hline
\end{tabular}

${ }^{1}$ seqüência RGD: Arg-Gly-Asp, mediadora da ligação de algumas proteínas à superfície da célula.

Fonte: Rechler \& Clemmons (1998)

Tabela 2. Propriedades físicas e biológicas das IGFBPs ${ }^{1}$

\begin{tabular}{|c|c|c|c|c|c|c|}
\hline Propriedades & IGFBP-1 & IGFBP-2 & IGFBP-3 & IGFBP-4 & IGFBP-5 & IGFBP-6 \\
\hline tamanho $(\mathrm{kDa})$ & 25,3 & 31,4 & 28,7 & 26,0 & 28,6 & 22,8 \\
\hline cisteína (nº̣) & 18 & 18 & 18 & 20 & 18 & 16 \\
\hline sítio ligação heparina & + & + & + & - & + & + \\
\hline preferência de ligante & I e II & $\mathrm{I}<\mathrm{II}$ & I e II & I e II & $\mathrm{I}<$ II & I $<<$ II \\
\hline nível sérico fetal ( $\mu \mathrm{g} / \mathrm{L})$ & 25 & 640 & 1000 & $?$ & $?$ & $?$ \\
\hline nível sérico adulto $(\mu \mathrm{g} / \mathrm{L})$ & 12 & 180 & 3200 & 450 & $?$ & 220 \\
\hline
\end{tabular}

${ }^{1}$ Informações referentes a proteínas de humanos; ? desconhecido; + presente; - ausente; RGD Arg-Gly-Asp.

Fonte: Adaptado de Hossner et al. (1997) 
Todas as seis proteínas de ligação são encontradas na circulação formando complexos binários com os IGFs de peso molecular variando entre 30 a $50 \mathrm{kDa}$. No entanto, a maioria dos IGFs estão presentes ligados a IGFBP-3 formando um complexo binário com aproximadamente $45 \mathrm{kDa}$ ou presente em associação a uma proteína de alto peso molecular a ALS (subunidade ácido lábil, presente em excesso no plasma com peso molecular de aproximadamente $85 \mathrm{kDa}$ ) formando um complexo ternário de 150 kDa (Hossner et al., 1997). Devido ao grande tamanho do complexo, o mesmo é retido no compartimento vascular, prolongando a meia-vida plasmática do IGF-I para aproximadamente 15 horas, comparado a 30 minutos para o complexo binário e a oito minutos para IGF-I livre. A IGFBP-3 também pode se associar com ALS in vitro na ausência de IGF-I, ainda que menos eficientemente (Kelley et al., 1996; Rechler \& Clemmons, 1998).

Todas as três subunidades que formam o complexo ternário são positivamente reguladas pelo hormônio do crescimento $(\mathrm{GH})$ in vivo, e seus níveis na circulação são diretamente correlacionados com o crescimento corporal (Kelley et al., 1996; Harrell et al., 1999; Cordano et al., 2000). As IGFBPs nos tecidos inibem a ação dos fatores de crescimento quando os mesmos estão presentes em excesso, pela formação de um complexo biologicamente inativo que impede a ligação dos IGFs aos receptores. No entanto, em determinadas situações específicas, as proteínas de ligações podem potencializar a ação dos IGFs ou exercer ações independentes dos mesmos (Rechler \& Clemmons, 1998).

Vários fatores regulam a ação das IGFBPs, sendo a proteólise limitada um dos principais. A proteólise limitada de todas as IGFBPs gera um fragmento $\mathrm{N}$ terminal que possui baixa afinidade pelos IGFs, favorecendo sua liberação (Zapf, 1995). Segundo Rechler \& Clemmons (1998), os IGFs são mobilizados do complexo de $150 \mathrm{kDa}$, principalmente por proteólise limitada da IGFBP-3, para formar um fragmento $\mathrm{N}$-terminal de $30 \mathrm{kDa}$ que tem uma afinidade reduzida por 
IGF-I e um fragmento C-terminal o qual permanece associado com o complexo, conforme pode ser observado na Figura 4.

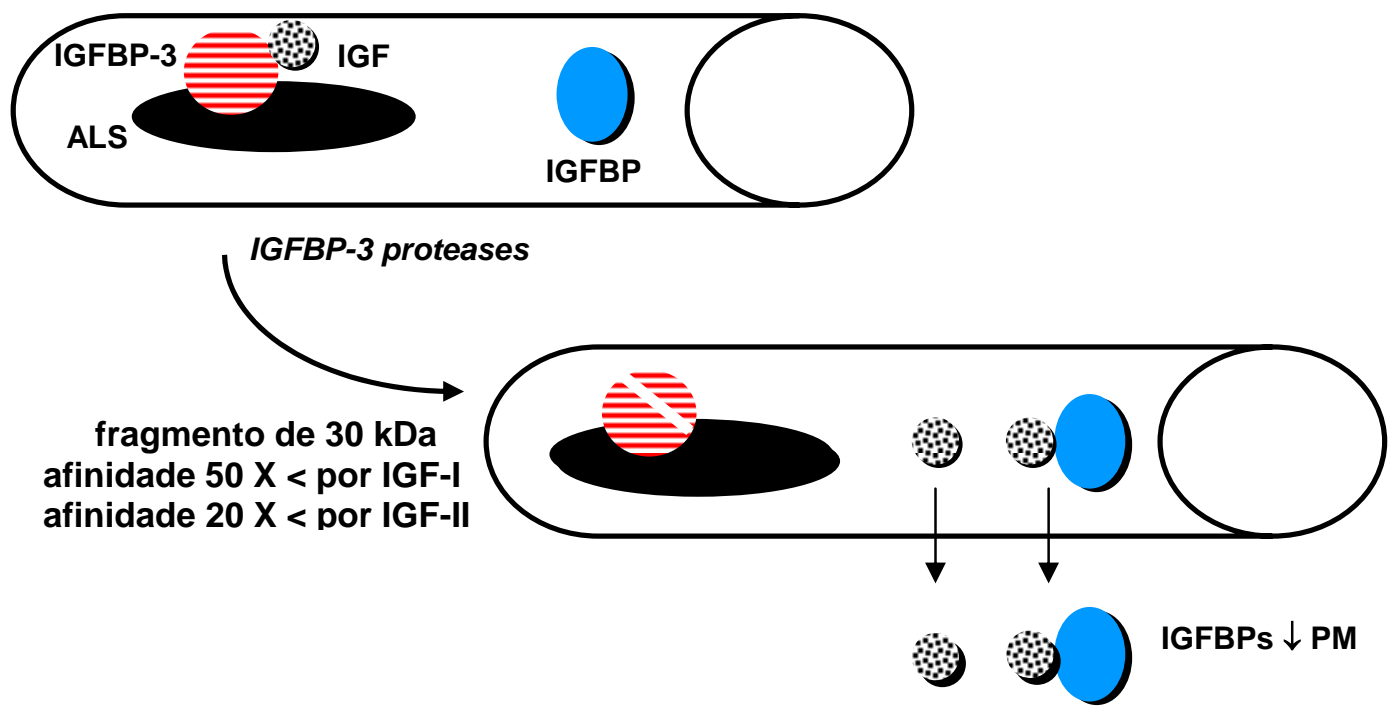

Figura 4 - Mobilização dos IGFs do complexo plasmático de 150 kDa por proteólise limitada da IGFBP-3. A proteólise limitada da IGFBP-3 gera um fragmento de $30 \mathrm{kDa}$ que se liga ao IGF com afinidade reduzida, e um pequeno fragmento que não se liga a IGF. Ambos os fragmentos permanecem associados com o complexo de $150 \mathrm{kDa}$, mas a dissociação do IGF é facilitada. O IGF liberado pode cruzar a barreira endotelial sozinho ou após associação com outras moléculas de IGFBPs de baixo peso molecular ( $\downarrow P M)$

Fonte: Adaptado de Rechler \& Clemmons (1998) 
Rechler \& Clemmons (1998) relatam em sua revisão que três proteases referidas como metaloproteases 1 e 3 e uma serina protease dependente de cálcio contribuem para a atividade proteolítica da IGFBP-3 no soro de camundongos, mas sua relativa importância na ativação de proteases ou proteólise direta da IGFBP-3 ainda não está totalmente elucidada.

Um outro fator regulando a ação das IGFBPs é sua distribuição entre a fase solúvel (meio de cultura ou fluido intersticial) e a matriz extracelular ou superfície celular. Os efeitos inibidores das IGFBPs sobre a ação do IGF-I são associados tipicamente, mas não exclusivamente, com a alta afinidade das formas solúveis. A afinidade da IGFBP-3 e IGFBP-5 por IGF-I é aproximadamente dez vezes menor quando os mesmos estão ligados à superfície da célula ou matriz extracelular. Já a IGFBP-4 age exclusivamente como inibidor da ação de IGF, em parte devido a não associação com a matriz extracelular ou superfície celular (Zapf, 1995; Rechler \& Clemmons, 1998).

Outros mecanismos que promovem uma lenta dissociação e contribuem para potencializar a ação dos IGFs, como a glicozilação, fosforilação e outras modificações, são usados seletivamente pelas IGFBPs. Essas modificações pós-tradução podem representar respostas para mudanças rápidas ou "ajustes finos" que provavelmente são exigidos para funções metabólicas particulares dessas proteínas (Zapf, 1995; Ferry et al., 1999). Segundo Coverley \& Baxter (1997), a fosforilação de algumas proteínas pode determinar inibição ou potencializar a ação dos IGFs. A fosforilação ou defosforilação são mecanismos para a regulação da função das proteínas que proporcionam respostas rápidas e reversíveis em determinadas condições, podendo também influenciar na mobilidade dentro da célula, bem como na estabilidade da proteína. Três das seis IGFBPs (1, 3 e 5) foram encontradas como fosfoproteínas e outras possuem sítios com potencial para fosforilação. A IGFBP-1 quando fosforilada aumenta sua afinidade de ligação pelo IGF em sete vezes e favorece a liberação quando não fosforilada. 
Pesquisas recentes têm demonstrado que apesar das diferentes IGFBPs exibirem padrões de expressão distintos, pode haver redundância suficiente na expressão das mesmas em função de compensar qualquer alteração experimental na expressão de uma simples IGFBP; fato já comprovado ao menos para IGFBP-1 e IGFBP-2 (Rechler \& Clemmons, 1998). A Figura 5 sumariza as localizações fisiológicas das IGFBPs. 


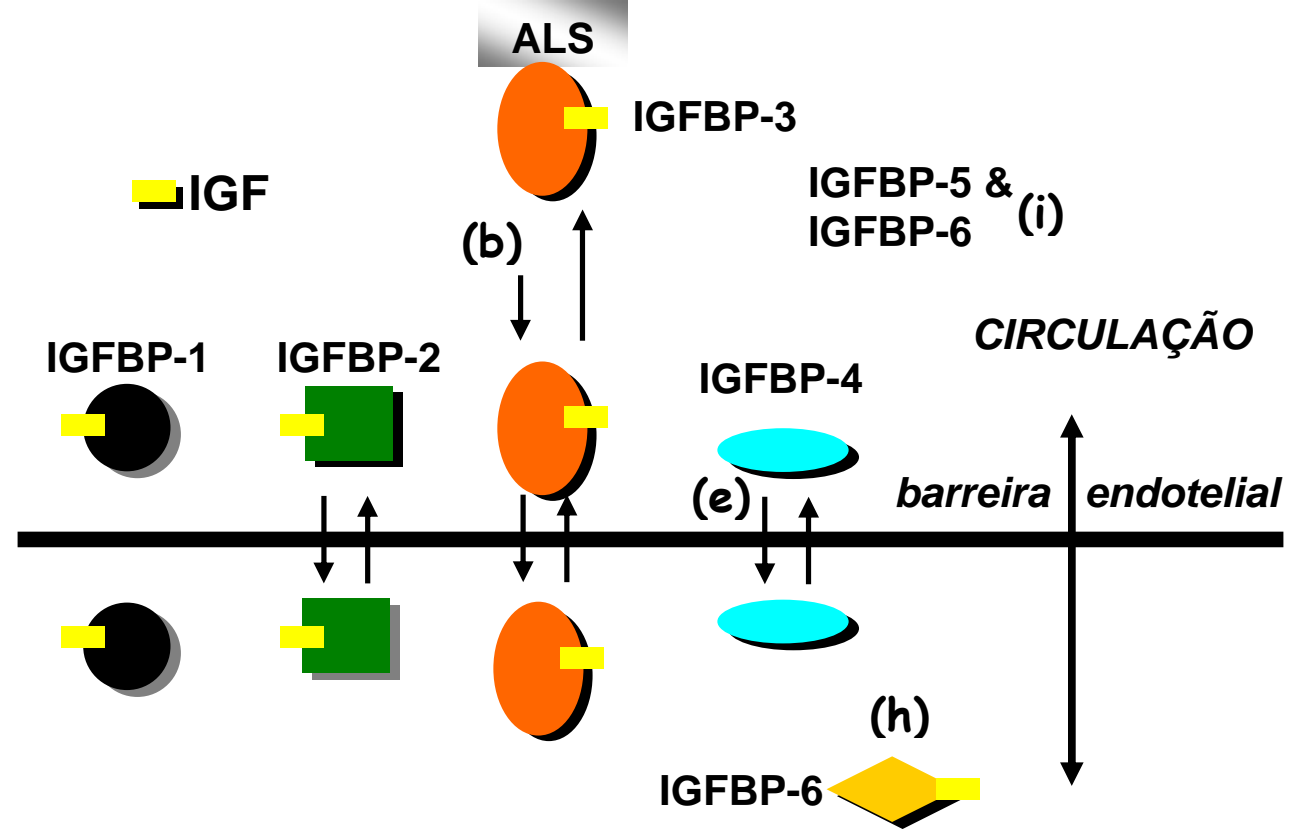

Fluido extracelular

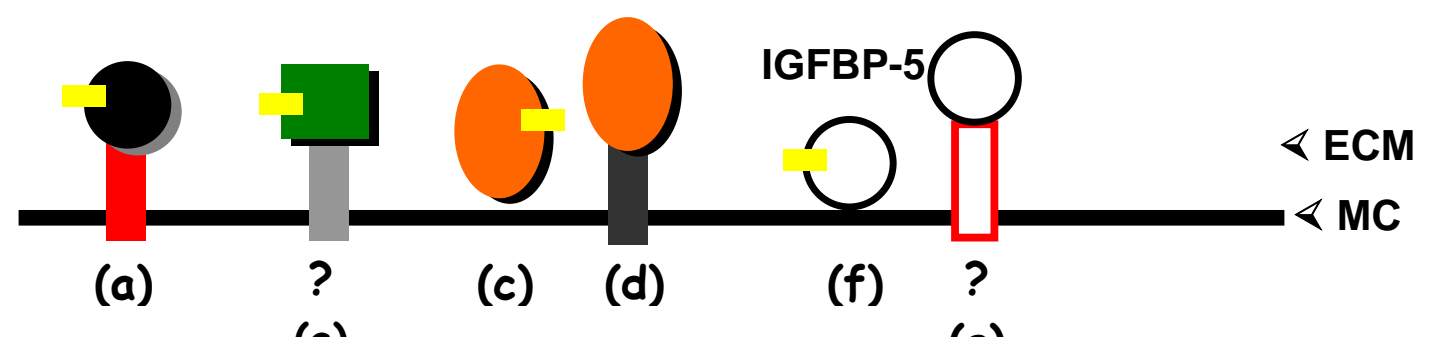

(a)

(g)

Figura 5 - Localizações fisiológicas das IGFBPs. IGFBP-1 e IGFBP-2 estão presentes em todas as localizações podendo se ligar à membrana celular (MC), receptor integrina demonstrado somente para IGFBP-1 (a); IGFBP-3 está presente em altas concentrações na forma de um complexo ternário (b); mas uma forma binária pode cruzar a barreira endotelial, IGFBP-3 pode interagir com a matriz extracelular (ECM) (c); e/ou receptores de membrana (d); IGFBP-4 parece ser solúvel (e); IGFBP-5 interage com a ECM (f); e via receptores de membrana (g); IGFBP-6 é produzida em uma variedade de tecidos (h); IGFBP-5 e 6 são detectadas no soro (i)

Fonte: Adaptado de Kelley et al. (1996) 


\subsection{IGFs nas secreções lácteas}

A produção das secreções lácteas pela mãe para a nutrição do recémnascido é uma das características que definem os mamíferos. A habilidade do crescimento, desenvolvimento e manutenção de uma existência saudável do neonato durante o período de aleitamento é um indicativo da qualidade dessas secreções. A glândula mamária portanto, fornece um nutriente capaz de estimular o desenvolvimento do organismo do animal recém-nascido, principalmente o trato gastrintestinal e o sistema imune, enquanto também melhora o processo digestivo, a absorção de nutrientes e a otimização da microbiota intestinal (Zinn, 1997; Blum \& Hammon, 2000).

Exceto para humanos, lagomorfos e roedores que se beneficiam da passagem via placenta de anticorpos séricos maternos durante 0 desenvolvimento embrionário, outros mamíferos (ungulados), possuem placenta impermeável às imunoglobulinas, nascendo agamaglobulinêmicos ou hipogamaglobulinêmicos. Embora imunocompetentes, os ungulados podem elaborar somente uma resposta imune primária perante um estímulo antigênico durante a vida fetal. Durante as primeiras horas de vida a sobrevivência desses animais depende da ingestão do colostro, o qual fornece ao recém-nascido anticorpos maternos os quais resultam da estimulação antigênica do sistema imunológico da mãe (Salmon, 1999).

As imunoglobulinas são transferidas do sangue materno para as secreções mamárias através de receptores $F c \gamma$ na superfície das células epiteliais. Este transporte é altamente seletivo para IgG e, em ruminantes, específica para $\lg _{1}$, mas não $\lg G_{2}$; o transporte de $\operatorname{lgG}_{1}$ para a glândula mamária é máximo durante a fase de formação do colostro, duas a três semanas antes do parto, e permanece baixo durante a lactação (Watson, 1980).

No bezerro recém-nascido, as imunoglobulinas são absorvidas do colostro para a circulação via um sistema de transporte não-seletivo através do epitélio 
do intestino delgado, sendo a existência de receptores mediando o processo de endocitose sugerida (Staley \& Bush, 1985; Besser \& Gay, 1994; Jochins et al., 1994). Em estudos fisiológicos, observou-se que a absorção de anticorpos em bezerros ocorre principalmente nas regiões média e caudal do intestino delgado (James et al., 1979). Durante o período pós-natal há um curto período em que a mucosa intestinal é altamente permeável às imunoglobulinas, estimado entre 24 e 48 horas de vida nos animais ungulados (Brambell, 1958). Após esse período, o intestino fecha-se para evitar posterior passagem de macromoléculas, incluindo patógenos, que poderiam ser transportados através do epitélio intestinal para a circulação do animal recém-nascido (Lecce \& Morgan, 1962).

Além de anticorpos, o colostro e o leite possuem uma grande variedade de proteínas, peptídeos e esteróides que possuem atividade biológica. Em estudos nos quais a concentração de hormônios e fatores de crescimento têm sido medidos nas secreções lácteas, as maiores concentrações ocorrem nas secreções pré-parto e no colostro (Grosvenor et al., 1993; Odle et al., 1996). O colostro humano contém uma concentração duas a quatro vezes maior de IGF-I em comparação ao leite. O colostro de ratos contém uma concentração maior de IGF-I do que IGF-II, mas as concentrações são semelhantes no leite. Em contraste, o colostro suíno contém maiores quantidades de IGF-II do que IGF-I, apresentando também, concentrações semelhantes no leite (MacDonald, 1999). $\mathrm{Na}$ Tabela 3 podem ser observados níveis de IGF-I e IGF-II no colostro e leite de diferentes espécies. 
Tabela 3. Comparação entre os níveis de IGF-I e IGF-II no colostro e leite de diferentes espécies

\begin{tabular}{|c|c|c|c|c|c|}
\hline \multirow{2}{*}{ Espécie } & \multicolumn{2}{|c|}{ IGF-I (ng/mL) } & \multicolumn{2}{|c|}{ IGF-II (ng/mL) } & \multirow{2}{*}{ Referências } \\
\hline & Colostro & Leite & Colostro & Leite & \\
\hline \multirow[t]{2}{*}{ suína } & $67-357$ & 7 & - & - & Simmen et al. (1988) \\
\hline & $39 \pm 22$ & $11,4 \pm 1,4$ & $82,3 \pm 57,5$ & $16,8 \pm 5,6$ & Donovan et al. (1994) \\
\hline \multirow[t]{4}{*}{ bovina } & $226 \pm 38$ & $24 \pm 2$ & $467 \pm 46$ & $117 \pm 10$ & Malven et al. (1987) \\
\hline & $200-400$ & - & - & - & Simmen et al. (1988) \\
\hline & $234 \pm 27$ & $4,4 \pm 0,9$ & $217 \pm 20$ & $2,9 \pm 1$ & Vega et al. (1991) \\
\hline & $479 \pm 13$ & - & - & - & Vacher et al. (1993) \\
\hline humana & $8-29$ & $5-10$ & - & $160-260$ & Zumkeller (1992) \\
\hline roedor & $20-40$ & $5-21$ & $<1,2$ & $<1$ & Donovan et al. (1991) \\
\hline
\end{tabular}

Vários autores têm verificado altas concentrações de IGF-I no colostro de bovinos com níveis médios variando de 200 a $500 \mathrm{ng} / \mathrm{mL}$, decrescendo para 1-2 $\mathrm{ng} / \mathrm{mL}$ na metade da lactação e aumentando para níveis entre $20-30 \mathrm{ng} / \mathrm{mL}$ ao final da lactação (Simmen et al., 1988; Vega et al., 1991; Donovan et al., 1994; Sejrsen et al., 2001).

Vega et al. (1991) verificaram um aumento de 73\% no nível de IGF-I na corrente sangüínea de vacas nos primeiros dez dias do período seco, com a queda iniciando ao redor de duas semanas pré-parto. A concentração sérica de IGF-II permaneceu constante durante todo o período da amostragem e manteve-se superior à de IGF-I, mas o inverso ocorreu com as secreções mamárias, nas quais as concentrações de IGF-I foram aproximadamente 50\% maiores entre a terceira e a primeira semanas pré-parto. A maior concentração de IGF-I nas secreções lácteas no final do período seco pode se constituir em um indicativo de que IGF-I seja um mediador local do crescimento e desenvolvimento das células epiteliais mamárias (Baumrucker \& Blum, 1993).

Segundo Grosvenor et al. (1993), os IGFs presentes no leite podem ser 
originados por dois mecanismos básicos, transferência do fluido extracelular e por síntese de novo na glândula mamária. Desta última forma duas origens são consideradas, os fibroblastos e as células epiteliais do tecido mamário, sendo a primeira hipótese de origem mais aceita. Campbell et al. (1991) verificaram que explantes de tecido mamário sintetizaram e secretaram IGF-I e IGFBPs. No entanto, a baixa produção que ocorre nessas células parece não ser suficiente para o massivo acúmulo de IGF que ocorre durante o período de formação do colostro, mas poderia explicar os baixos níveis de IGF que ocorrem no leite.

Considerando que o processo de transferência de substâncias da corrente sangüínea para a glândula mamária ocorre predominantemente no período préparto, receptores específicos para IGF-I e IGF-II foram caracterizados e identificados nos tecidos mamários de bovinos o que poderia permitir a transferência da circulação materna para a secreção láctea (Donovan et al., 1994).

De acordo com Hadsell et al. (1990), a transferência da corrente sangüínea para a glândula mamária seria através de endocitose mediada por receptores, processo análogo àquele demonstrado para a transferência de imunoglobulinas no período pré-parto (Brandon et al., 1971). Hadsell et al. (1990) também verificaram um aumento do número de receptores associado ao parto o que poderia modular a atividade ou o transporte de IGF no tecido mamário. Devido a similaridade na dinâmica de flutuação para IGF-I e IgG em bovinos, esse seria um mecanismo bastante razoável para explicar o acúmulo de IGF-I no colostro e no leite (Vega et al., 1991).

Outro mecanismo de transferência para as secreções lácteas seria a passagem entre as células epitelias. Essas células possuem "pontos de escape" na zônula de oclusão, porém esse mecanismo não manteria o alto gradiente de concentração que existe para IGF-I e outros peptídeos e hormônios (Baumrucker \& Blum, 1993).

A concentração dos fatores de crescimento presentes no colostro pode 
variar, também, em função de características de produção do animal. Campbell \& Baumrucker (1989) quantificaram mudanças temporais da concentração de IGF-I no colostro e leite bovinos. As vacas exibiram baixas concentrações de IGF-I e produziram menos leite na primeira lactação comparada com lactações subseqüentes, sugerindo que a concentração de IGF-I no colostro está relacionada a produção de leite. Já Kerr et al. (1991), comparando vacas de alta e baixa produção, verificaram que a produção leiteira não refletiu diretamente a flutuação sérica de IGF-I.

O hormônio do crescimento $(\mathrm{GH})$ é o mais abundante dentre os hormônios secretados pela hipófise anterior. Sua molécula (um polipeptídeo de 191 aminoácidos e $22 \mathrm{kDa}$ ) é importante não somente por sua ação no crescimento, mas também agindo no metabolismo de lipídios e carboidratos. O hormônio de crescimento tem habilidade de alterar o metabolismo do tecido adiposo, alterando sua sensibilidade a outros hormônios como insulina e epinefrina (Burton et al., 1994).

O avanço no conhecimento desse hormônio tem permitido uma conexão com outras moléculas relacionadas ao seu metabolismo, sendo a supremacia dos efeitos relacionados a hipertrofia e proliferação celular primariamente mediados pelo IGF-I. Muita atenção tem sido dada a habilidade da somatotropina bovina recombinante (rbST) em estimular a produção de leite em rebanhos leiteiros. Esse fenômeno é considerado biologicamante interessante, bem como economicamente significante para a indústria leiteira (Burton et al., 1994). Entretanto, os detalhes bioquímicos da ação do rbST na glândula mamária não são totalmente compreendidos. Aumento do substrato ou aumento do número de células epiteliais são necessários para o aumento de produção. Entretanto, bST não interage diretamente com as células epiteliais, seu mecanismo de ação se dá de forma indireta influenciando o crescimento e atividade da glândula mamária. A natureza pulsátil do hormônio do crescimento é outra característica que dificulta a correlação de níveis de $\mathrm{GH}$ a características 
de crescimento. Já os níveis de IGF-I são relativamente constantes e refletem o status de GH do animal (Cohick, 1998).

Glimm et al. (1988) verificaram que, em condições normais, IGF-I está presente no tecido mamário associado a elementos do estroma. Após tratamento com rbST, IGF-I imunoreativo foi também detectado no estroma, mas com maior evidência no epitélio alveolar. As mudanças observadas na distribuição do IGF-I no tecido mamário correspondem ao aumento do IGF-I circulante. Já Hadsell et al. (1993), demonstraram que o aumento de IGF-I circulante pelo tratamento com rbST no período seco, aumentou também a transferência de IGF-I para as secreções pré-parto. A massa total de IGF-I secretada aumentou em três vezes e a concentração no colostro em $40 \%$. Portanto, aumentando-se o IGF-I circulante durante o período pré-parto há uma transferência seletiva de IGF-I para as secreções da glândula mamária.

Weber et al. (2000), trabalhando com vacas leiteiras recebendo rbST aliado ao consumo de altos níveis de energia, verificaram um aumento de $46 \%$ no conteúdo de IGF-I em extratos mamários em relação aos animais controle. Os autores verificaram também, que os efeitos do tratamento com somatotropina e o nível de energia ingerido podem ser mediados por alterações na síntese local das proteínas de ligação. 


\subsection{IGFs e o desenvolvimento do recém-nascido}

A presença de altas concentrações de fatores de crescimento nas secreções lácteas tem importante significado. Algumas evidências são a base do conceito de que os IGFs estão relacionados com crescimento, diferenciação e galactopoiese da glândula mamária. Por sua vez, a glândula mamária seria responsável pelos hormônios e fatores de crescimento que complementariam o crescimento e o desenvolvimento do recém-nascido, exercendo seus efeitos primariamente no trato gastrintestinal (Grosvenor et al., 1993; Donovan et al., 1994; Blum \& Hammon, 2000).

Olanrewaju et al. (1996) demonstraram que a concentração de IGF-I no conteúdo gástrico de ratos recém-nascidos é reflexo da concentração desse fator no leite materno e pode ser suficientemente alta para afetar a proliferação e diferenciação celulares. Sejrsen et al. (2001) relatam em sua revisão que adicionando-se quantidades crescentes de colostro (2 a 10\%) a uma cultura de células epiteliais há um aumento de três a quatro vezes na síntese de DNA quando comparado ao nível basal. O efeito mitogênico do colostro no trato gastrintestinal, entretanto, cai rapidamente dentro das primeiras semanas pósparto.

Nos animais recém-nascidos os fatores de crescimento atuam diretamente nas células intestinais. Para que os IGFs possam exercer sua ação biológica devem interagir com receptores específicos de membrana. Morgan et al. (1996), estudando a expressão de receptores de IGF-I na mucosa do intestino delgado de leitões, verificaram que houve um declínio na expressão dos receptores da mucosa entre o nascimento e a desmama. Schober et al. (1991), também estudando a presença de receptores para IGF-I no intestino delgado de leitões recém-nascidos, verificaram que a ligação específica de $\left[{ }^{125} \mid\right] \mid G F-I$ às membranas ao nascimento foi quase duas vezes maior em comparação às 
membranas de animais com três e cinco dias de idade, sendo essa mudança relacionada principalmente à mudanças no número de receptores.

Uma hipótese muito estudada é que os IGFs das secreções lácteas poderiam atuar em outros tecidos além do trato intestinal. Para que essa hipótese seja verdadeira, os IGFs deveriam sobreviver à digestão, serem absorvidos e então transportados para o tecido alvo. Baumrucker et al. (1994), fornecendo IGF-I humano recombinante (rhIGF-I) para bezerros, $750 \mathrm{ng} / \mathrm{mL}$ em refeições que correspondiam a $5 \%$ do peso vivo por sete dias após o nascimento, verificaram que nos animais suplementados houve um aumento na incorporação de $\left[{ }^{3} \mathrm{H}\right]$ timidina pelas células intestinais, indicando maior síntese de DNA, bem como um aumento dos receptores do tipo I, o que poderia estar relacionado a um aumento do IGF-I na circulação do recém-nascido. Já Vacher et al. (1995), administrando rhIGF-I diretamente em alças intestinais de bezerros recém-nascidos, verificaram somente pequeno aumento na concentração sérica de IGF-I, sugerindo que a ligação do IGF-I às proteínas de ligação pode evitar sua absorção e ação sistêmica. Resultados semelhantes foram obtidos por Donovan et al. (1997), os quais verificaram que ${ }^{125}$ I-rhIGF-I administrado oralmente para leitões recém-nascidos não contribui significativamente para o aumento do IGF-I circulante e também por Philipps et al. (1995), que fornecendo IGF-I e IGF-II marcados radioativamente a ratos recém-nascidos, verificaram que os fatores de crescimento podiam ser recolhidos em suas formas biologicamente ativas 30 minutos após a ingestão no lume do trato gastrintestinal, mas não em tecidos de órgãos distantes do intestino.

Breier et al. (1988) verificaram que alterações na concentração plasmática de IGF-I em bezerros foi dependente de mudanças relacionadas a nutrição e também a idade do animal. No nascimento os animais apresentaram média de 40,3 ng/mL, havendo uma queda na concentração plasmática para 23,8 ng/mL até a $5^{\text {a }}$ semana. Os autores verificaram também, baixa concentração de receptores somatotrópicos no fígado dos recém-nascidos, o que indica que $\mathrm{GH}$ 
não tem influência dominante na produção de IGF-I no início da vida. Resultado semelhante foi encontrado por Harrell et al. (1999), os quais verificaram que leitões recebendo somatotropina exógena apresentavam um padrão de resposta dependente da idade, sendo que o tratamento somente resultou em aumentos limitados de IGF-I no início da vida do animal.

Houle et al. (1997), trabalhando com leitões privados de colostro e suplementados com rhIGF-I administrado oralmente $(200 \mu \mathrm{g} / \mathrm{kg} / \mathrm{dia})$, verificaram que esses animais não apresentaram diferenças quanto ao peso corporal e de órgãos quando comparados aos animais não suplementados aos sete e aos 14 dias de vida. A administração oral de IGF-I, mesmo em doses suprafisiológicas, também não influenciou as concentrações circulantes dos mesmos. Entretanto, os animais suplementados apresentaram um aumento da atividade das dissacaridases intestinais e diferenças morfométricas da mucosa intestinal aos 14 dias de idade. Ma \& Xu (1997), trabalhando com ratos suplementados diariamente com rhIGF-I oral $(1 \mu \mathrm{g} / \mathrm{dia})$, do nascimento até três dias de idade, também encontraram maior atividade das dissacaridases intestinais, o que sugere um efeito na maturação do epitélio absortivo.

Hardon et al. (1997) verificaram que o fornecimento de colostro para bezerros recém-nascidos nas primeiras 24 horas de vida, em comparação ao fornecimento aos dois dias de vida, resultou em maior eficiência de absorção das imunoglobulinas e aumento da concentração plasmática de glucose, albumina, insulina e IGF-I, o que indica estímulo de processos anabólicos. Os autores ressaltam também, que o aumento nos níveis circulantes de IGF-I provavelmente não seria explicado pela absorção dessa molécula do colostro, nem por estímulo de hormônios como GH e insulina, e sim por outros nutrientes encontrados no colostro, especialmente ácidos graxos e aminoácidos, que levariam a um aumento da produção endógena de IGF-I.

Resultados semelhantes foram encontrados por Kühne et al. (2000), trabalhando com bezerros ingerindo altas quantidades de colostro ou sucedâneo 
nos três primeiros dias de vida. Os autores verificaram que a ingestão de diferentes quantidades de colostro influencia parcialmente o metabolismo de gorduras e proteínas, provavelmente em função do nível de ingestão de energia e proteína.

Já Zanker et al. (2001), investigaram as conseqüências do atraso do fornecimento do colostro para bezerros recém-nascidos. Os autores verificaram que animais que ingeriram a primeira refeição de colostro entre 24 e 25 horas após o nascimento apresentaram níveis baixos de proteína total plasmática e globulinas durante 30 dias e de IGF-I por sete dias. Resultados semelhantes foram obtidos por Pauletti et al. (2002), os quais observaram que animais com falha de transferência de imunidade passiva (concentração sérica de lgG <10 $\mathrm{mg} / \mathrm{mL}$ ) apresentaram baixas concentrações de IgG sérica no primeiro mês de vida. No entanto Zanker et al. (2001), observaram que os são capazes de compensar a deficiência nutricional da ausência do colostro durante as primeiras horas de vida, não havendo prejuízos quanto a parâmetros hematológicos, metabólicos e endócrinos.

No epitélio do intestino delgado dos animais as células são originadas nas criptas e continuamente migram para o topo das vilosidades. Entre o nascimento e a desmama, dois períodos críticos para a adaptação gastrintestinal, esta dinâmica é essencial para o processo de crescimento intestinal e está sob controle de fatores intrínsecos, como a genética do animal, sendo também influenciada por fatores extrínsecos, como hormônios e fatores de crescimento presentes em altas quantidades nas secreções lácteas. No entanto, informações referentes a esses períodos relacionadas a proliferação de células intestinais são escassas no que diz respeito a espécies animais de grande porte e morfogênese intestinal precoce, um grupo que inclui a maioria dos animais domésticos de importância agronômica (Odle et al., 1996).

Attaix \& Meslin (1991) estudaram mudanças na morfologia intestinal e renovação celular em ovelhas com uma, cinco e oito semanas de idade, após 
injeção com timidina $\left[{ }^{3} \mathrm{H}\right]$. A maior taxa de migração de enterócitos ocorreu nas ovelhas com uma semana de idade $(4,4$ a $9,7 \mu \mathrm{m} / \mathrm{h})$. Os autores verificaram um aumento gradual na profundidade da cripta com a idade, especialmente no intestino delgado proximal, ainda que a altura das vilosidades se apresentasse significativamente menor na região distal.

Bühler et al. (1998), fornecendo colostro por três dias em duas refeições diárias, suplementação oral de IGF-I ou injeções de rbST por sete dias para bezerros recém-nascidos, verificaram que em comparação ao grupo controle, animais que ingeriram colostro somente na primeira refeição, o colostro por período prolongado aumentou significativamente $(P<0,01)$ a área e altura das vilosidades do intestino delgado após uma semana de tratamento, sendo que o IGF-I fornecido oralmente não influenciou a morfologia do intestino e as injeções de rbST reduziram as variáveis relacionadas à morfometria da mucosa intestinal. Os autores sugerem que o fornecimento prolongado de colostro pode influenciar a morfologia da mucosa intestinal e, consequentemente aumentar a capacidade absortiva do intestino.

Já Blättler et al. (2001), fornecendo colostro por um período de sete dias demonstraram que quantidades suplementares de colostro estimularam o desenvolvimento das vilosidades na região proximal do intestino delgado, sendo que nenhuma alteração foi verificada na porção distal. No entanto, os animais que receberam colostro por um período prolongado apresentaram menores taxas de proliferação celular na mucosa intestinal. Esses resultados indicam que, ainda que haja um aumento no tamanho das vilosidades intestinais, a densidade celular não é alterada, sugerindo que a ingestão de colostro maximizada pode levar a um aumento da sobrevivência das células epiteliais do intestino e a uma redução na taxa de turnover das mesmas, possivelmente mediado por fatores de crescimento como IGF-I. Resultados semelhantes foram obtidos por Rauprich et al. (2000). 
Os IGFs são degradados no intestino e a atividade de degradação é dependente da idade do animal, do segmento intestinal e da ligação dos IGFs às IGFBPs. De acordo com Kruse et al. (1983), apenas durante algumas horas após o nascimento existem condições ideais para a absorção de macromoléculas pelos bezerros, tais como: pequena produção de $\mathrm{HCl}$ no estômago; atividade mínima da pepsina gástrica; presença de um fator inibidor de tripsina no colostro e baixa atividade proteolítica da mucosa intestinal. Philipps et al. (1995), trabalhando com ratos lactentes ingerindo leite contendo ${ }^{125}$ I-IGF-I e ${ }^{125}$ I IGF-II, verificaram que os IGFs permanecem estáveis e em suas formas ativas no trato intestinal por um período de até 30 minutos após administração oral. Fellah et al. (2001) estudaram a relação da atividade de enzimas proteolíticas intestinais com a degradação dos IGFs. Os autores encontraram que a atividade enzimática da quimiotripsina, tripsina e elastase progrediu da região proximal do intestino delgado para a região distal. A quimiotripsina exibiu a mais alta atividade de degradação no lume intestinal em relação aos IGFs, seguida pela elastase. 


\section{MATERIAL E MÉTODOS}

\subsection{Animais e tratamentos}

O trabalho experimental de campo foi realizado na Fazenda Agrindus, município de Descalvado, Estado de São Paulo. As análises laboratoriais foram realizadas nos laboratórios de Anatomia e Fisiologia Animal (LAFA), Histologia Animal, Nutrição e Crescimento Animal (LANA) e Bromatologia do Departamento de Zootecnia USP/ESALQ, e também no Núcleo de Apoio à Microscopia Eletrônica NAP/MEPA, sob supervisão do Prof. Dr. Elliot Watanabe Kitajima. As análises de IGF-I foram realizadas no Laboratório Fleury, município de São Paulo, sob supervisão do Prof. Dr. José Gilberto Henriques Vieira, Diretor Técnico Científico do Setor de Endocrinologia.

Foram utilizadas 42 vacas da raça Holandesa, em gestação, multíparas, com prenhez de macho confirmada e os respectivos bezerros recém-nascidos. As vacas foram distribuídas ao acaso em dois grupos de 21 animais. $\mathrm{O}$ grupo tratado recebeu $500 \mathrm{mg}$ de somatotropina bovina recombinante (rbST- Boostin- 
Coopers) aplicados na fossa ísquio retal a partir de 35 dias pré-parto, em intervalos de 14 dias, e os animais que formaram o grupo controle receberam injeções $(2 \mathrm{~mL}$ ) de vitamina $\mathrm{E}$ (Monovin-E acetato de $\mathrm{DL}$ - $\alpha$-tocoferol $2 \mathrm{mg} / 20 \mathrm{~mL}$ ) aplicadas na fossa ísquio retal, nas mesmas datas de aplicação do hormônio. O fornecimento de vitamina $E$ para o grupo controle foi em função do hormônio de crescimento adotado (rbST-Boostin-Coopers) ter como excipiente a vitamina E.

Os bezerros recém-nascidos foram distribuídos ao acaso, em um arranjo fatorial $2 \times 3$, correspondendo ao tratamento das mães (rbST ou controle) e às datas de abate. $O$ grupo 1 foi abatido ao nascimento, o grupo 2 foi abatido aos dois dias de idade e o grupo 3 foi abatido aos sete dias de idade. Assim, o experimento contou com sete bezerros dentro de cada tratamento (rbST ou controle) para cada data de abate.

\subsection{Manejo dos animais}

Durante o período experimental as vacas permaneceram em piquetes de Coast-cross e consumiram ração balanceada ad libitum. Amostras das rações das vacas no período pré-parto foram coletadas periodicamente para análise bromatológica. Durante esse período o escore corporal dos animais foi acompanhado semanalmente. A metodologia utilizada para esta avaliação foi sugerida por Smith et al. (1982), que classifica a condição corporal dos animais em uma escala numérica de 1 a 5 , correspondente a animais tidos como muito magros ou muito obesos, respectivamente. A unidade de escore da condição corporal utilizada nesta avaliação foi 0,5.

No final do período pré-parto as vacas eram separadas e alocadas em baias individuais tendo à sua disposição ração e água ad libitum. Os animais foram monitorados continuamente para assegurar a separação do bezerro da mãe e o controle da ingestão do colostro. 
Após o parto, os bezerros foram separados imediatamente das mães, pesados, identificados e alocados em baias onde receberam o colostro da respectiva mãe ( $5 \%$ do peso vivo) na primeira hora de vida com a utilização de mamadeira. Os animais que apresentaram dificuldade em mamar receberam o colostro através de sonda esofagiana. Após a ingestão do colostro os animais passaram a receber quatro litros de leite da respectiva mãe em duas refeições diárias.

O experimento não interferiu no manejo sanitário do rebanho, cumprindose o calendário de vacinação pré-parto das vacas. Os bezerros também foram monitorados quanto a distúrbios gastrintestinais e à doenças do trato respiratório, não havendo nenhum registro durante o experimento.

\subsection{Coleta das amostras}

Foram coletadas amostras de sangue das mães semanalmente com início 35 dias pré-parto até o parto, retiradas da veia mamária (aproximadamente $10 \mathrm{~mL}$ ). Amostras de sangue dos bezerros foram coletadas antes da ingestão do colostro e diariamente até a data de abate, retiradas da veia jugular (aproximadamente $10 \mathrm{~mL}$ ). Após centrifugação o soro resultante de cada amostra foi transferido para três frascos devidamente identificados e mantidos a uma temperatura de $-20^{\circ} \mathrm{C}$.

Amostras do colostro e das secreções lácteas foram coletadas diariamente até sete dias pós-parto, sendo cada amostra transferida para três frascos devidamente identificados e mantidos a uma temperatura de $-20^{\circ} \mathrm{C}$.

Nas datas de abate, os animais eram pesados, anestesiados e exsangüinados, sendo o intestino delgado isolado e coletadas amostras do duodeno, jejuno e íleo para análise histológica. Foram também, retirados e pesados os seguintes órgãos: trato gastrintestinal, pulmões, coração, rins, 
fígado e baço.

\subsection{Análise das amostras}

\subsubsection{Microscopia óptica}

Imediatamente após a retirada do trato gastrintestinal, a porção do intestino delgado, entre o esfíncter pilórico e a válvula ileocecal, era removida e dividida em cinco segmentos de aproximadamente cinco centímetros de comprimento. Segmento 1 - duodeno, segmento 2 - jejuno cranial, segmento 3 - jejuno médio, segmento 4 - jejuno caudal e segmento 5 - íleo.

Em seguida, as amostras eram abertas em papel filtro e esticadas em placas de petri com o auxílio de alfinetes, procedendo-se uma lavagem da superfície do tecido com solução salina 0,9\%. Os tecidos eram então fixados por imersão em solução de paraformaldeído 4\% em tampão fosfato $0,1 \mathrm{M}$ a pH 7,2 por duas horas. Após essa etapa inicial, o tecido era lavado em tampão fosfato 0,1M a pH 7,2 procedendo-se três lavagens de 20 minutos. O tecido era cortado novamente em fragmentos de aproximadamente $5 \times 5 \mathrm{~mm}$, recolocados em tampão e mantidos a uma temperatura de $4^{\circ} \mathrm{C}$. Posteriormente, o tecido sofreu desidratação lenta pela passagem em banhos de concentrações crescentes de etanol, 30\% até 100\%, procedendo-se uma lavagem de dez minutos em cada concentração e três lavagens de dez minutos em etanol 100\%.

A etapa seguinte consistiu da pré-infiltração com uma solução de resina glicol metacrilato diluída (JB-4, Polyscience Inc.) em etanol 100\% na proporção 1:1, na qual o tecido permaneceu por quatro horas. Após a pré-infiltração, os tecidos passaram para a resina pura e em seguida foi realizada a inclusão do material em histomoldes, mergulhando-se os tecidos em resina plástica a temperatura ambiente. 
Os blocos, contendo os tecidos incluídos, foram seccionados por navalha de aço em um micrótomo Leica RM 2045, obtendo-se cortes de $5 \mu \mathrm{m}$ de espessura. As lâminas foram montadas com no mínimo dez cortes não seqüenciais (Bühler et al., 1998). Os cortes eram estirados em água, colocados em lâminas, corados com hematoxilina e eosina (HE) e montados entre lâmina e lamínula com resina sintética.

\subsubsection{Análise morfométrica}

A análise morfométrica foi realizada utilizando-se estereologia. Os cortes histológicos foram analisados utilizando-se um sistema de análise de imagens (Axio-Zeiss) acoplado a um microscópio Zeiss, em um aumento constante (10X) para comparação dos resultados obtidos (VanGinneken et al., 2002). Para cada segmento de cada animal foram analisados 20 campos.

A análise estereológica para determinação do volume parcial $(\mathrm{VV})$ ocupado pela mucosa do duodeno, jejuno cranial, jejuno médio, jejuno caudal e íleo foi realizada por meio de sobreposição de um sistema teste do tipo ciclóide às imagens dos cortes. Esse sistema teste (Figura 6) conta com 35 arcos ciclóides e 70 pontos teste, fotocopiado em uma transparência e sobreposto sobre cada campo da secção selecionada.

Para serem utilizados os métodos estereológicos, os cortes analisados devem ser isotrópicos, no entanto a mucosa do intestino delgado não é um meio isotrópico, pois possui estruturas de orientação definida. Para esse tipo de estrutura, Baddeley et al. (1986) propuseram o método de estereologia de cortes verticais, no qual os cortes são perpendiculares à uma superfície "horizontal", representada por um plano existente na estrutura em estudo. No presente estudo, foi considerado como plano "horizontal" o limite entre a mucosa e a submucosa. 
O volume parcial da mucosa foi expresso como porcentagem e foi obtido pelo número de pontos teste que caiam sobre a superfície da mucosa e o número total de pontos na grade. O volume parcial é dado pela equação:

$$
\operatorname{Vv}(\%)=\sum P(\text { MUCOSA }) / \sum P(\text { VOLUME REFERENCIAL }) \cdot 100
$$

Em que:

$\sum \boldsymbol{P}(\mathbf{M U c o s} A)=$ número de pontos do sistema teste caindo sobre a camada específica;

$\sum \boldsymbol{P}($ VOLUME REFERENCIAL $)=$ número total de pontos na grade. 


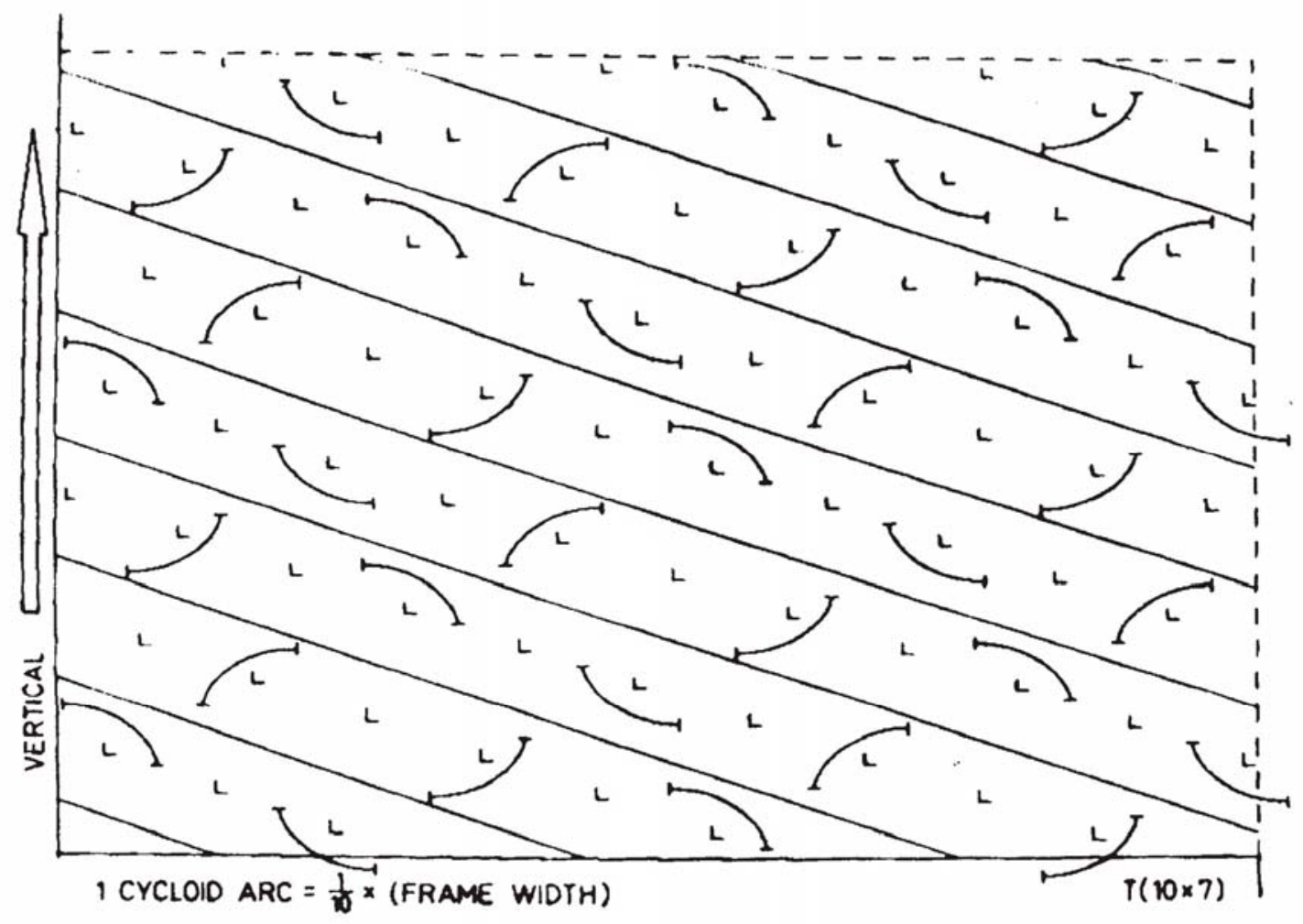

Figura 6 - Representação esquemática do sistema teste de arcos ciclóides Fonte: Baddeley et al. (1986) 


\subsubsection{Análise da imunoglobulina G - IgG}

A fração IgG sérica das vacas e dos bezerros foi quantificada pelo método de imunodifusão radial descrita por Mancini et al. (1965). A fração IgG do colostro e secreções lácteas foi quantificada pelo método de imunodifusão radial descrita por Mancini et al. (1965) modificado por Besser et al. (1985). A técnica se baseia na leitura do diâmetro formado pela reação do anticorpo da amostra com o anti-lgG em meio de ágar, comparando-se com diâmetros padrões préestabelecidos. Para a construção das curvas padrão foi utilizado IgG obtida da Sigma (Sigma Chemical Company). O ágar foi preparado com concentração de $1,2 \%$ de agarose em tampão TRIS-HCl $(\mathrm{pH} \mathrm{8,0)} \mathrm{com} \mathrm{anti-IgG} \mathrm{Sigma.} \mathrm{Além} \mathrm{das}$ placas para as curvas padrão, todas as placas continham duas concentrações padrão para avaliação da variação entre as placas. As amostras nas quais as repetições variaram acima de $5 \%$ foram novamente analisadas. As placas eram incubadas em câmaras úmidas por 24 horas a uma temperatura de $5^{\circ} \mathrm{C}$. Os diâmetros de precipitação foram medidos e registrados em milímetros.

As equações obtidas seguiam o modelo abaixo:

$$
Y=a X+b
$$

Em que:

$$
\begin{aligned}
& Y=\log \text { concentração de } \mathrm{lg} \mathrm{G} \mathrm{em} \mathrm{mg} / \mathrm{mL} ; \\
& \mathbf{X}=\text { diâmetro da reação em } \mathrm{mm} .
\end{aligned}
$$




\subsubsection{Análise da proteína total - PT}

A quantificação da proteína total sérica foi determinada pelo método de biureto, segundo Reinhold (1953). Misturou-se $20 \mu \mathrm{L}$ da amostra do soro com $980 \mu \mathrm{L}$ de $\mathrm{NaOH}(0,75 \mathrm{~N})$ e $200 \mu \mathrm{L}$ de biureto reativo. Após 20 minutos de reação procedeu-se a leitura da absorbância em espectrofotômetro UV-1601 PC SHIMADZU com comprimento de onda ajustado em $545 \mathrm{~nm}$. Para cada bateria de amostras, estabeleceu-se uma curva padrão que relacionava concentrações conhecidas de proteína (albumina bovina - Sigma Chemical Company) a valores de absorbância obtidos das amostras. As amostras foram analisadas em duplicata, sendo o valor médio utilizado para se obter as concentrações de proteína sérica em g/100mL de soro.

\subsubsection{Análise do fator de crescimento semelhante à insulina-I - IGF-I}

As concentrações de IGF-I no soro das vacas e dos bezerros, no colostro e nas secreções lácteas foram quantificadas por ensaio imunoradiométrico pósextração utilizando-se o kit DSL-5600 (Diagnostic Systems Laboratories, Inc.). O colostro e as secreções lácteas sofreram centrifugação prévia de 30 minutos a 13000 g. Misturou-se $50 \mu \mathrm{L}$ da amostra a $200 \mu \mathrm{L}$ da solução de extração (etanol ácido) incubando-se por 30 minutos em temperatura ambiente. Em seguida, as amostras foram centrifugadas a $13000 \mathrm{~g}$ por três minutos a $25^{\circ} \mathrm{C}$. Após a centrifugação, transferiu-se $100 \mu \mathrm{L}$ do sobrenadante e adicionou-se $500 \mu \mathrm{L}$ de solução neutralizante (solução tampão). Para cada bateria de amostras estabeleceu-se uma curva padrão, a qual relacionava concentrações conhecidas de IGF-I às concentrações das amostras, adicionando-se também, dois controles, contendo alta e baixa concentração de IGF-I, que serviam para a validação do ensaio. Adicionava-se $50 \mu \mathrm{L}$ dos padrões, controles e amostras 
neutralizadas aos tubos marcados contendo anti-IGF-I. Imediatamente adicionava-se $200 \mu \mathrm{L}$ de anti-IGF-I $\left[{ }^{125}\right.$ I] e incubava-se por 3 horas em temperatura ambiente em um shaker a 180 rpm. Após a incubação os tubos eram decantados e lavados três vezes com $3 \mathrm{~mL}$ de água destilada cada tubo. Após essa operação cada tubo era seco individualmente e colocado para contagem em um contador gama (Automatic Gamma Counter 1470, Wizard TM Wallac). As amostras foram analisadas em duplicata, sendo o valor médio utilizado para se obter as concentrações de IGF-I em ng/mL.

\subsubsection{Análise de acidos graxos não-esterificados - AGNE}

As concentrações séricas de AGNE foram determinadas através do método enzimático colorimétrico, utilizando-se o kit NEFAc (Wako 994-75409E). Para cada bateria de amostras, estabeleceu-se uma curva padrão que relacionava concentrações conhecidas de AGNE às concentrações das amostras. A leitura da absorbância foi realizada em espectrofotômetro UV-1601 PC SHIMADZU com comprimento de onda ajustado em $545 \mathrm{~nm}$. As amostras foram analisadas em duplicata, sendo o valor médio utilizado para se obter as concentrações de AGNE $\mu \mathrm{mol} / \mathrm{L}$. 


\subsubsection{Análises bromatológicas}

As amostras de ração total foram secas em estufas de ventilação forçada (55-60 ${ }^{\circ} \mathrm{C}$ ) por 72 horas para determinação de matéria seca (MS), de acordo com A.O.A.C. (1975). As amostras pré-secas foram moídas em moinhos tipo Wiley providos de peneira de malha de $1 \mathrm{~mm}$ de diâmetro e acondicionadas em plásticos devidamente identificados.

As amostras foram analisadas para matéria seca $\left(105^{\circ} \mathrm{C}\right)$, matéria mineral, proteína bruta e fibra bruta de acordo com A.O.A.C. (1975), e a fibra em detergente neutro (FDN) e fibra em detergente ácido (FDA) de acordo com Van Soest et al. (1991).

$\mathrm{Na}$ Tabela 4 encontram-se as proporções de ingredientes utilizados e a composição bromatológica da ração total consumida pelas vacas durante o período experimental, com base na matéria seca. 
Tabela 4. Proporções de ingredientes utilizados e composição bromatológica da ração total consumida pelas vacas durante o período de tratamento

\begin{tabular}{lc}
\hline \multicolumn{1}{c}{ Ingredientes } & Proporções \\
\cline { 2 - 2 } & $\% \mathrm{MS}$ \\
\hline Silagem de milho & 61,6 \\
Feno de tifton & 7,0 \\
Caroço de algodão & 17,0 \\
Grãos de milho moído & 4,27 \\
Polpa cítrica & 8,4 \\
570 ca nutron (suplemento mineral) & 1,7 \\
Vitamina AD & 0,015 \\
Vitamina E & 0,015 \\
& \\
\hline \multicolumn{1}{c}{ Composição } & Média ${ }^{1}$ \\
\hline Matéria Seca & 44,0 \\
Proteína Bruta & 15,2 \\
Fibra Bruta & 19,7 \\
Extrato Etéreo & 3,0 \\
Matéria Mineral & 6,1 \\
Extrativo Não Nitrogenado & 56,0 \\
N.D.T. (estimado) & 68,0 \\
Fibra Detergente Neutro & 44,0 \\
Fibra Detergente Ácido & 22,8 \\
\hline Resulados analicosexprossos & \\
\hline
\end{tabular}

${ }^{1}$ Resultados analíticos expressos em 100\% de matéria seca (MS).

NDT = nutrientes digestíveis totais, calculado de acordo com Kearl (1982). 


\subsubsection{Delineamento experimental e análise estatística}

O delineamento experimental adotado foi inteiramente casualizado em parcelas subdivididas no tempo, sendo o efeito do tratamento hormonal com somatotropina ou tratamento controle com vitamina $E$ aplicado às parcelas e as medidas repetidas no tempo consideradas como subparcelas. O modelo utilizado para análise foi:

$$
y_{i j k}=\mu+T_{i}+P_{j}+l_{i j}+e_{i j k}
$$

$\mathrm{y}_{\mathrm{ijk}}=$ observação do indivíduo $\mathrm{k}$, pertencente ao tratamento i e ao período j;

$\mu=$ média geral;

$\mathrm{T}_{\mathrm{i}}=$ efeito do i-ésimo tratamento;

$P_{\mathrm{j}}=$ efeito do j-ésimo período;

$\mathrm{I}_{\mathrm{ij}}=$ efeito da interação do i-ésimo tratamento com o j-ésimo período;

$\mathrm{e}_{\mathrm{ijk}}=$ erro aleatório associado a cada observação $\mathrm{ijk}$, suposto normalmente distribuído e independente, com média zero e variância $\sigma^{2}$.

Os dados foram analisados através do procedimento PROC MIXED do programa SAS (1991), em que a condição corporal das vacas, as variáveis séricas das vacas e dos bezerros e as secreções lácteas foram submetidas a análise de variância para tal delineamento. Para a avaliação de diferenças entre médias foram efetuados contrastes entre pares de médias utilizando-se o método de Tukey. Para todas as análises utilizou-se o nível de significância de $5 \%(P<0,05)$.

Foi utilizada a transformação das variáveis séricas IgG (raiz quadrada) e IGF-I (log na base 10) referentes às vacas e aos bezerros, pois não foi atendida a suposição de linearidade feita em análises empregando-se os modelos lineares.

Análises de correlação, Pearson e Spearman, foram realizadas para 
verificar associações de interesse entre as variáveis séricas.

Para as variáveis peso corporal, peso dos órgãos e volume parcial $(\mathrm{Vv})$ da mucosa dos cinco segmentos do intestino delgado dos bezerros, considerou-se um arranjo fatorial $2 \mathrm{X} 3$, tendo como efeitos principais os tratamentos rbST ou controle e as três datas de abate. Para a avaliação de diferenças entre médias foram efetuados contrastes entre pares de médias utilizando-se o método de Tukey. Para todas as análises utilizou-se o nível de significância de 5\% $(\mathrm{P}<0,05)$. 


\section{RESULTADOS E DISCUSSÃO}

\subsection{Escore corporal e ácidos graxos não-esterificados}

O escore corporal médio semanal dos animais distribuídos nos dois grupos em função do tratamento hormonal é apresentado na Tabela 5.

Tabela 5. Escore corporal médio das vacas durante o período de tratamento e na data de parição

\begin{tabular}{ccccccccccc}
\hline & \multicolumn{9}{c}{$\begin{array}{c}\text { Período de Tratamento } \\
\text { (semanas) }\end{array}$} \\
\cline { 2 - 10 } Trat $^{1}$ & $\mathbf{1}^{\underline{\mathbf{a}}}$ & $\mathbf{2}^{\mathbf{a}}$ & $\mathbf{3}^{\mathbf{a}}$ & $\mathbf{4}^{\underline{\mathbf{a}}}$ & $\mathbf{5}^{\mathbf{a}}$ & Parto & $\begin{array}{c}\text { Média } \\
\text { Geral }\end{array}$ & Trat & Período \\
\hline Controle & 3,56 & 3,48 & 3,46 & 3,40 & 3,31 & 3,30 & 3,42 & 0,67 & 0,62 \\
ST & 3,35 & 3,46 & 3,61 & 3,52 & 3,50 & 3,40 & 3,47 & & \\
Média Período & 3,45 & 3,47 & 3,53 & 3,46 & 3,40 & 3,36 & & & \\
DP $^{3}$ & 0,37 & 0,37 & 0,33 & 0,38 & 0,44 & 0,33 & & & \\
\hline
\end{tabular}

${ }^{1}$ Trat: Controle - tratamento com vitamina E, ST - tratamento com rbST (somatotropina bovina recombinante); ${ }^{2} \mathrm{P}=$ probabilidade; ${ }^{3} \mathrm{DP}=$ desvio padrão. 
O escore corporal dos animais do início do tratamento até o parto não diferiu entre os grupos ( $P>0,05)$. Não foram observadas também, mudanças do escore corporal ao longo do período experimental $(P>0,05)$, apresentando 0 mesmo um valor médio de 3,45 ao longo do período. O valor médio encontrado no presente trabalho está de acordo com o proposto por Quigley \& Drewry (1998) para vacas durante o período seco. Os autores propõem que o objetivo do manejo durante os dois últimos meses de gestação seria proporcionar às vacas uma dieta para atingir uma condição corporal adequada com escore 3,5, satisfazendo as exigências nutricionais e minimizando distúrbios metabólicos. Putnam et al. (1999), avaliando o efeito da suplementação de proteína em dois níveis, 13 e 17\% de proteína bruta na matéria seca, aliada ao uso de rbST sobre o escore corporal de vacas leiteiras no período final de gestação, observaram resultados semelhantes ao presente trabalho em que o nível médio de proteína bruta utilizado foi de 15\% (Tabela 4). Os autores não encontraram diferenças quanto ao escore corporal dos animais tratados em relação aos animais controle, sendo o valor médio observado de 3,5. Vallimont et al. (2001), também trabalhando com suplementação de rbST com início 28 dias pré-parto, obtiveram resultados semelhantes.

Hadsell et al. (1993), trabalhando com vacas secas tratadas com hormônio de crescimento com início oito semanas pré-parto, não observaram diferenças significativas quanto a alterações de peso dos animais em relação as vacas controle que receberam injeções de solução salina. Os autores só encontraram diferenças significativas quanto a perda de peso em animais submetidos a restrição alimentar no mesmo período. Gulay et al. (2003), trabalhando com vacas leiteiras recebendo baixa dosagem de rbST durante o período pré-parto (10,2 mg rbST/dia; $28 \pm 3$ dias antes da data prevista de parição), também não observaram efeito significativo do tratamento no ganho de peso dos animais ou na condição corporal. 
As principais atividades do hormônio de crescimento in vivo são o aumento da lipólise, gluconeogênese, mamogênese e galactopoiese. A combinação da diminuição da lipogênese e o aumento do uso das reservas corporais durante o tratamento com somatotropina podem resultar em elevações crônicas e perdas irreversíveis de ácidos graxos não esterificados (AGNE) (Burton et al., 1994).

As concentrações médias de AGNE ( $\mu \mathrm{mol} / \mathrm{L})$ dos animais distribuídos nos dois grupos em função do tratamento hormonal são apresentadas na Tabela 6 e Figura 7.

Tabela 6. Concentrações séricas de ácidos graxos não-esterificados ( $\mu \mathrm{mol} / \mathrm{L}$ ) durante o período de tratamento e na data de parição

\begin{tabular}{cccccccc}
\hline & \multicolumn{9}{c}{$\begin{array}{c}\text { Período de Tratamento } \\
\text { (semanas) }\end{array}$} & & & & $\mathbf{P}^{2}$ \\
\cline { 2 - 8 } Trat $^{1}$ & $\mathbf{1}^{\mathbf{a}}$ & $\mathbf{2}^{\mathbf{a}}$ & $\mathbf{4}^{\underline{\mathbf{a}}}$ & Parto & $\begin{array}{c}\text { Média } \\
\text { Geral }\end{array}$ & Trat & Período \\
\hline Controle & 458,36 & 497,63 & 490,73 & 599,82 & 511,63 & 0,95 & 0,01 \\
ST & 459,40 & 425,35 & 501,30 & 631,80 & 504,46 & & \\
Média Período & $458,88^{\mathrm{A}}$ & $461,49^{\mathrm{A}}$ & $496,01^{\mathrm{A}}$ & $615,81^{\mathrm{B}}$ & & & \\
DP $^{3}$ & 86,27 & 100,12 & 118,47 & 137,17 & & & \\
\hline
\end{tabular}

\footnotetext{
${ }^{\mathrm{AB}}$ Médias seguidas de letras diferentes na mesma linha diferem entre si pelo teste de Tukey $(P<0,05)$.

${ }^{1}$ Trat: Controle - tratamento com vitamina E, ST - tratamento com rbST (somatotropina bovina recombinante); ${ }^{2} \mathrm{P}=$ probabilidade $;{ }^{3} \mathrm{DP}=$ desvio padrão.
} 


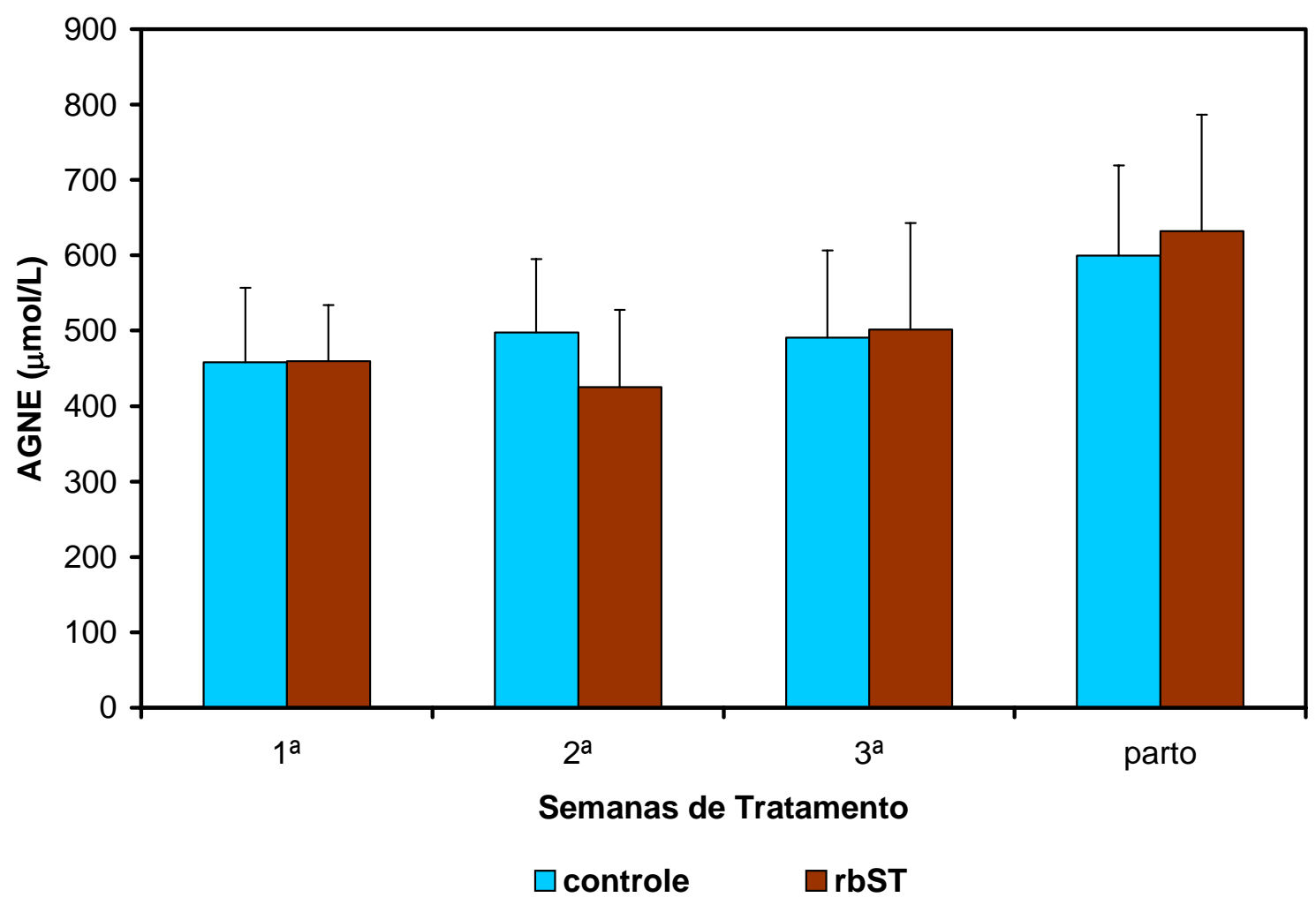

Figura 7 - Concentrações séricas de ácidos graxos não-esterificados (média \pm desvio padrão) durante o período de tratamento e na data de parição

As concentrações séricas de AGNE encontradas ao longo do período experimental não diferiram entre os tratamentos $(P>0,05)$, encontrando-se somente efeito significativo de período $(P<0,05)$. As concentrações médias de AGNE em todos os períodos e no parto, independente do tratamento, foi superior à encontrada por Ronge \& Blum (1988), os quais observaram concentração média de AGNE em vacas durante o período pré-parto de 331 $\mu \mathrm{mol} / \mathrm{L}$.

Putnam et al. (1999), suplementando vacas com rbST durante o período seco com início 28 dias pré-parto encontraram valores de AGNE semelhantes ao presente trabalho, com níveis médios de $600 \mu \mathrm{mol} / \mathrm{L}$ na semana que antecedeu o parto. Como no presente estudo, apesar das altas concentrações 
de AGNE, os autores também não observaram diferenças em função do tratamento no escore corporal dos animais ao longo do período experimental. Resultados semelhantes foram obtidos por Simmons et al. (1994). Já Vallimont et al. (2001), também trabalhando com vacas que receberam somatotropina com início 28 dias pré-parto, observaram valores muito inferiores de AGNE aos acima citados, com valor médio de 134,3 $\mu \mathrm{mol} / \mathrm{L}$.

O tratamento com rbST pode levar a uma mobilização de AGNE, no entanto diferentes respostas em relação a administração do hormônio durante o período pré-parto podem estar diretamente relacionadas ao estado nutricional em que os animais se encontram. Vacas em balanço energético negativo apresentam um aumento na perda de AGNE, indicando um aumento na mobilização de reservas corporais, sem alteração na lipogênese. Já em vacas em balanço energético positivo, a maior parte dos efeitos da somatotropina estão relacionados à redução na síntese de gorduras (Bauman et al., 1988; Lanna et al., 1995). Entretanto, Gallo \& Block (1990) observaram que a administração de rbST resultou em um persistente aumento na concentração sérica de $A G N E$, independente do balanço energético em que o animal se encontrava antes do início do tratamento. Já Vallimont et al. (2001), demonstraram uma interessante relação entre ingestão de matéria seca e a concentração de AGNE. Os autores verificaram que a cada $1 \mathrm{~kg}$ de decréscimo na ingestão de matéria seca havia um acréscimo na concentração de AGNE de $38 \mu \mathrm{mol} / \mathrm{L}$. 


\subsection{IGF-I, IgG e PT séricos das vacas}

As médias originais (média \pm desvio padrão) das variáveis séricas que sofreram transformação, IGF-I e IgG, são apresentadas no Apêndice 1.

Considerando-se que o início do tratamento se dava em função da data prevista de parição, testou-se como covariável dias entre o início do tratamento até o parto para todas as variáveis séricas estudadas, entretanto a mesma não se mostrou significativa $(P>0,05)$ para nenhuma delas, não sendo então considerada no modelo. A média de dias entre o início do tratamento até o parto foi de $29,75 \pm 7,48$ dias.

As médias das concentrações de IGF-I ( $\mathrm{ng} / \mathrm{mL}$ ) são apresentadas na Tabela 7. As concentrações séricas de IGF-I diferiram entre os tratamentos, entre os períodos, encontrando-se, também, interação significativa entre tratamento e período $(P<0,05)$, o que indica diferenças no comportamento da variável em função do tratamento nas várias determinações. 
Tabela 7. Concentrações séricas de IGF-I (ng/mL) das vacas durante o período de tratamento e na data de parição

\begin{tabular}{|c|c|c|c|c|c|c|c|c|c|c|}
\hline \multirow[b]{2}{*}{ Trat $^{1}$} & \multicolumn{5}{|c|}{$\begin{array}{c}\text { Período de Tratamento } \\
\text { (semanas) }\end{array}$} & \multirow[b]{2}{*}{ Parto } & & \multicolumn{3}{|c|}{$\mathbf{P}^{2}$} \\
\hline & $1^{\underline{a}}$ & $2^{\underline{a}}$ & $3^{\mathrm{a}}$ & $4^{\mathrm{a}}$ & $5^{\underline{a}}$ & & $\begin{array}{l}\text { Média } \\
\text { Geral }\end{array}$ & Trat & Período & $\begin{array}{c}\text { Trat X } \\
\text { Período }\end{array}$ \\
\hline Controle & $82,75^{A}$ & $80,00^{\mathrm{aA}}$ & $63,67^{A}$ & $32,91^{\mathrm{aB}}$ & $36,14^{\mathrm{B}}$ & $13,19^{C}$ & 43,33 & \multirow{2}{*}{0,02} & \multirow{2}{*}{0,01} & \multirow{2}{*}{0,01} \\
\hline ST & $71,66^{\mathrm{A}}$ & $203,89^{\mathrm{bB}}$ & $80,42^{\mathrm{A}}$ & $121,28^{\mathrm{bC}}$ & $35,97^{\mathrm{D}}$ & $16,95^{\mathrm{D}}$ & 66,56 & & & \\
\hline Média Período & 77,02 & 127,70 & 71,56 & 63,18 & 36,05 & 14,95 & & & & \\
\hline
\end{tabular}

${ }^{a b}$ Médias seguidas de letras diferentes na mesma coluna diferem entre si pelo teste $F(P<0,05)$.

${ }^{A B C D}$ Médias seguidas de letras diferentes na mesma linha diferem entre si pelo teste de Tukey $(P<0,05)$.

${ }^{1}$ Trat: Controle - tratamento com vitamina E, ST - tratamento com rbST (somatotropina bovina recombinante); ${ }^{2} \mathrm{P}=$ probabilidade. 
No presente trabalho, os níveis séricos de IGF-I na primeira semana de tratamento foram semelhantes para o grupo controle e para o grupo tratado com rbST, 82,75 e 71,66 ng/mL, respectivamente, indicando homogeneidade na concentração sérica dessa variável no início do tratamento. A média observada no presente trabalho para o período foi inferior a encontrada por Vega et al. (1991), os quais avaliando vacas com período seco de aproximadamente $60 \pm 5$ dias, encontraram o pico de concentração de IGF-I sérico com valor de 163 $\mathrm{ng} / \mathrm{mL}$ aos 34 dias pré-parto.

Os níveis circulantes de IGF-I variaram consideravelmente entre o início do período experimental e o parto nos dois grupos. Para os animais do grupo controle foi observada uma amplitude de variação entre o valor máximo e o valor mínimo de $84 \%$, com valores de $82,75 \mathrm{ng} / \mathrm{mL}$ para a primeira semana e $13,19 \mathrm{ng} / \mathrm{mL}$ no parto. Até a terceira semana de tratamento esses animais não apresentaram diferenças significativas nas concentrações séricas de IGF-I, sendo observada queda a partir da quarta semana. Ronge \& Blum (1988), avaliando vacas leiteiras durante o período pré-parto, encontraram concentração sérica de IGF-I duas semanas pré-parto em torno de $40 \mathrm{ng} / \mathrm{mL}$. Valores próximos foram encontrados no presente trabalho para o grupo controle em que as concentrações nas duas últimas semanas que antecederam o parto foram 32,91 e $36,14 \mathrm{ng} / \mathrm{mL}$, respectivamente.

A amplitude de variação encontrada para o grupo tratado com rbST foi de $92 \%$, superior a encontrada para os animais controle, com valores máximo e mínimo variando entre $203,89 \mathrm{ng} / \mathrm{mL}$ para a segunda semana e $16,95 \mathrm{ng} / \mathrm{mL}$ no parto. O grupo tratado apresentou níveis superiores $(P<0,05)$ de IGF-I em relação ao grupo controle na segunda e na quarta semanas após o início do tratamento em resposta às aplicações do rbST (203,89 vs. $80,00 \mathrm{ng} / \mathrm{mL}$ e 121,28 vs. $32,91 \mathrm{ng} / \mathrm{mL}$, respectivamente). 
A elevação dos níveis circulantes de IGF-I no início do período seco e o declínio nas últimas semanas que antecedem o parto têm sido descritos por vários autores (Ronge \& Blum, 1988; Vega et al., 1991; Burton et al., 1994; Sharma, et al., 1994). A administração de rbST utilizada nesse período para elevar os níveis circulantes de IGF-I e, conseqüentemente alterar a produção leiteira no período pós-parto, também tem sido estudada (Stelwagen et al., 1992; Stelwagen et al., 1993; Putnam et al., 1999; Vallimont et al., 2001).

Hadsell et al. (1993), trabalhando com animais que receberam rbST durante o período pré-parto, também observaram diferenças significativas na concentração de IGF-I em relação aos animais controle na segunda e quarta semanas após o início do tratamento, com valores de 279,53 e 191,53 ng/mL, respectivamente. Os valores encontrados pelos autores foram superiores aos encontrados neste estudo para o grupo tratado com rbST, entretanto com início do período experimental sete semanas pré-parto, fase em que os animais ainda podem apresentar elevação dos níveis circulantes de IGF-I, diferentemente do que ocorreu no presente experimento, em que o tratamento iniciou cinco semanas pré-parto, período em que as concentrações séricas de IGF-I tendem a iniciar a queda até a data de parição. Os autores também observaram valores mais altos de IGF-I na data do parto em relação ao presente trabalho, foram verificadas concentrações de 67,77 e $25,77 \mathrm{ng} / \mathrm{mL}$ para animais tratados com rbST e controle, respectivamente.

Já Vega et al. (1991), acompanhando a flutuação sérica de IGF-I em vacas leiteiras que não receberam qualquer tratamento hormonal ou restrição alimentar durante o período seco, relataram que as maiores mudanças no IGF-I sérico ocorreram quatro dias antes e três dias após o parto, com uma redução de $70 \%$ nos níveis circulantes. Os autores observaram concentrações séricas de IGF-I cinco dias pré-parto variando de 24 a $81 \mathrm{ng} / \mathrm{mL}$. 
Comportamento semelhante foi observado no presente trabalho para os animais do grupo controle, em que os níveis de IGF-I das duas últimas semanas em relação ao parto apresentaram queda significativa $(P<0,05)$ de aproximadamente $60 \%$ do IGF-I sérico. Já os animais do grupo tratado com somatotropina não apresentaram diferenças entre a última semana de tratamento e a data do parto. Esse fato pode estar relacionado a proximidade da última data de aplicação do hormônio e a data do parto. As médias observadas no parto, 16,95 e 13,19 ng/mL para animais tratados com rbST e para o grupo controle, respectivamente, não diferiram entre si $(P>0,05)$.

Os resultados encontrados no presente experimento refletem um aumento da concentração de IGF-I em resposta às aplicações do rbST, uma vez que a supremacia dos efeitos relacionados a hipertrofia e a proliferação celular, em resposta à administração de rbST, são primariamente mediados pelo IGF-I (Glimm et al., 1988; Prosser et al., 1989; Burton et al., 1994). No entanto, o aumento na concentração sérica de IGF-I em resposta à administração do hormônio de crescimento é dependente também, do plano de nutrição, incluindo porcentagem de energia e proteína na dieta. Animais bem nutridos respondem ao tratamento com rbST elevando os níveis séricos de IGF-I, enquanto animais com alguma restrição exibem pouco ou nenhum aumento nas concentrações de IGF-I (Breier et al., 1988).

As médias das concentrações de $\lg G(\mathrm{mg} / \mathrm{mL})$ são apresentadas na Tabela 8. As concentrações séricas de IgG não diferiram entre os tratamentos $(P>0,05)$. Verificou-se efeito significativo somente de período $(P<0,05)$, com queda significativa de $20 \%$ nos níveis séricos circulantes entre a primeira semana do período experimental e o parto, 36,90 vs. $29,11 \mathrm{mg} / \mathrm{mL}$, respectivamente. 
Tabela 8. Concentrações séricas de $\operatorname{lgG}(\mathrm{mg} / \mathrm{mL})$ das vacas durante o período de tratamento e na data de parição

\begin{tabular}{|c|c|c|c|c|c|c|c|c|c|c|}
\hline \multirow[b]{2}{*}{ Trat $^{1}$} & \multicolumn{5}{|c|}{$\begin{array}{c}\text { Período de Tratamento } \\
\text { (semanas) }\end{array}$} & \multirow[b]{2}{*}{ Parto } & & \multicolumn{3}{|c|}{$\mathbf{P}^{2}$} \\
\hline & $1^{\underline{a}}$ & $2^{\mathrm{a}}$ & $3^{\mathrm{a}}$ & $4^{-\mathrm{a}}$ & $5^{\mathrm{a}}$ & & $\begin{array}{l}\text { Média } \\
\text { Geral }\end{array}$ & Trat & Período & $\begin{array}{c}\text { Trat X } \\
\text { Período }\end{array}$ \\
\hline Controle & 35,13 & 35,40 & 34,76 & 31,40 & 32,98 & 27,74 & 32,84 & 025 & 001 & \\
\hline ST & 38,71 & 38,16 & 36,10 & 34,28 & 35,81 & 30,52 & 35,54 & $\checkmark,<v$ & & \\
\hline Média Período & $36,90^{A}$ & $36,77^{\mathrm{A}}$ & $35,42^{\mathrm{A}}$ & $32,82^{\mathrm{B}}$ & $34,38^{A B}$ & $29,11^{C}$ & & & & \\
\hline
\end{tabular}

${ }^{A B C}$ Médias seguidas de letras diferentes na mesma linha diferem entre si pelo teste de Tukey $(P<0,05)$.

${ }^{1}$ Trat: Controle - tratamento com vitamina E, ST - tratamento com rbST (somatotropina bovina recombinante); ${ }^{2} \mathrm{P}=$ probabilidade. 
Os resultados observados no presente estudo estão de acordo com trabalhos clássicos que relatam queda de 10 a 30\% nos níveis de imunoglobulinas totais do soro sangüíneo em várias espécies associadas ao parto (Larson \& Kendal, 1957; Smith, 1959; Dixon et al., 1961; Schmidt, 1971; Jeffcott, 1972; Sasaki et al., 1976). Já Brandon et al. (1971), analisando as subclasses de IgG, observaram uma redução na concentração sérica de $\lg _{1}$ em torno de $50 \%$ entre a terceira semana pré-parto e o parto, ao passo que os níveis de $\lg _{2}$ mantiveram-se inalterados.

Levando-se em consideração as altas concentrações da variável na primeira semana do período experimental (35,13 e 38,71 mg/mL, grupo controle e rbST, respectivamente), observa-se que os animais iniciaram o tratamento em uma boa condição imunológica, refletindo um manejo adequado no período préparto. Apesar da elevada concentração inicial, a queda na concentração sérica de IgG entre o início do período experimental e o parto foi de $8 \mathrm{mg} / \mathrm{mL}$, semelhante a queda observada por outros estudos com nível médio de anticorpos séricos variando entre 20 a $25 \mathrm{mg} / \mathrm{mL}$ no último mês antes do parto (Brandon et al., 1971; Sasaki et al., 1976; Hadsell et al., 1993).

Aliado ao fato da boa condição imunológica dos animais, sabe-se que vacas multíparas apresentam queda mais tardia e menos pronunciada de IgG sérica no período pré-parto. Esse fato foi observado por Willians \& Millar (1979), os quais estudando a flutuação sérica de $\operatorname{lgG}_{1}, \operatorname{lgG}_{2}$ e $\operatorname{lgM}$ em vacas primíparas e multíparas observaram que os níveis de $\operatorname{lgG}_{1}$ nas primíparas diminuíram significativamente entre a quarta semana pré-parto e o parto, ainda que em vacas a partir da segunda parição essa queda se apresentasse mais tardia e mais gradual.

A queda na concentração sérica de IgG durante o período pré-parto está associada à remoção ativa desses anticorpos pela glândula mamária (Sasaki et al., 1976). Dixon et al. (1961), Brandon et al. (1971) e Foley \& Otterby (1978) afirmaram que, durante as três últimas semanas pré-parto, 500 a 700 gramas 
de imunoglobulinas são transferidas do sangue para as secreções lácteas.

Assim como para IgG, a remoção ativa de IGF-I da corrente sangüínea pela glândula mamária no período pré-parto é sugerida como um dos mecanismos envolvidos no declínio do IGF-I circulante (Prosser et al. 1989; Kerr, 1991; Vega et al., 1991). Entretanto, a concentração sérica de IGF-I após o parto permanece baixa por algumas semanas, fato esse relacionado a um decréscimo no balanço energético que altera os níveis circulantes de IGF-I (Vega et al., 1991). Já a hipogamaglobulinemia pré-parto não é influenciada pelo balanço energético do animal, sendo prontamente corrigida, com a concentração de anticorpos materna retornando a níveis normais nas primeiras semanas após o parto, entre 20 e $30 \mathrm{mg} / \mathrm{mL}$ (Schmidt, 1971; Sasaki et al., 1976).

Além do efeito direto da administração de rbST nos níveis circulantes de IGF-I, alguns trabalhos têm observado efeitos indiretos como alterações no sistema imune do animal. Burton et al. (1991a), trabalhando com vacas que receberam rbST na quarta e quinta semanas de lactação e Hadsell et al. (1993), trabalhando com o fornecimento de rbST durante o período pré-parto, demonstraram um aumento na concentração sérica de IgG, fato não observado no presente trabalho em que a IgG sérica no período pré-parto não diferiu entre os tratamentos $(P>0,05)$. Burton et al. (1991b), avaliando a resposta de vacas lactantes tratadas com rbST na proliferação de linfócitos sangüíneos, como um parâmetro imunológico para avaliação do efeito do hormônio no sistema imune, concluíram que uma maior proliferação das células linfocitárias exige um tratamento a longo prazo e que as maiores concentrações de IGF-I sérico não estariam relacionadas à resposta proliferativa dos linfócitos.

Por outro lado, Burton et al. (1992), trabalhando nas mesmas condições experimentais, não observaram efeito do rbST na resposta humoral do sistema imune. Assim, ainda não se tem definido o efeito do rbST sobre as concentrações de IgG e tão pouco o possível mecanismo envolvido. 
As médias das concentrações de PT ( $\mathrm{g} / 100 \mathrm{~mL})$ são apresentadas na Tabela 9. As concentrações séricas de PT não diferiram entre os tratamentos $(P>0,05)$ durante o período pré-parto, encontrando-se efeito significativo de período $(P<0,05)$ e interação significativa entre tratamento e período $(P<0,05)$.

Nos dois grupos foram observadas altas concentrações de PT sérica na primeira semana do período experimental, 9,40 $\pm 0,79$ e 9,05 $\pm 1,06 \mathrm{~g} / 100 \mathrm{~mL}$, para o grupo controle e rbST, respectivamente, em parte reflexo dos elevados níveis de lgG sérica observados nos animais no mesmo período.

Os animais do tratamento controle apresentaram queda significativa $(P<0,05)$ de $18 \%$ na concentração sérica de PT do início do tratamento até o parto $(9,40$ e $7,74 \mathrm{~g} / 100 \mathrm{~mL}$, respectivamente). Já os animais que receberam rbST apresentaram uma menor queda $(9 \%, \mathrm{P}<0,05)$ na concentração de PT sérica no mesmo período (9,05 e 8,21 g/100mL, respectivamente). Essa menor amplitude de variação encontrada nos animais do grupo rbST está relacionada ao fato de não se ter observado diferenças entre os níveis de PT a partir da quarta semana de tratamento, já os animais do grupo controle apresentaram diferenças significativas no mesmo período. Ronge \& Blum (1988) verificaram também, queda significativa da concentração da variável próxima a data de parição, entretanto com média inferior à encontrada no presente estudo, de $6,67 \mathrm{~g} / 100 \mathrm{~mL}$. 
Tabela 9. Concentrações séricas de PT $(\mathrm{g} / 100 \mathrm{~mL})$ das vacas durante o período de tratamento e na data de parição

\begin{tabular}{|c|c|c|c|c|c|c|c|c|c|c|}
\hline \multirow[b]{2}{*}{ Trat $^{1}$} & \multicolumn{5}{|c|}{$\begin{array}{c}\text { Período de Tratamento } \\
\text { (semanas) }\end{array}$} & \multirow[b]{2}{*}{ Parto } & \multirow[b]{2}{*}{$\begin{array}{l}\text { Média } \\
\text { Geral }\end{array}$} & \multicolumn{3}{|c|}{$\mathrm{P}^{2}$} \\
\hline & $1^{\underline{a}}$ & $2^{\underline{a}}$ & $3^{\underline{a}}$ & $4^{\underline{a}}$ & $5^{\underline{a}}$ & & & Trat & Período & $\begin{array}{c}\text { Trat X } \\
\text { Período }\end{array}$ \\
\hline Controle & $9,40^{\mathrm{A}}$ & $9,33^{A}$ & $8,84^{B}$ & $8,37^{C}$ & $8,09^{C D}$ & $7,74^{\mathrm{D}}$ & 8,63 & \multirow{2}{*}{0,90} & \multirow{2}{*}{0,01} & \multirow{2}{*}{0,01} \\
\hline ST & $9,05^{\mathrm{A}}$ & $8,80^{A B}$ & $8,64^{\mathrm{BC}}$ & $8,35^{\mathrm{CD}}$ & $8,54^{\mathrm{BD}}$ & $8,21^{\mathrm{D}}$ & 8,60 & & & \\
\hline Média Período & 9,22 & 9,06 & 8,74 & 8,36 & 8,32 & 7,98 & & & & \\
\hline$D P^{3}$ & 0,64 & 0,68 & 0,81 & 0,89 & 0,58 & 0,74 & & & & \\
\hline
\end{tabular}


Em contraste ao presente estudo, em que os níveis de PT séricos não foram influenciados pelo tratamento hormonal, Rosi \& Pinotti (2002), trabalhando com vacas da raça Holandesa tratadas com rbST durante a lactação, verificaram um aumento significativo $(P<0,05)$ na concentração sérica de proteína total entre a segunda e quinta semanas após o início do tratamento, variando de 7,89 para $8,14 \mathrm{mg} / 100 \mathrm{~mL}$. Apesar dos autores não terem avaliado a concentração sérica de IgG, o aumento da concentração de proteína total pode estar correlacionado a um aumento da concentração da fração IgG sérica, como observado por alguns estudos já mencionados anteriormente (Burton et al., 1991a; Hadsell et al., 1993), fato não observado no presente trabalho em que as concentrações séricas de lgG não diferiram entre os tratamentos.

As variáveis PT e imunoglobulinas séricas foram significativamente correlacionadas $(P<0,05)$, considerando-se o período experimental total, com valor de $r=0,27$ independente do tratamento; e com valor de $r=0,42$ e $r=0,21$, para o grupo controle e rbST, respectivamente, não sendo significativa $(P>0,05)$ entre as variáveis séricas somente no parto para ambos tratamentos. Já a variável IGF-I não mostrou correlação significativa com PT $(P>0,05)$, considerando-se o período experimental total e o parto independente dos tratamentos, bem como para os tratamentos.

A concentração de todas as variáveis séricas variou significativamente em função do período experimental $(P<0,05)$, diferindo na amplitude e refletindo as mudanças que ocorrem no mês final de gestação. 


\subsection{IGF-I e IgG no colostro e nas secreções lácteas}

Vários autores têm verificado altas concentrações de IGF-I no colostro de bovinos, com níveis médios variando de 100 a $500 \mathrm{ng} / \mathrm{mL}$, sendo inferior a 40 $\mathrm{ng} / \mathrm{mL}$ no leite (Simmen et al., 1988; Zhao et al., 1991; Vacher et al., 1993; Donovan et al., 1994; Hardon et al., 1997; Blum \& Hammon, 2000). No presente estudo, o objetivo da administração de rbST para os animais durante o período seco era aumentar a concentração sérica de IGF-I e, conseqüentemente, as concentrações no colostro e subseqüentes secreções lácteas.

As concentrações médias de IGF-I $(\mathrm{ng} / \mathrm{mL})$ referentes ao colostro e subseqüentes secreções lácteas dos animais distribuídos nos dois grupos são apresentadas na Tabela 10 e Figura 8. O efeito significativo de tratamento $(P<0,05)$ encontrado em função da média geral dos dois grupos, está relacionado a diferenças encontradas na concentração de IGF-I no colostro. O tratamento com rbST aumentou $(P<0,05)$ a concentração de IGF-I no colostro em $30 \%$ quando comparado aos animais controle (874,53 $\pm 335,02$ e 674,15 \pm $269,53 \mathrm{ng} / \mathrm{mL}$, respectivamente). As concentrações de IGF-I no colostro das vacas tratadas com rbST foram 1,5 a 2 vezes maiores que as observadas em experimentos prévios (Malven et al., 1987; Vega et al., 1991). 
Tabela 10. Concentrações médias de IGF-I (ng/mL) referentes ao colostro e subseqüentes secreções lácteas

\begin{tabular}{|c|c|c|c|c|c|c|c|c|c|c|c|c|c|}
\hline \multirow[b]{2}{*}{ Trat $^{1}$} & \multicolumn{9}{|c|}{ Secreções Lácteas } & \multicolumn{4}{|c|}{$\mathbf{P}^{2}$} \\
\hline & $\begin{array}{c}\text { Colostr } \\
0\end{array}$ & $\begin{array}{c}2^{-\mathrm{a}} \\
(12 \mathrm{~h})\end{array}$ & $\begin{array}{c}4^{\underline{a}} \\
\text { (1 dia) }\end{array}$ & $\begin{array}{c}6^{\underline{a}} \\
\text { (2 dias) }\end{array}$ & $\begin{array}{c}8^{\underline{a}} \\
\text { (3 dias) }\end{array}$ & $\begin{array}{c}10^{\mathrm{a}} \\
\text { (4 dias) }\end{array}$ & $\begin{array}{c}12^{\underline{a}} \\
\text { (5 dias) }\end{array}$ & $\begin{array}{c}14^{\underline{a}} \\
\text { (6 dias) }\end{array}$ & $\begin{array}{c}16^{\underline{a}} \\
\text { (7 dias) }\end{array}$ & $\begin{array}{l}\text { Média } \\
\text { Geral }\end{array}$ & Trat & Período & $\begin{array}{c}\text { Trat X } \\
\text { Período }\end{array}$ \\
\hline \multirow[t]{2}{*}{ Controle } & $674,15^{\mathrm{a}}$ & 575,63 & 319,69 & 117,34 & 46,75 & 19,75 & 18,55 & 16,35 & 14,02 & 200,25 & & & \\
\hline & & & & & & & & & & & 0,04 & 0,01 & 0,52 \\
\hline ST & $874,53^{b}$ & 681,79 & 307,07 & 77,23 & 32,80 & 13,40 & 14,44 & 13,01 & 11,70 & 225,11 & & & \\
\hline Média & $774,34^{\mathrm{A}}$ & $628,71^{\mathrm{B}}$ & $313,38^{C}$ & $97,28^{\mathrm{D}}$ & $39,77^{\mathrm{D}}$ & $16,57^{\mathrm{D}}$ & $16,49^{\mathrm{D}}$ & $14,68^{\mathrm{D}}$ & $12,86^{\mathrm{D}}$ & & & & \\
\hline $\mathrm{DP}^{3}$ & 302,41 & 332,90 & 209,87 & 82,20 & 32,89 & 7,68 & 8,04 & 4,19 & 5,46 & & & & \\
\hline
\end{tabular}

${ }^{a b}$ Médias seguidas de letras diferentes na mesma coluna diferem entre si pelo teste $F(P<0,05)$

${ }^{A B C D}$ Médias seguidas de letras diferentes na mesma linha diferem entre si pelo teste de Tukey $(P<0,05)$.

${ }^{1}$ Trat: Controle - tratamento com vitamina E, ST - tratamento com rbST (somatotropina bovina recombinante); ${ }^{2} \mathrm{P}=$ probabilidade; ${ }^{3} \mathrm{DP}=\mathrm{desvio}$ padrão. 


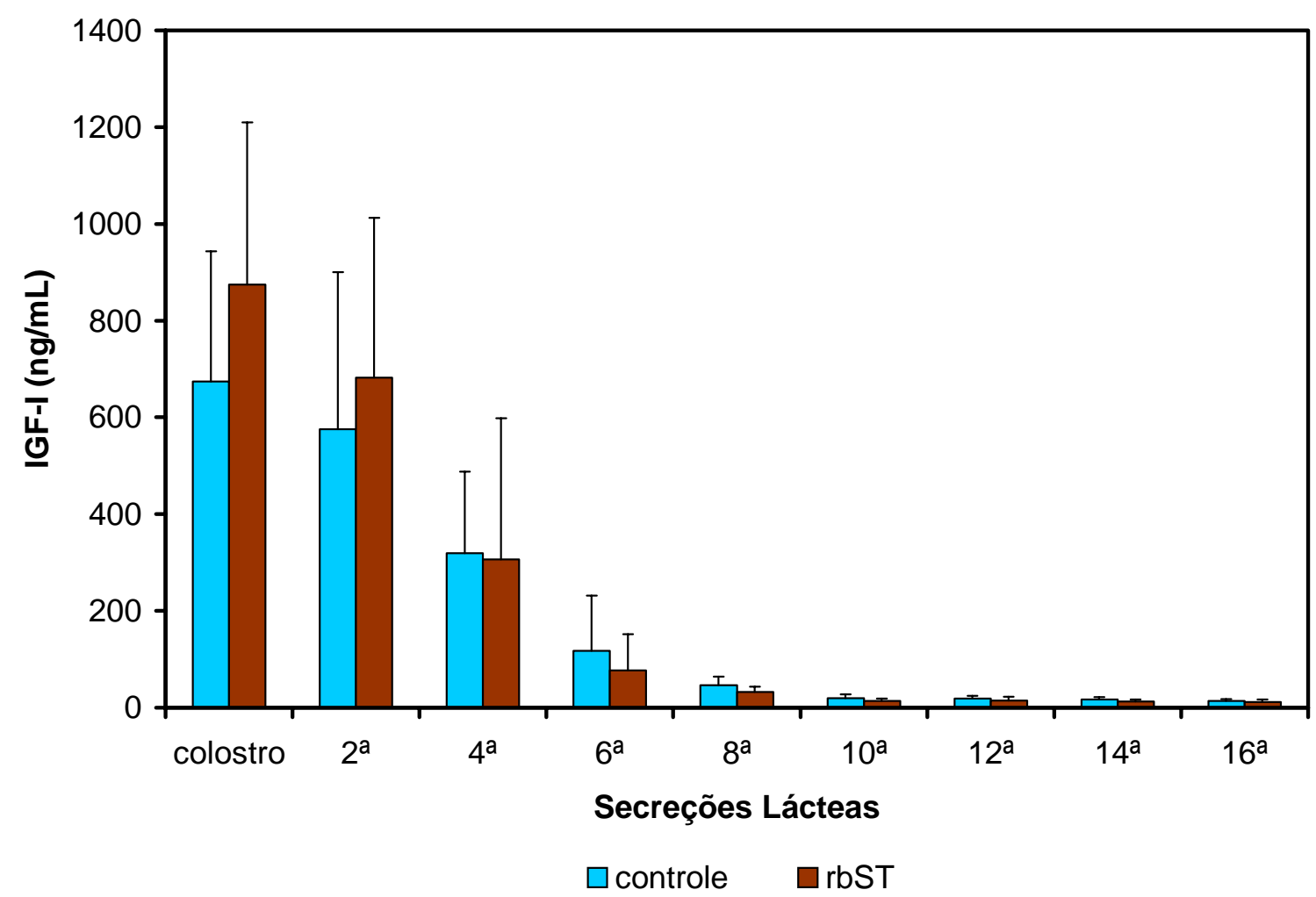

Figura 8 - Concentrações de IGF-I (média \pm desvio padrão) no colostro e subseqüentes secreções lácteas

No entanto, Hadsell et al. (1993), utilizando somatotropina em vacas leiteiras com início oito semanas antes da data prevista de parição, obtiveram concentração média de IGF-I no colostro de $1116,15 \mathrm{ng} / \mathrm{mL}$. Mas, apesar dessa concentração média ser superior a encontrada neste estudo $(874,53 \mathrm{ng} / \mathrm{mL})$, é importante ressaltar que foi verificado uma elevada variação entre animais, com valor máximo observado de 1413,07 ng/mL.

O comportamento de IGF-I sérico acompanha de forma estreita a flutuação de IgG no período pré-parto, com ambas variáveis apresentando queda significativa entre o início do período experimental e o parto, sugerindo a remoção ativa das mesmas da corrente sangüínea para a glândula mamária. No entanto, Hadsell et al. (1993), utilizando um índice idealizado por Brandon et al. 
(1971), o qual calcula como produto a taxa de secreção de IgG:IGF-I sérica em relação a IGF-l:IgG nas secreções lácteas pré-parto e no colostro, com o objetivo de determinar mudanças temporais comparativas entre as duas variáveis, observaram através do mesmo que a diminuição na concentração sérica de IgG corresponde ao acúmulo dessa proteína nas secreções lácteas, o que pode não ser totalmente verdadeiro para IGF-I.

Esta observação, bem como o fato das secreções lácteas pré-parto apresentarem concentração 20 vezes maior de IGF-I em relação às concentrações séricas, sugerem que a difusão de IGF-I do sangue para as secreções lácteas pode não explicar totalmente a variação nas mesmas (Malven et al., 1987; Vega et al., 1991; Hadsell et al., 1993).

Além do mecanismo de transferência da corrente sangüínea materna para a glândula mamária, que se constitui como única possibilidade para o acúmulo de IgG, têm-se sugerido que os IGFs presentes nas secreções lácteas podem também, se originar da síntese local da glândula, síntese de novo ou por um mecanismo de difusão acoplado às IGFBPs que prolongariam a meia-vida dos IGFs nas secreções lácteas. Além do acúmulo nas secreções lácteas, a alta concentração de IGF-I na glândula mamária durante o final do período seco sugere que o IGF-I participaria como um mediador local do crescimento e desenvolvimento das células epiteliais mamárias (Glimm et al., 1988; Simmen et al., 1988; Hadsell et al., 1990; Weber et al., 2000). Campbell et al. (1991) e Weber et al. (2000) demonstraram que explantes de tecido mamário sintetizam e secretam IGF-I e IGFBPs, exclusivamente na porção do estroma, desempenhando um papel parácrino de IGF-I no desenvolvimento do epitélio. Porém, o nível de síntese parece ser muito baixo para explicar a concentração do IGF nas secreções lácteas (Baumrucker \& Blum, 1993).

Exceto o colostro, primeira secreção láctea, as demais secreções não foram influenciadas pelo tratamento com rbST, havendo somente efeito significativo de período $(P<0,05)$, com queda pronunciada das concentrações 
nas secreções lácteas a partir do colostro. Até o sétimo dia de coleta observouse queda de $98 \%(P<0,05)$ em relação à concentração inicial, tendo-se observado no leite uma concentração média de $12,86 \mathrm{ng} / \mathrm{mL}$ de IGF-I. Flutuação semelhante de IGF-I nas secreções lácteas foi encontrada por Blum \& Hammon (2000), Hammon et al. (2000) e Sejrsen et al. (2001).

Com os dados observados, pode-se sugerir que aumentos nos níveis de IGF-I na circulação materna pré-parto podem não refletir diretamente na condição de mobilização desse peptídeo para a glândula mamária, pois o aumento de IGF-I nas secreções lácteas depende de um conjunto de fatores, dentre os principais estão níveis de hormônio de crescimento, duração do período seco, síntese local na glândula mamária, características de produção e o balanço energético do animal.

As concentrações médias de lgG $(\mathrm{mg} / \mathrm{mL})$ referentes ao colostro e demais secreções lácteas dos animais distribuídos nos dois grupos são apresentadas na Tabela 11 e Figura 9. As concentrações de IgG no colostro e subseqüentes secreções não foram influenciadas pelo tratamento das vacas. Foi verificado somente efeito significativo de período $(P<0,05)$, ocorrendo queda progressiva das concentrações de IgG nas secreções lácteas na primeira semana de lactação, comportamento semelhante ao que se observou para IGF-I. 
Tabela 11. Concentrações médias de $\mathrm{lgG}(\mathrm{mg} / \mathrm{mL})$ referentes ao colostro e subseqüentes secreções lácteas

\begin{tabular}{|c|c|c|c|c|c|c|c|c|c|c|c|}
\hline \multirow[b]{2}{*}{ Trat $^{1}$} & \multicolumn{7}{|c|}{ Secreções Lácteas } & \multicolumn{4}{|c|}{$\mathbf{P}^{2}$} \\
\hline & $\begin{array}{c}\text { Colostr } \\
\text { o }\end{array}$ & $\begin{array}{c}2^{-\mathrm{a}} \\
(12 \mathrm{~h})\end{array}$ & $\begin{array}{c}4^{\underline{\underline{a}}} \\
(1 \mathrm{dia})\end{array}$ & $\begin{array}{c}6^{\frac{\mathrm{a}}{}} \\
\text { (2 dias) }\end{array}$ & $\begin{array}{c}8^{\underline{a}} \\
\text { (3 dias) }\end{array}$ & $\begin{array}{c}12^{\underline{a}} \\
\text { (5 dias) }\end{array}$ & $\begin{array}{c}16^{\underline{a}} \\
\text { (7 dias) }\end{array}$ & $\begin{array}{l}\text { Média } \\
\text { Geral }\end{array}$ & Trat & Periodo & $\begin{array}{c}\text { Trat X } \\
\text { Periodo }\end{array}$ \\
\hline \multirow[t]{2}{*}{ Controle } & 119,60 & 91,22 & 55,10 & 28,93 & 22,44 & 12,00 & 8,92 & 48,33 & & & \\
\hline & & & & & & & & & 0,48 & 0,01 & 0,99 \\
\hline ST & 115,27 & 82,83 & 50,32 & 29,34 & 17,10 & 10,58 & 9,08 & 44,93 & & & \\
\hline Média & $117,48^{A}$ & $87,03^{\mathrm{B}}$ & $52,71^{\mathrm{C}}$ & $29,14^{\mathrm{D}}$ & $19,77^{\mathrm{DE}}$ & $11,29^{\mathrm{DE}}$ & $9,00^{\mathrm{E}}$ & & & & \\
\hline $\mathrm{DP}^{3}$ & 33,45 & 38,22 & 29,65 & 16,01 & 10,76 & 3,44 & 1,32 & & & & \\
\hline
\end{tabular}

${ }^{A B C D E}$ Médias seguidas de letras diferentes na mesma linha diferem entre si pelo teste de Tukey $(P<0,05)$

${ }^{1}$ Trat: Controle - tratamento com vitamina E, ST - tratamento com rbST (somatotropina bovina recombinante); ${ }^{2} \mathrm{P}=$ probabilidade; ${ }^{3} \mathrm{DP}=\mathrm{desvio}$ padrão. 


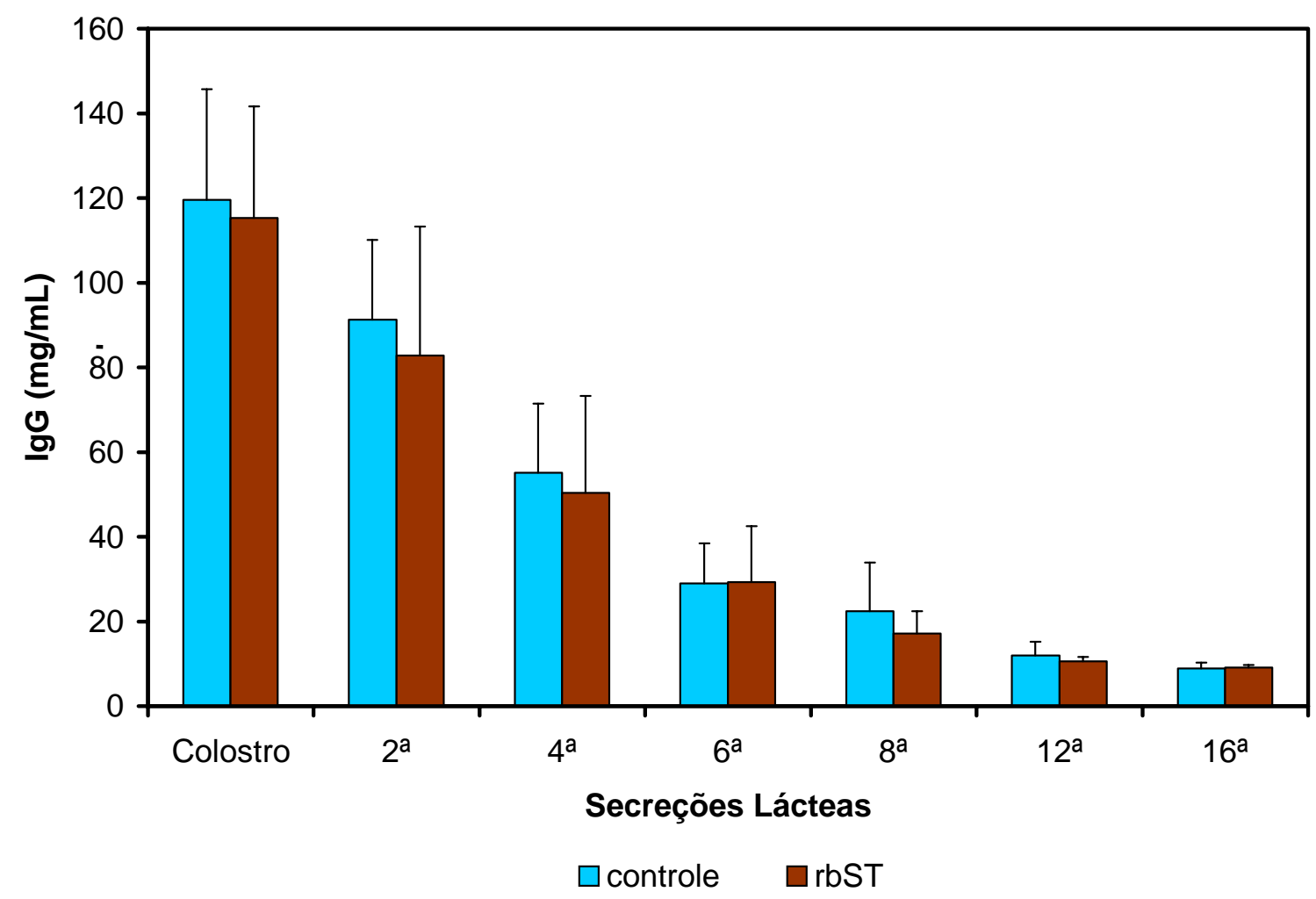

Figura 9 - Concentrações de lgG (média \pm desvio padrão) no colostro e subseqüentes secreções lácteas

Este comportamento está de acordo com os resultados obtidos por Hadsell et al. (1993), que apesar de encontrarem efeito significativo do tratamento com rbST sobre os níveis séricos de $\operatorname{lgG}_{1}$ no período pré-parto, também não observaram mudanças quanto às concentrações de IgG no colostro e demais secreções. Já Macewko et al. (2002), trabalharam com animais de corte que receberam somatotropina pré-parto e não verificaram diferenças na concentração de $\operatorname{lgG}_{1}$ e IgM no colostro, observando somente um aumentou de $35 \%(P<0,05)$ na concentração de $\operatorname{lgG}_{2}$ nas secreções lácteas. Entretanto, como $\operatorname{lgG}_{2}$ representa apenas uma pequena fração das imunoglobulinas totais presentes no colostro, um aumento de seus níveis nas secreções lácteas pode não ter significado relevante para o animal recém-nascido. 
As concentrações médias de IgG observadas no colostro foram 119,60 \pm 26,14 e $115,27 \pm 26,38 \mathrm{mg} / \mathrm{mL}$ para os grupos controle e rbST, respectivamente. Fleenor \& Stott (1980) classificam colostros com teores abaixo de 21,8 mg de imunoglobulinas $/ \mathrm{mL}$, como de baixo valor imunológico e acima de $49,82 \mathrm{mg} / \mathrm{mL}$ como de adequado valor imunológico. Os valores observados no presente trabalho se encontram dentre os mais elevados citados na literatura para vacas da raça Holandesa, que variam entre 50 e $90 \mathrm{mg} / \mathrm{mL}$ (Burton et al., 1989; Pritchett et al., 1991; Tyler et al., 1999; Blum \& Hammon, 2000; Morin et al., 2001).

A concentração de imunoglobulinas no colostro é máxima no momento do parto e decresce a cada ordenha sucessiva no período pós-parto. Apesar da diminuição, a IgG continua sendo a principal imunoglobulina durante a lactação. Segundo Kruse (1970), o conteúdo de IgG no colostro declina rapidamente, sendo que 16 horas após o parto a redução chega a 40\%. No presente trabalho, observou-se uma redução de 26 e 55\%, 12 e 24 horas após o parto, respectivamente, sendo que as médias de concentração encontradas mantiveram-se elevadas, 87,03 e $52,71 \mathrm{mg} / \mathrm{mL}$. Até o sétimo dia de coleta observou-se queda de $92 \%$ da concentração inicial, tendo-se encontrado no leite uma concentração média de $9,00 \mathrm{mg} / \mathrm{mL}$ de $\mathrm{lgG}$.

Os dados relativos ao uso da somatotropina bovina e sistema imune não são conclusivos. Os fatores como a dose de rbST, balanço energético, condição imunológica do animal e principalmente estado fisiológico, não foram totalmente explorados. O estabelecimento conclusivo da ação da rbST sobre o aumento de anticorpos séricos e possível alteração das secreções lácteas trariam importantes possibilidades de uso com benefícios ao desenvolvimento e higidez do animal recém-nascido. 


\subsection{IGF-I, IgG e PT séricos dos bezerros}

As médias originais (média \pm desvio padrão) das variáveis séricas que sofreram transformação, IGF-I e IgG, são apresentadas no Apêndice 2.

Testou-se como covariável o peso ao nascimento para todas as variáveis séricas estudadas, não sendo a mesma significativa para nenhuma delas $(P>0,05)$ e assim não foi considerada no modelo.

As médias das concentrações de IGF-I são apresentadas na Tabela 12. As médias de IGF-I sérico não diferiram entre os tratamentos $(P>0,05)$, verificandose somente efeito significativo de período $(P<0,05)$. 
Tabela 12. Concentrações séricas de IGF-I $(\mathrm{ng} / \mathrm{mL})$ dos bezerros do nascimento até sete dias de vida

\begin{tabular}{|c|c|c|c|c|c|c|c|c|c|c|c|c|c|}
\hline \multirow[b]{2}{*}{ Trat $^{1}$} & \multicolumn{9}{|c|}{ Idade } & \multicolumn{4}{|c|}{$\mathbf{P}^{2}$} \\
\hline & $\mathbf{O h}$ & $12 \mathrm{~h}$ & 1 dia & 2 dias & 3 dias & 4 dias & 5 dias & 6 dias & 7 dias & $\begin{array}{l}\text { Média } \\
\text { Geral }\end{array}$ & Trat & Período & $\begin{array}{c}\text { Trat X } \\
\text { Período }\end{array}$ \\
\hline Controle & 15,83 & 25,17 & 19,06 & 10,63 & 16,12 & 10,98 & 15,54 & 23,01 & 26,64 & 17,26 & & & \\
\hline ST & 25,90 & 31,28 & 19,47 & 13,92 & 19,63 & 16,54 & 17,48 & 21,30 & 14,21 & 19,33 & & & \\
\hline Média & $20,24^{B}$ & $28,06^{A}$ & $19,27^{\mathrm{BC}}$ & $12,16^{\mathrm{C}}$ & $17,79^{B C}$ & $13,48^{\mathrm{BC}}$ & $16,48^{\mathrm{BC}}$ & $22,14^{\mathrm{B}}$ & $19,46^{\mathrm{BC}}$ & & & & \\
\hline
\end{tabular}

${ }^{\mathrm{ABC}}$ Médias seguidas de letras diferentes na mesma linha diferem entre si pelo teste de Tukey $(P<0,05)$.

${ }^{1}$ Trat: Controle - bezerros referentes às vacas do tratamento com vitamina E, ST - bezerros referentes às vacas do tratamento com rbST (somatotropina bovina recombinante) ${ }^{2} \mathrm{P}=$ probabilidade. 
No presente estudo, foi observado uma grande variação da concentração de IGF-I ao nascimento, os bezerros apresentaram valores extremos variando de 10 a $100 \mathrm{ng} / \mathrm{mL}$. Esse fato pode ser a causa de não se ter detectado diferenças entre os tratamentos nesta data, mesmo com os animais nascidos das vacas do grupo rbST apresentarem concentração média de IGF-I de 25,90 $\mathrm{ng} / \mathrm{mL}$ em comparação aos animais nascidos das vacas controle com concentração média de 15,83 ng/mL. Gallo \& Block (1990), trabalhando com vacas tratadas com rbST e os respectivos bezerros, também não observaram diferenças significativas nas concentrações séricas de IGF-I dos bezerros nascidos de vacas tratadas em comparação a bezerros nascidos de vacas não tratadas.

Vários trabalhos relatam decréscimo nos níveis circulantes de IGF-I na primeira semana de vida, independentemente da ingestão de colostro ou substitutos lácteos (Breier et al., 1988; Vacher et al., 1995; Hammon \& Blum, 1997; Hardon et al., 1997; Kühne et al., 2000; Nussbaum et al., 2002). No presente trabalho, foi observado um aumento significativo de $39 \%$ dos níveis médios circulantes de IGF-I do nascimento até doze horas de vida de 20,24 para $28,06 \mathrm{ng} / \mathrm{mL}(\mathrm{P}<0,05)$, não sendo mais observadas diferenças significativas a partir do segundo dia de idade. Já Sparks et al. (2003), não observaram aumento na concentração sérica de IGF-I do nascimento aos dois dias de idade, no entanto utilizando colostro com concentração média de IGF-I de 75,51 ng/mL (4L/animal/dia).

Apesar da diferença encontrada quanto a concentração de IGF-I no colostro das vacas tratadas com rbST em relação ao grupo controle, observouse grande variação quanto a concentração de IGF-I nos colostros desses grupos. No grupo que recebeu somatotropina foi verificado valores extremos variando de 500 a $1400 \mathrm{ng} / \mathrm{mL}$. Assim, uma possível alteração dos níveis circulantes de IGF-I dos bezerros, em função do colostro ingerido, poderia não ser detectada pela divisão dos grupos ter sido somente em função do 
tratamento da mãe no período pré-parto.

Por essa razão, os bezerros foram reagrupados tomando-se como critério a quantidade de IGF-I ingerida em função do peso vivo ao nascimento e a concentração de IGF-I no colostro, independente do tratamento da mãe no período pré-parto. Avaliou-se assim, a influência direta da concentração de IGF-I no colostro e os níveis séricos encontrados nos animais na primeira semana de vida. Os animais foram então redistribuídos em dois grupos, sendo o grupo 1 com ingestão de IGF-I de 500 a $3000 \mu$ e o grupo 2 com ingestão de IGF-I de 3000 a $6000 \mu g$.

Para este reagrupamento a concentração sérica inicial de IGF-I ao nascimento foi utilizada como covariável $(P<0,05)$, para avaliarmos o efeito da concentração de IGF-I ingerida pelo animal, independente da concentração endógena ao nascimento. Testou-se também, como covariável, peso ao nascimento, a qual não se mostrou significativa $(P>0,05)$ e, portanto não foi considerada no modelo.

Os níveis médios corrigidos de IGF-I (ng/mL) dos bezerros distribuídos nos dois grupos até o sétimo dia de vida são apresentados na Tabela 13 e as concentrações médias originais (média \pm desvio padrão) dos bezerros são apresentadas no Apêndice 3.

Mesmo utilizando-se valores extremos quanto à quantidade de IGF-I ingerida pelos bezerros, não houve diferenças entre os grupos $(P>0,05)$, encontrando-se somente efeito significativo de período $(P<0,05)$. Apesar da concentração sérica de IGF-I apresentada pelo grupo 2 às 12 e 24 horas de vida ser 1,5 vezes maior em relação ao grupo 1, não foi detectada diferença significativa entre os mesmos ( $P=0,1502$ e $P=0,1414$, respectivamente), este fato, como já mencionado anteriormente, pode estar relacionado a grande variação encontrada entre os animais. 
Tabela 13. Concentrações séricas de IGF-I (ng/mL) dos bezerros do nascimento até sete dias de vida redistribuídos em dois grupos em função da massa de IGF-I ( $\mu \mathrm{g}$ ) ingerida do colostro (médias corrigidas pela covariável IGF-I sérico ao nascimento)

\begin{tabular}{|c|c|c|c|c|c|c|c|c|c|c|c|c|c|}
\hline \multirow[b]{2}{*}{ Grupo $^{1}$} & \multicolumn{9}{|c|}{ Idade } & \multicolumn{4}{|c|}{$\mathbf{P}^{2}$} \\
\hline & $\mathbf{O h}$ & $12 \mathrm{~h}$ & $1 \mathrm{dia}$ & 2 dias & 3 dias & 4 dias & 5 dias & 6 dias & 7 dias & $\begin{array}{c}\text { Média } \\
\text { Geral }\end{array}$ & Trat & Período & $\begin{array}{r}\text { Trat X } \\
\text { Período }\end{array}$ \\
\hline 1 & 47,79 & 27,78 & 19,14 & 14,37 & 19,39 & 13,78 & 17,73 & 24,97 & 27,19 & 19,90 & & & \\
\hline 2 & 31,57 & 43,89 & 29,69 & 14,34 & 24,93 & 21,18 & 23,65 & 29,19 & 17,43 & 24,23 & 0,41 & 0,01 & 0,33 \\
\hline Média & - & $34,92^{\mathrm{A}}$ & $23,84^{\mathrm{B}}$ & $14,36^{C}$ & $21,99^{\mathrm{BC}}$ & $17,09^{\mathrm{BC}}$ & $20,48^{\mathrm{BC}}$ & $27,00^{\mathrm{AB}}$ & $21,78^{\mathrm{BC}}$ & & & & \\
\hline
\end{tabular}

${ }^{\mathrm{ABC}}$ Médias seguidas de letras diferentes na mesma linha diferem entre si pelo teste de Tukey $(P<0,05)$

${ }^{1}$ Grupo 1: ingestão de 500 a $3000 \mu \mathrm{g}$ de IGF-I, Grupo 2: ingestão de 3000 a $6000 \mu \mathrm{g}$ de IGF-I; ${ }^{2} \mathrm{P}=$ probabilidade. 
A flutuação sérica de IGF-I dos bezerros reagrupados mostrou comportamento semelhante à divisão original dos grupos controle e rbST, como pode ser observado na Figura 10.

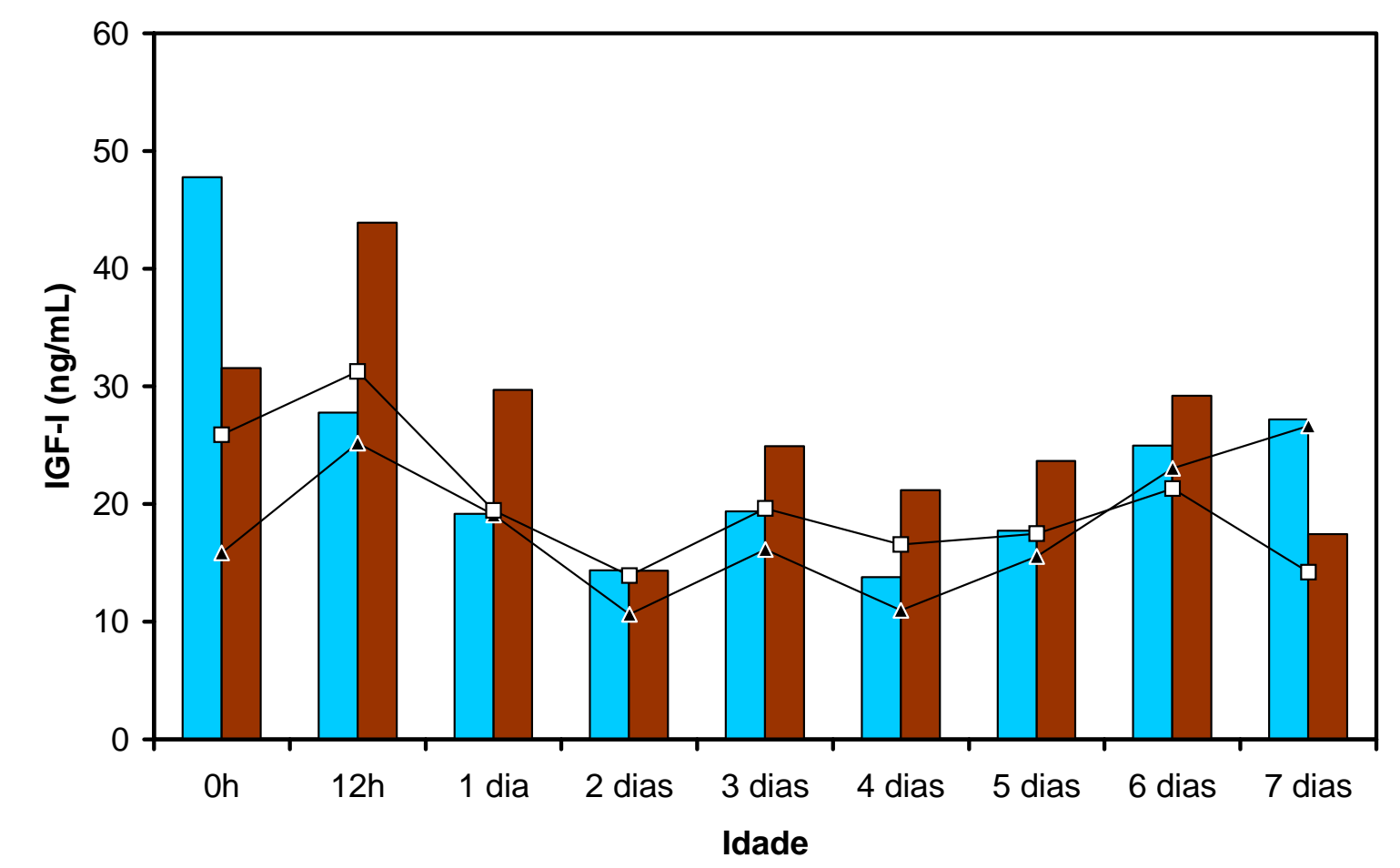

grupo $1 \square$ grupo 2 -- controle - - -rbST

Grupo 1: ingestão de 500 a $3000 \mu \mathrm{g}$ de IGF-I, Grupo 2: ingestão de 3000 a $6000 \mu \mathrm{g}$ de IGF-I. Controle - bezerros referentes às vacas do tratamento com vitamina $\mathrm{E}, \mathrm{rbST}$ - bezerros referentes às vacas do tratamento com rbST (somatotropina bovina recombinante).

Figura 10 - Flutuação sérica de IGF-I (ng/mL) dos bezerros distribuídos em função do tratamento das mães e da massa de IGF-I $(\mu \mathrm{g})$ consumida do colostro 
Assim como ocorreu para a divisão original dos grupos, no reagrupamento também foi observado que a concentração de IGF-I às 12 horas de vida se mostrou superior $(P<0,05)$ em relação a todos os outros períodos. No entanto, pela análise de regressão entre a quantidade de IGF-I ingerida do colostro e os níveis de IGF-I circulantes nos animais às 12 e 24 horas (Figura 11), pode-se sugerir que a massa de IGF-I consumida não está diretamente relacionada com as mudanças nos níveis séricos observados nessas datas $\left(R^{2}=0,1269\right.$ e $R^{2}=$ 0,0183, para 12 e 24 horas, respectivamente, $P>0,05)$, sugerindo que o mesmo não seja absorvido pelas células intestinais, sendo seu efeito principal o de mediador do desenvolvimento local (Baumrucker et al., 1994; Hammon \& Blum, 1997; Hammon et al., 2002). Aliada a essa informação, Sparks et al. (2003) observaram que a diferença entre os níveis séricos de IGF-I ao nascimento às 48 horas de vida, não estava correlacionada com as concentrações de IGF-I no colostro. Os autores verificaram que animais nascidos com concentrações elevadas de IGF-I (entre 10 e $40 \mathrm{ng} / \mathrm{mL}$ ) apresentaram decréscimo significativo entre o nascimento e 48 horas de vida, sendo que os bezerros nascidos com baixas concentrações (<10 ng/mL) não apresentaram diferenças no mesmo intervalo. Essas observações sugerem que a concentração de IGF-I ao nascimento pode se constituir em um importante determinante na concentração de IGF-I às 48 horas de vida. 

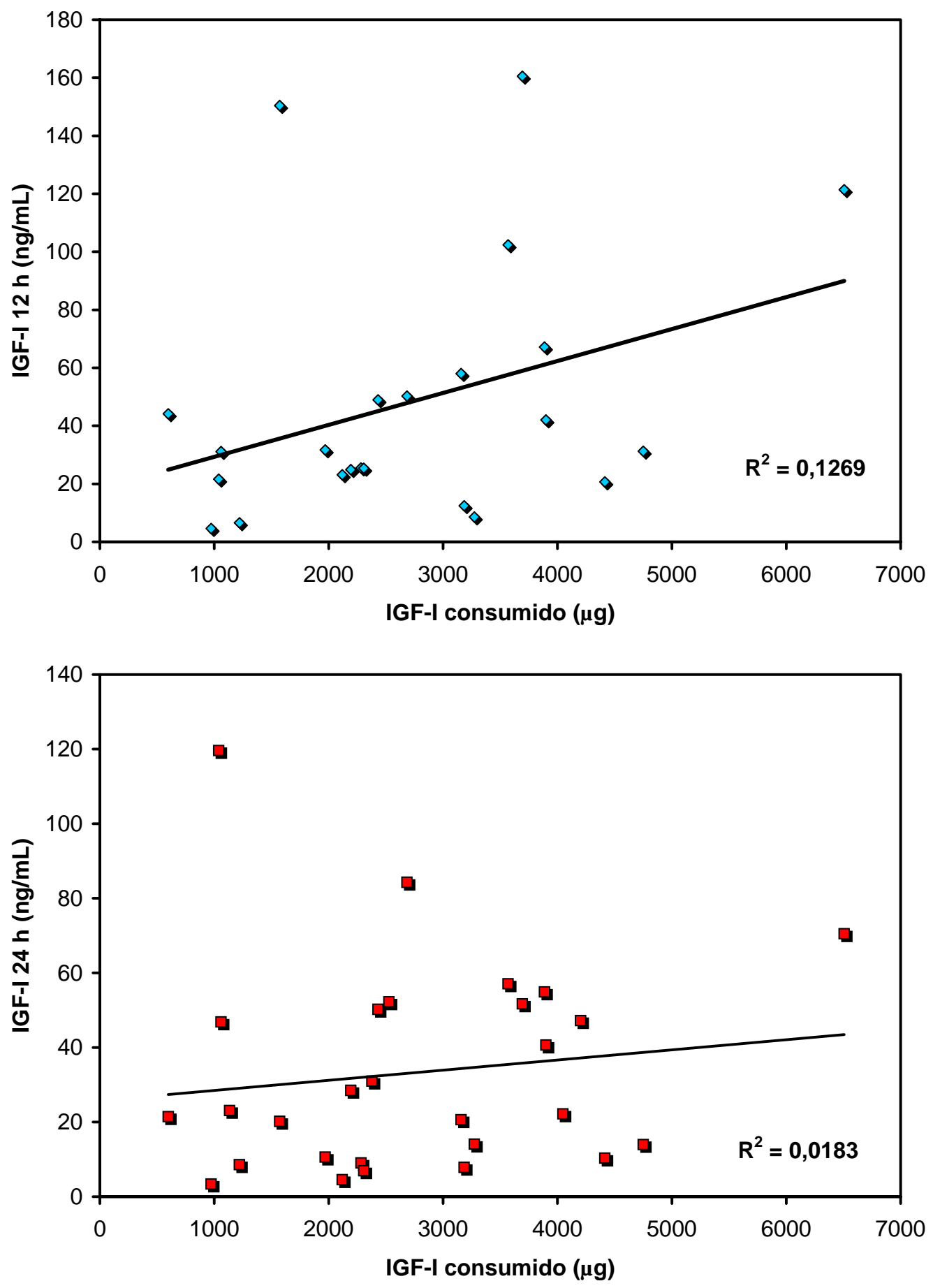

Figura 11 - Regressão entre a concentração sérica de IGF-I (ng/mL) às 12 e 24 horas de vida e a massa de IGF-I $(\mu \mathrm{g})$ consumida do colostro 
Esse comportamento também foi verificado por outros autores. Vacher et al. (1995), fornecendo quantidades suprafisiológicas de ${ }^{125}$ I-IGF-I administrados diretamente em alças do jejuno de bezerros de um dia de idade, observaram pequenas quantidades de ${ }^{125}$ I-IGF-I na veia mesentérica drenada do segmento. Burrin et al. (1996), suplementando suínos com $3500 \mu \mathrm{g}$ de IGF-l/kg/dia durante os quatro primeiros dias de vida, também não observaram alteração nos níveis de IGF-I circulantes do animal. Philipps et al. (1995), trabalhando com ratos e Odle et al. (1996) com suínos, também não verificaram a absorção de ${ }^{125}$ I-IGF-I quando o mesmo foi administrado oralmente aos animais. Donovan et al. (1997) administraram ${ }^{125}$ I-rhIGF-I oralmente para suínos recém-nascidos e observaram que o ${ }^{125}$ I-rhIGF-I absorvido representava somente $0,25 \%$ do total do "pool" plasmático. Cordano et al. (2000) observaram elevada correlação $(r=0,92)$ da concentração de RNAm hepático de IGF-I com as concentrações de IGF-I plasmáticas em bezerros na primeira semana de vida, sugerindo que a produção hepática de IGF-I determina os níveis plasmáticos.

Alguns estudos sugerem que, além da quantidade de colostro ingerida pelo animal recém-nascido, a freqüência de ingestão pode alterar os níveis séricos de IGF-I. Egli \& Blum (1998), trabalhando com bezerros recém-nascidos que permaneciam com as mães tendo, conseqüentemente, livre acesso ao colostro e leite, observaram aumento da concentração sérica de IGF-I na primeira semana de vida. Nussbaum et al. (2002) avaliaram a freqüência de ingestão da dieta líquida na primeira semana de vida e observaram que bezerros com maior freqüência de ingestão diária apresentaram maiores concentrações de IGF-I aos sete dias de vida em comparação aos animais que recebiam duas refeições diárias. No entanto, os autores relacionam as maiores concentrações de IGF-I com uma maior ingestão de nutrientes, em função desses animais mostrarem uma tendência a apresentar concentrações mais elevadas de glucose, triglicerídeos e insulina aos sete dias de vida. Já Hammon et al. (2002), trabalhando com bezerros consumindo colostro ad libitum nos três primeiros dias de vida, não observaram aumento das concentrações de IGF-I plasmático 
até sete dias de idade.

Independente do tratamento e do reagrupamento, as concentrações séricas de IGF-I nos bezerros recém-nascidos foram substancialmente menores em relação a um animal adulto bem nutrido (ao redor de $120 \mathrm{ng} / \mathrm{mL}$, Breier et al., 1988; Ronge \& Blum, 1988; Cordano et al., 2000), demonstrando que as mudanças nos níveis circulantes de IGF-I nos bezerros são dependentes, principalmente, da idade e da nutrição.

As médias das concentrações de $\lg G(\mathrm{mg} / \mathrm{mL})$ dos bezerros do nascimento até sete dias de idade são apresentadas na Tabela 14.

As médias de IgG sérica apresentaram uma tendência a diferir significativamente entre os tratamentos $(P=0,0702)$. Verificou-se efeito significativo de período $(P<0,05)$, não havendo interação significativa entre tratamento e período. A diferença entre os tratamentos só foi observada ao nascimento e às 12 horas de vida e pode estar relacionada com o período em que a variável atinge o pico de concentração sérica, e não a diferenças relacionadas ao tratamento, pois também não foram encontradas diferenças significativas na concentração de lgG no colostro fornecido para ambos os grupos. As imunoglobulinas são absorvidas intactas passando do lume intestinal para a circulação sangüínea nas primeiras horas de vida, mecanismo que ocorre na primeira geração de células intestinais (Kruse, 1983), sendo que as concentrações atingem o pico entre 24 e 48 horas de vida (Ribeiro et al., 1983; Machado Neto \& Packer, 1986, Daniele et al., 1994; Pauletti et al., 2002). 
Tabela 14. Concentrações séricas de IgG $(\mathrm{mg} / \mathrm{mL})$ dos bezerros do nascimento até sete dias de vida

\begin{tabular}{cccccccccccccccc}
\hline & \multicolumn{10}{c}{ Idade } & $\mathbf{P}^{2}$ \\
\cline { 2 - 12 } Trat $^{1}$ & $\mathbf{0 ~ h}$ & $\mathbf{1 2} \mathbf{~ h}$ & $\mathbf{1}$ dia & $\mathbf{2}$ dias & $\mathbf{3}$ dias & $\mathbf{4}$ dias & $\mathbf{5}$ dias & $\mathbf{6}$ dias & $\mathbf{7}$ dias & $\begin{array}{c}\text { Média } \\
\text { Geral }\end{array}$ & Trat & Período & $\begin{array}{c}\text { Trat X } \\
\text { Período }\end{array}$ \\
\hline Controle & $0,74^{\mathrm{a}}$ & $28,54^{\mathrm{a}}$ & 37,46 & 37,15 & 32,85 & 34,88 & 32,76 & 32,72 & 32,85 & 27,57 & 0,07 & 0,01 & 0,79 \\
ST & $0,06^{\mathrm{b}}$ & $22,98^{\mathrm{b}}$ & 33,13 & 33,98 & 33,41 & 31,38 & 30,60 & 27,71 & 28,40 & 23,97 & & \\
Média & $0,31^{\mathrm{A}}$ & $25,68^{\mathrm{B}}$ & $35,26^{\mathrm{C}}$ & $35,56^{\mathrm{C}}$ & $33,13^{\mathrm{C}}$ & $33,11^{\mathrm{C}}$ & $31,67^{\mathrm{C}}$ & $30,16^{\mathrm{C}}$ & $30,59^{\mathrm{C}}$ & \\
\hline
\end{tabular}

${ }^{\mathrm{ab}}$ Médias seguidas de letras diferentes na mesma coluna diferem entre si pelo teste $F(P<0,05)$.

${ }^{A B C}$ Médias seguidas de letras diferentes na mesma linha diferem entre si pelo teste de Tukey $(P<0,05)$

${ }^{1}$ Trat: Controle - bezerros referentes às vacas do tratamento com vitamina E, ST - bezerros referentes às vacas do tratamento com rbST (somatotropina bovina recombinante); ${ }^{2} \mathrm{P}=$ probabilidade. 
E ao contrário do que ocorreu com a variável sérica IGF-I, pela análise de regressão entre a quantidade de IgG ingerida do colostro e os níveis de IgG circulantes nos animais às 12 e 24 horas (Figura 12), observou-se que a massa de IgG consumida está diretamente relacionada às mudanças nos níveis séricos $\left(R^{2}=0,4061\right.$ e $R^{2}=0,6462$, para 12 e 24 horas, respectivamente, $\left.P<0,05\right)$. 

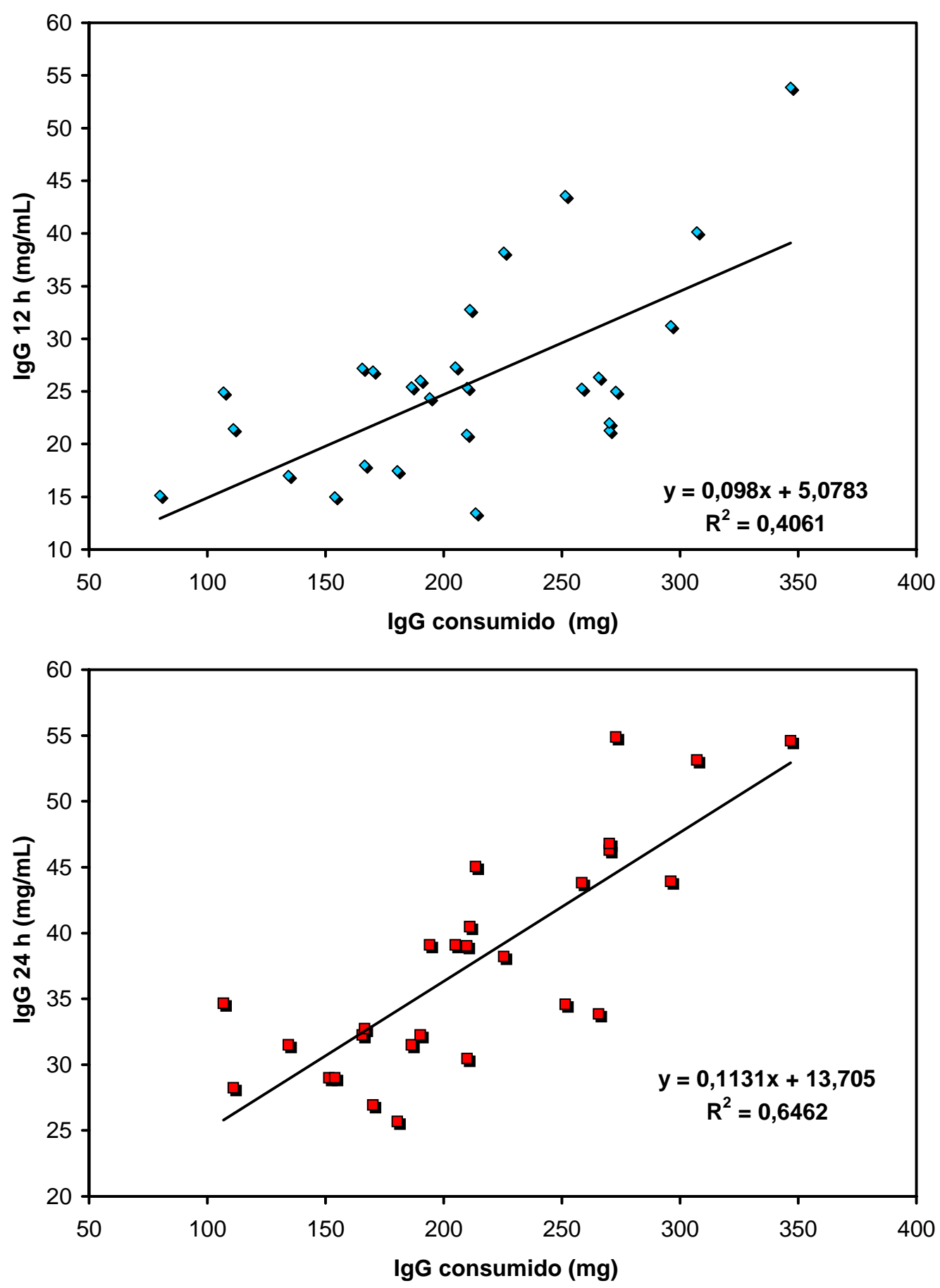

Figura 12 - Regressão entre a concentração sérica de $\operatorname{lgG}(\mathrm{mg} / \mathrm{mL})$ às 12 e 24 horas de vida e a massa de lgG (mg) consumida do colostro 
A predição da habilidade de um bezerro recém-nascido em absorver lgG, ainda hoje, é muito discutida e não está estabelecida. A massa de IgG recomendada para evitar a falha de transferência de imunidade passiva tem sido $100 \mathrm{~g}$ nas primeiras horas de vida (Gay, 1994). Entretanto, se a eficiência aparente de absorção para bezerros consumindo colostro varia entre 20 a 35\%, a ingestão de $100 \mathrm{~g}$ pode não ser suficiente para evitar possíveis falhas de transferência (Quigley \& Drewry, 1998). Em recente pesquisa, Quigley et al. (2002), estudando a eficiência aparente de absorção de imunoglobulinas em bezerros recém-nascidos, observaram que a recomendação mais adequada é o consumo de 150 a $180 \mathrm{~g}$ de IgG nas primeiras 24 horas de vida.

A administração controlada do colostro de excelente qualidade imunológica, com média de $119,60 \pm 26,14$ e $115,27 \pm 26,38 \mathrm{mg} / \mathrm{mL}$ para o grupo controle e rbST, respectivamente, proporcionou o fornecimento de uma grande massa de IgG, com média superior a $200 \mathrm{~g}$, nas primeiras horas de vida, não sendo observado animais com falha de transferência de imunidade passiva, que segundo Ribeiro et al. (1983), seria a condição de concentrações séricas menores que $10 \mathrm{mg}$ de $\mathrm{lgG} / \mathrm{mL}$ nas primeiras 48 horas de vida.

A partir de um dia de idade não foram encontradas diferenças entre as concentrações séricas de $\lg G(P>0,05)$. A boa condição imunológica estabelecida nos recém-nascidos nas primeiras horas de vida manteve níveis circulantes elevados de imunoglobulinas até sete dias de idade em ambos os grupos. Vários autores relatam que uma adequada transferência de imunidade passiva, aliando fatores de manejo, dentre os principais, tempo decorrido entre o nascimento e o fornecimento da primeira refeição de colostro e quantidade e qualidade do colostro fornecido, mantém altas concentrações séricas de lgG não só na primeira semana de vida, mas por um longo período de tempo, diminuindo estados de morbidez e mortalidade e retardando a produção endógena de anticorpos (Morin et al., 1997; Kühne et al., 2000; Rauprich et al., 2000; Pauletti et al., 2002). 
As médias das concentrações de PT ( $\mathrm{g} / 100 \mathrm{~mL})$ são apresentadas na Tabela 15. As médias de PT sérica não diferiram significativamente $(P>0,05)$ entre os tratamentos, verificando-se apenas efeito significativo de período $(P<0,05)$, não havendo interação significativa entre tratamento e período $(P>0,05)$.

A concentração sérica de PT aumentou $(P<0,05)$ após a ingestão do colostro atingindo uma concentração média de $7,99 \mathrm{~g} / 100 \mathrm{~mL}$ às 24 horas de vida e, como para a variável IgG, também não foram encontradas diferenças entre as concentrações séricas a partir desta data.

As concentrações de proteína sérica em bezerros, a partir do nascimento, seguem um padrão de variação semelhante ao que ocorre com as imunoglobulinas. Ao nascer o animal apresenta níveis baixos de PT sérica, os quais aumentam após a ingestão do colostro atingindo pico de concentração em média no $5^{0}$ dia de vida. A partir do pico de concentração, os níveis decrescem gradativamente, em parte função do catabolismo das imunoglobulinas adquiridas passivamente, até atingir a estabilidade (Machado Neto \& Packer, 1986; Daniele et al., 1994; Pauletti et al., 2002). Segundo Husband et al. (1972), as imunoglobulinas $\mathrm{G}$ possuem meia-vida de 20 dias, não sendo a produção endógena significativa no início da vida do animal por ser ainda menor do que a taxa de catabolismo dos anticorpos maternos. As flutuações das concentrações séricas de PT e IgG podem ser observadas na Figura 13. 
Tabela 15. Concentrações séricas de PT (g/100mL) dos bezerros do nascimento até sete dias de vida

\begin{tabular}{|c|c|c|c|c|c|c|c|c|c|c|c|c|c|}
\hline \multirow[b]{2}{*}{ Trat $^{1}$} & \multicolumn{9}{|c|}{ Idade } & \multicolumn{4}{|c|}{$\mathbf{P}^{2}$} \\
\hline & $0 \mathrm{~h}$ & $12 \mathrm{~h}$ & 1 dia & 2 dias & 3 dias & 4 dias & 5 dias & 6 dias & 7 dias & $\begin{array}{l}\text { Média } \\
\text { Geral }\end{array}$ & Trat & Período & $\begin{array}{c}\text { Trat X } \\
\text { Período }\end{array}$ \\
\hline Controle & 4,92 & 6,62 & 8,04 & 8,13 & 7,91 & 7,88 & 7,68 & 7,86 & 7,82 & 7,43 & & & \\
\hline ST & 5,11 & 6,79 & 7,95 & 7,80 & 8,21 & 7,60 & 7,60 & 7,68 & 7,64 & 7,38 & 0,96 & 0,01 & 0,95 \\
\hline Média & $5,02^{A}$ & $6,71^{\mathrm{B}}$ & $7,99^{\mathrm{C}}$ & $7,97^{\mathrm{C}}$ & $8,07^{C}$ & $7,74^{\mathrm{C}}$ & $7,64^{\mathrm{C}}$ & $7,77^{\mathrm{C}}$ & $7,73^{C}$ & & & & \\
\hline $\mathrm{DP}^{3}$ & 0,58 & 1,11 & 1,22 & 1,27 & 1,09 & 1,17 & 1,07 & 0,92 & 0,86 & & & & \\
\hline
\end{tabular}

${ }^{\mathrm{ABC}}$ Médias seguidas de letras diferentes na mesma linha diferem entre si pelo teste de Tukey $(\mathrm{P}<0,05)$

${ }^{1}$ Trat: Controle - bezerros referentes às vacas do tratamento com vitamina E, ST - bezerros referentes às vacas do tratamento com rbST (somatotropina bovina recombinante); ${ }^{2} \mathrm{P}=$ probabilidade; ${ }^{3} \mathrm{DP}=$ desvio padrão. 


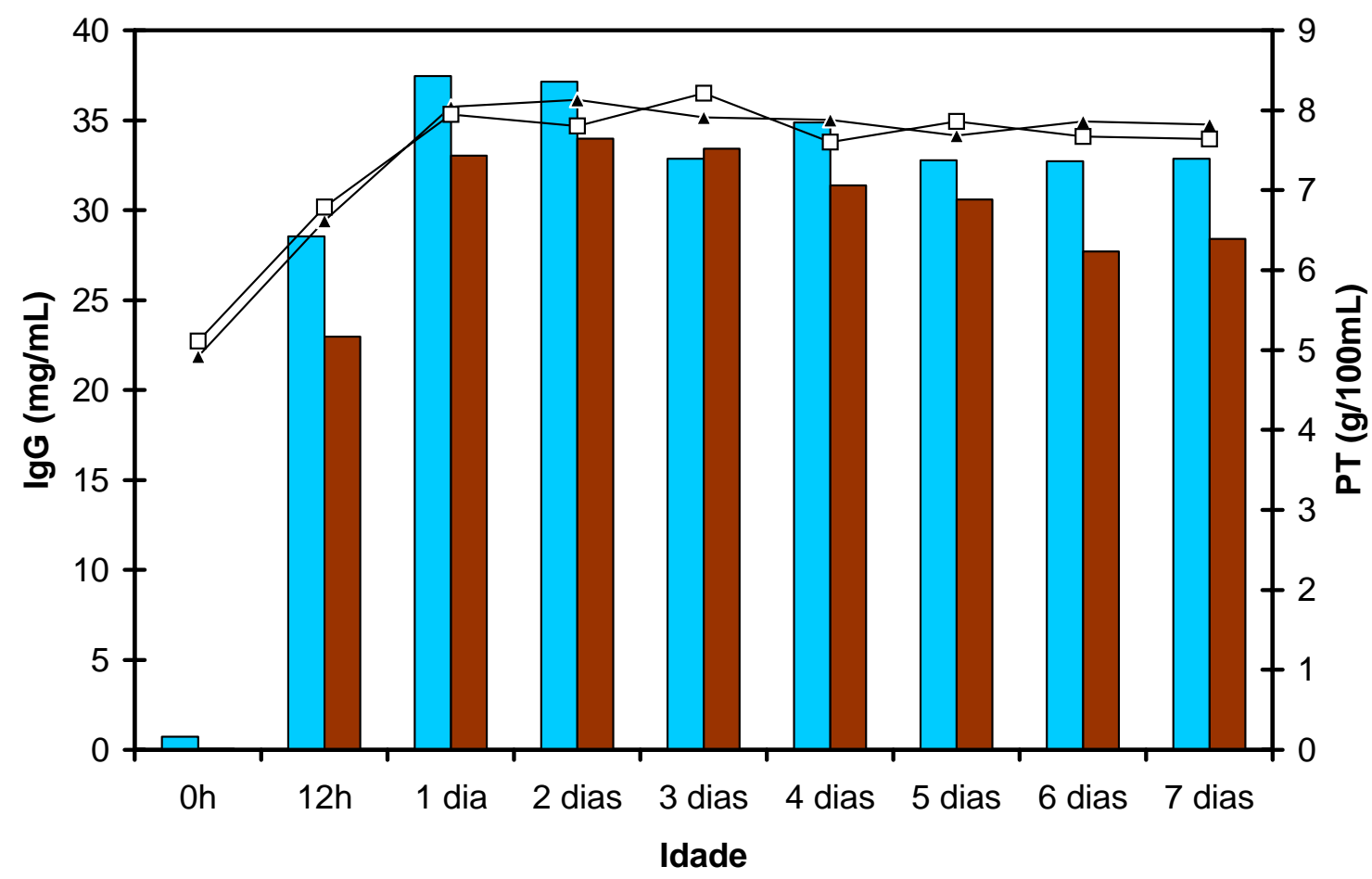

controle IgG $\square$ rbST IgG $-\Delta-$ controle PT $-\square-$ rbST PT

Controle - bezerros referentes às vacas do tratamento com vitamina $\mathrm{E}, \mathrm{rbST}$ - bezerros referentes às vacas do tratamento com rbST (somatotropina bovina recombinante).

Figura 13 - Flutuação dos níveis séricos de PT (g/100mL) e $\mathrm{lgG}(\mathrm{mg} / \mathrm{mL})$ dos bezerros do nascimento até sete dias de vida

As variáveis $\mathrm{PT}$ e $\operatorname{lgG}$ séricas foram significativamente correlacionadas $(P<0,05)$ com valor de $r=0,79$, considerando-se o período experimental total (do nascimento aos sete dias de vida), independente do tratamento. Também foi encontrada correlação significativa $(P<0,05)$ entre as variáveis às 24 horas de vida com valor de $r=0,87$, período em que as duas variáveis atingiram seus valores máximos após a ingestão do colostro. O valor da variável PT depende das imunoglobulinas adquiridas do colostro, fração protéica que no início da vida perfaz de 20 a 40\% da proteína total sérica. Vários autores citam correlações positivas entre PT e imunoglobulina sérica nos primeiros dias de vida (Nocek et 
al., 1984; Machado Neto \& Packer, 1986; Daniele et al., 1994; Baracat et al., 1997; Bessi, 1996; Pauletti et al., 2002).

No entanto, as variáveis PT e IGF-I séricas não foram significativamente correlacionadas $(r=0,16, P>0,05)$, considerando-se o período experimental total, independente do tratamento, como também não foi encontrada correlação significativa $(P>0,05)$ entre as variáveis às $12(r=0,17)$ e às $24(r=0,12)$ horas de vida. 


\subsection{Peso corporal, peso de órgãos e morfometria da mucosa intestinal}

A média de peso inicial dos animais (Tabela 16) não diferiu entre os tratamentos $(P>0,05)$, sendo $42,70 \pm 6,83$ e $45,45 \pm 7,17 \mathrm{~kg}$, para o grupo controle e o grupo rbST, respectivamente.

Vários trabalhos citados por Burton et al. (1994) em sua revisão, não detectaram diferenças no peso de bezerros ao nascimento entre animais nascidos de vacas tratadas com rbST durante o período pré-parto. Aliada a essa informação, tem sido demonstrado que o hormônio do crescimento não atravessa a placenta, estimulando somente uma limitada secreção de IGF-I pelo feto, corroborando para a hipótese que o tratamento com rbST não influenciaria o desenvolvimento bovino fetal. Em estudo recente, Vallimont et al. (2001) trabalharam com vacas que receberam somatotropina no período final de gestação e não observaram diferenças quanto ao peso vivo de bezerros nascidos de vacas tratadas com rbST em relação aos bezerros das vacas controle. Já Putnam et al. (1999), trabalhando com vacas que receberam rbST no período final de gestação, observaram que os bezerros nascidos de vacas tratadas apresentaram peso significativamente superior $(P<0,09)$ em relação aos animais controle. No entanto, os mesmos sugeriram que a diferença de peso pode estar relacionada ao aumento da concentração da glucose plasmática observada nos animais que receberam rbST e não diretamente às concentrações de IGF-I. 
Tabela 16. Peso vivo $(\mathrm{kg})$ e de órgãos ${ }^{1}(\mathrm{~g})$ dos bezerros nas três datas de abate

\begin{tabular}{|c|c|c|c|c|c|c|}
\hline & \multicolumn{2}{|c|}{ Nascimento } & \multicolumn{2}{|c|}{ Dois dias } & \multicolumn{2}{|c|}{ Sete dias } \\
\hline & Controle $^{2}$ & $\mathrm{ST}^{3}$ & Controle & ST & Controle & ST \\
\hline $\mathrm{PV}^{4}$ inicial, $\mathrm{kg}$ & 39,50 & 45,86 & 45,74 & 42,91 & 42,86 & 47,57 \\
\hline Média $\pm \mathrm{DP}^{6}$ & \multicolumn{2}{|c|}{$42,68 \pm 7,45$} & \multicolumn{2}{|c|}{$44,33 \pm 7,90$} & \multicolumn{2}{|c|}{$45,21 \pm 5,95$} \\
\hline PV final, kg & - & - & 45,17 & 43,07 & $46,86^{\mathrm{a}}$ & $50,86^{b}$ \\
\hline Média \pm DP & \multicolumn{2}{|c|}{$42,68 \pm 7,45^{A}$} & \multicolumn{2}{|c|}{$44,12 \pm 7,42^{\mathrm{A}}$} & \multicolumn{2}{|c|}{$48,86 \pm 6,43^{\mathrm{B}}$} \\
\hline coração, g & 272,14 & 272,86 & 282,86 & 292,86 & 286,43 & 280,71 \\
\hline Média \pm DP & \multicolumn{2}{|c|}{$272,50 \pm 40,44^{A}$} & \multicolumn{2}{|c|}{$287,76 \pm 51,39^{A}$} & \multicolumn{2}{|c|}{$283,57 \pm 35,11^{A}$} \\
\hline pulmão, g & 643,57 & 644,29 & 590,0 & 546,43 & 653,57 & 660,00 \\
\hline Média \pm DP & \multicolumn{2}{|c|}{$643,93 \pm 161,16^{A}$} & \multicolumn{2}{|c|}{$568,21 \pm 107,16^{\mathrm{B}}$} & \multicolumn{2}{|c|}{$656,79 \pm 59,15^{A}$} \\
\hline rins, $\mathbf{g}$ & 263,57 & 264,29 & 280,71 & 306,43 & 282,14 & 280,00 \\
\hline Média \pm DP & \multicolumn{2}{|c|}{$263,93 \pm 42,75^{A}$} & \multicolumn{2}{|c|}{$293,57 \pm 73,36^{A}$} & \multicolumn{2}{|c|}{$281,07 \pm 44,21^{\mathrm{A}}$} \\
\hline fígado, $g$ & 723,57 & 745,71 & 907,14 & 882,14 & 908,57 & 865,71 \\
\hline Média \pm DP & \multicolumn{2}{|c|}{$734,64 \pm 147,77^{A}$} & \multicolumn{2}{|c|}{$894,64 \pm 166,60^{\mathrm{B}}$} & \multicolumn{2}{|c|}{$887,14 \pm 95,47^{B}$} \\
\hline baço, $\mathbf{g}$ & 42,14 & 35,71 & 63,57 & 60,71 & 93,57 & 92,85 \\
\hline Média \pm DP & \multicolumn{2}{|c|}{$38,92 \pm 15,54^{\mathrm{A}}$} & \multicolumn{2}{|c|}{$62,14 \pm 18,99^{\mathrm{B}}$} & \multicolumn{2}{|c|}{$93,21 \pm 34,78^{\mathrm{C}}$} \\
\hline $\mathrm{TGI}^{5}, \mathbf{g}$ & 1755,71 & 2113,57 & 2495,00 & 2561,43 & 2502,86 & 2445,00 \\
\hline Média \pm DP & \multicolumn{2}{|c|}{$1934,64 \pm 437,09^{A}$} & \multicolumn{2}{|c|}{$2528,21 \pm 503,78^{\mathrm{B}}$} & \multicolumn{2}{|c|}{$2473,93 \pm 299,76^{B}$} \\
\hline
\end{tabular}


No presente estudo, através da análise de regressão, não foi encontrada correlação significativa $(P>0,05)$ entre a concentração de IGF-I ao nascimento e peso vivo (Figura 14). Sparks et al. (2003) também não observaram correlação significativa entre peso vivo e IGF-I sérico ao nascimento e às 48 horas de vida. Já Breier et al. (1988), observaram correlação significativa $(r=78, P<0,01)$ das concentrações plasmáticas de IGF-I logo após o nascimento e peso vivo.

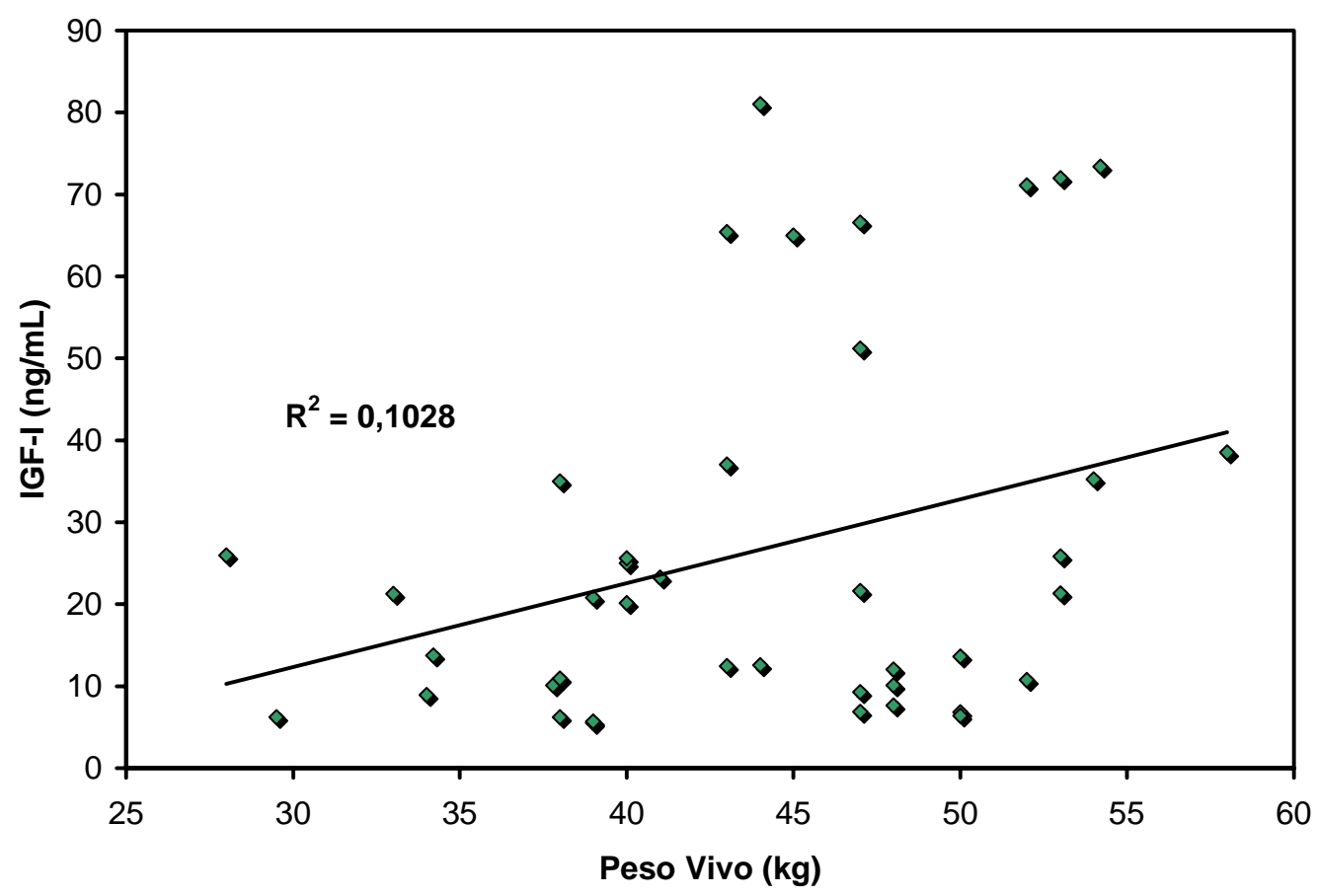

Figura 14 - Regressão entre IGF-I sérico $(\mathrm{ng} / \mathrm{mL})$ e peso vivo $(\mathrm{kg})$ dos bezerros ao nascimento 
A média de peso final dos animais do grupo abatido aos dois dias de idade (Tabela 16) não diferiu entre os tratamentos ( $P>0,05$ ), sendo $45,17 \pm 7,39$ e 43,07 $\pm 7,89 \mathrm{~kg}$, para o grupo controle e rbST, respectivamente. Já para os animais abatidos aos sete dias foi observada diferença significativa entre os tratamentos $(P<0,05)$, sendo o peso final de abate $46,86 \pm 4,14$ e $50,86 \pm 4,94$ $\mathrm{kg}$, para o grupo controle e rbST, respectivamente. Entretanto, essas diferenças encontradas podem não ser atribuídas ao efeito isolado do tratamento, visto que somente o colostro diferiu quanto às concentrações de IGF-I, não sendo encontrada diferenças significativas nas demais secreções lácteas. Egli \& Blum (1998) e Rauprich et al. (2000), trabalhando com bezerros recebendo diferentes quantidades de colostro na primeira semana de vida, também observaram diferenças no peso aos sete dias de idade. Já Nussbauman et al. (2002), trabalhando com bezerros com acesso livre ao colostro e secreções lácteas até o sétimo dia de vida não observaram diferenças no ganho de peso desses animais em comparação aos animais com acesso limitado. Os autores sugerem que diferenças no ganho de peso dos animais nesse período podem estar primariamente relacionadas a diferenças na ingestão de nutrientes, mas que efeitos adicionais de componentes bioativos do colostro podem alterar a eficiência de absorção do trato gastrintestinal.

Para análise do peso dos órgãos dos animais nas datas de abate foi utilizado o peso vivo ao nascimento como covariável. O peso dos órgãos dos bezerros não foi afetado pelo tratamento $(P>0,05)$, encontrando-se somente diferenças significativas quanto as datas de abate (Tabela 16). Somente o peso do coração e rins não diferiram em relação a data de abate. O peso do fígado, baço e trato gastrintestinal diferiram significativamente $(P<0,05)$ dos animais abatidos ao nascimento em relação aos animais abatidos aos dois e sete dias.

Houle et al. (1997), suplementando suínos com altas doses de IGF-I (200 $\mu \mathrm{g} / \mathrm{kg} / \mathrm{dia}$ por sete ou 14 dias de vida), também não observaram diferenças no peso final ao abate, taxa de crescimento e peso de órgãos dos animais. Burrin et 
al. (1995), trabalhando com leitões recém-nascidos consumindo colostro, leite ou uma fórmula contendo quantidades semelhantes de nutrientes nas primeiras 24 horas de vida, observaram que em geral, as taxas de síntese de proteína no intestino delgado, estômago, pâncreas e fígado foram semelhantes entre os grupos, com exceção das maiores taxas encontradas na porção do jejuno no grupo que consumiu colostro. Os autores sugerem que a ingestão e possível absorção intestinal dos fatores de crescimento presentes no colostro ou leite exercem pouca influência na síntese de proteína nos tecidos viscerais, sendo que o fator predominante afetando o processo anabólico seria a ingestão de nutrientes. Já Burrin et al. (1996), verificaram uma tendência $(P<0,10)$ em leitões recém-nascidos consumindo $458 \mathrm{nmol}$ de IGF-l/kg/dia $(3500 \mu \mathrm{g} / \mathrm{kg})$ por quatro dias, em ganhar mais peso e apresentar fígado e baço mais pesados em relação aos animais controle.

Vários estudos demonstram que o desenvolvimento pós-natal do trato gastrintestinal é influenciado pela ingestão de colostro. A esse respeito, resultados de estudos prévios sugerem que a magnitude da resposta do IGF-I depende da dose administrada e da duração da exposição (Xu et al., 1994; Burrin et al., 1996). Aliado a esse fato, grandes mudanças ocorrem no epitélio intestinal de bezerros recém-nacidos nos primeiros dias de vida. Por um período de curta duração, aproximadamente 48 horas, o intestino delgado apresenta uma primeira geração de células, as quais possuem a capacidade de absorver e transferir proteínas intactas do lume para a circulação sangüínea (Brambell, 1958), sendo que a absorção de anticorpos em bezerros ocorre principalmente nas regiões média e caudal do intestino delgado (James et al., 1979).

De acordo com Bessi et al. (2002a), essa fase do epitélio é caracterizada, principalmente na porção do jejuno, por apresentar vilosidades de tamanho variável, o que poderia representar diferentes estratos para aumentar a superfície exposta para a absorção do colostro. Assim, medidas lineares de profundidade de cripta e altura das vilosidades podem não representar uma 
medida exata nesse tipo de material em virtude das vilosidades serem atróficas, podendo encontrar-se distorcidas, bifurcadas, ou ainda não estarem na posição correta, sendo a decisão de onde a vilosidade termina e a cripta inicia arbitrária, introduzindo-se um artefato às medições.

Diferentes metodologias podem ser usadas para descrever diferenças na mucosa intestinal quantitativamente. O presente estudo utilizou a análise estereológica para descrever possíveis mudanças na mucosa absortiva do intestino delgado, utilizando-se o volume parcial ( $\mathrm{V} v$ ) da mucosa como parâmetro de comparação. Essa técnica foi idealizada pelo geólogo francês Delesse, em 1847, o qual propôs um teorema utilizado para quantificação de estruturas tridimensionais. Ele sugeriu que a proporção de área de um componente mineral de uma rocha era igual ao seu volume proporcional, princípio também aplicado na histologia. Delesse criou um sistema de linhas paralelas, de comprimento total conhecido que, aplicado sobre a superfície do corte de uma determinada estrutura, permite a medida do comprimento parcial dessas linhas que caem sobre um determinado componente que se deseja quantificar. Demonstrou ainda que o volume parcial ( $\mathrm{V} v$ ) ocupado pelo elemento na estrutura é numericamente igual à área ocupada por esse elemento na superfície do corte da mesma (Baddeley et al., 1986).

O tratamento com rbST não influenciou o volume parcial $(\mathrm{Vv})$ da superfície absortiva em nenhum segmento, dentro de cada data de abate $(P>0,05)$ (Tabela 17). Os segmentos diferiram nas datas de abate, sendo que no animal recémnascido a porção do jejuno médio mostrou maior $V_{v}(P<0,05)$ em relação às porções do duodeno, jejuno caudal e íleo, não diferindo somente da porção cranial. Aos dois dias de idade a porção referente ao jejuno médio reduziu seu Vv em relação aos animais recém-nascidos, não diferindo dos demais segmentos na referida data. Esse fato pode estar relacionado a fase transitória do epitélio ligada a primeira geração de células. Bessi et al. (2002a), avaliando a morfologia da mucosa intestinal em bezerros ao nascimento e com três dias de 
vida, observaram que grandes mudanças ocorrem em um período muito curto. Ao comparar a forma e tamanho das vilosidades ao microscópio eletrônico de varredura, os autores observaram que o duodeno, em apenas três dias, passa a apresentar vilosidades baixas, com superfície aparentemente plana e o jejuno mostra vilosidades menores e mais uniformes em relação aos animais recémnascidos. 
Tabela 17. Volume parcial ( $\mathrm{V} v$ \%) da mucosa absortiva do intestino delgado dos bezerros nas três datas de abate

\begin{tabular}{|c|c|c|c|c|c|c|}
\hline \multirow[b]{2}{*}{ Segmento } & \multicolumn{2}{|c|}{ Nascimento } & \multicolumn{2}{|c|}{ Dois dias } & \multicolumn{2}{|c|}{ Sete dias } \\
\hline & ${ }^{1}$ Controle & ${ }^{2} \mathrm{ST}$ & Controle & ST & Controle & ST \\
\hline Duodeno & 47,38 & 44,54 & 52,98 & 57,43 & 40,54 & 40,92 \\
\hline Média $\pm \mathrm{DP}^{3}$ & \multicolumn{2}{|c|}{$45,96 \pm 11,96^{\mathrm{Aa}}$} & \multicolumn{2}{|c|}{$55,20 \pm 11,36^{\mathrm{B}}$} & \multicolumn{2}{|c|}{$40,73 \pm 6,90^{\mathrm{Aa}}$} \\
\hline Jejuno cranial & 66,21 & 68,17 & 64,63 & 69,62 & 45,81 & 51,81 \\
\hline Média \pm DP & \multicolumn{2}{|c|}{$67,19 \pm 10,32^{\mathrm{Abc}}$} & \multicolumn{2}{|c|}{$67,12 \pm 13,29^{A}$} & \multicolumn{2}{|c|}{$48,81 \pm 11,85^{\mathrm{Ba}}$} \\
\hline Jejuno médio & 75,36 & 76,36 & 64,68 & 65,27 & 61,99 & 60,86 \\
\hline Média \pm DP & \multicolumn{2}{|c|}{$75,86 \pm 7,18^{\mathrm{Ab}}$} & \multicolumn{2}{|c|}{$64,97 \pm 15,9^{\mathrm{B}}$} & \multicolumn{2}{|c|}{$61,43 \pm 9,90^{\mathrm{Bb}}$} \\
\hline Jejuno caudal & 61,01 & 64,21 & 61,90 & 65,28 & 50,04 & 48,24 \\
\hline Média \pm DP & \multicolumn{2}{|c|}{$62,61 \pm 8,57^{\text {Acd }}$} & \multicolumn{2}{|c|}{$63,59 \pm 11,93^{A}$} & \multicolumn{2}{|c|}{$49,14 \pm 9,04^{\mathrm{Ba}}$} \\
\hline íleo & 56,35 & 60,20 & 62,44 & 57,88 & 44,70 & 48,54 \\
\hline Média \pm DP & \multicolumn{2}{|c|}{$58,27 \pm 9,86^{A d}$} & \multicolumn{2}{|c|}{$60,16 \pm 11,99^{A}$} & \multicolumn{2}{|c|}{$46,64 \pm 6,84^{\mathrm{Ba}}$} \\
\hline
\end{tabular}

${ }^{a b c d}$ Médias seguidas de letras diferentes na mesma coluna diferem entre si pelo teste de Tukey $(P<0,05)$.

${ }^{A B}$ Médias seguidas de letras diferentes na mesma linha diferem entre si pelo teste de Tukey $(P<0,05)$.

${ }^{1}$ Controle - bezerros referentes às vacas do tratamento com vitamina $\mathrm{E} ;{ }^{2} \mathrm{ST}$ - bezerros referentes às vacas do tratamento com rbST (somatotropina bovina recombinante); ${ }^{3} \mathrm{DP}=$ desvio padrão. 
Nos animais abatidos aos sete dias de vida todos os segmentos tiveram seu volume reduzido em comparação aos animais abatidos aos dois dias, com exceção do jejuno médio, o qual se manteve sem alteração e apresentou o maior $V_{v}(P<0,05)$ em relação aos outros segmentos na referida data. Van Ginneken et al. (2002), estudando o desenvolvimento da mucosa intestinal de suínos recém-nascidos e no período pós-desmama, observaram que, independente do estágio de desenvolvimento, o $\mathrm{V} v$ da mucosa foi menor no duodeno em comparação ao jejuno e íleo. Segundo os autores, esta observação sugere que as vilosidades desses segmentos podem ser maiores e mais numerosas, aliado ao fato de possuírem uma parede intestinal mais delgada em relação aos outros segmentos. Resultados semelhantes foram observados no presente estudo, com exceção dos animais abatidos aos dois dias de idade, em que os $\mathrm{V} v$ dos segmentos não diferiram, no entanto, como já mencionado anteriormente, fato que pode estar relacionado com a fase transitória do epitélio.

Houle et al. (1997), trabalhando com suplementação oral de IGF-I (200 $\mu \mathrm{g} / \mathrm{kg}$ de peso vivo, por sete ou 14 dias), não observaram diferenças quanto ao comprimento ou peso do intestino delgado de suínos. No entanto, os autores verificaram um aumento de 40 a 60\% na altura das vilosidades na porção do íleo. Burrin et al. (1996), também trabalhando com suínos consumindo rhIGF-I (3500 $\mu \mathrm{g} / \mathrm{kg}$ de peso vivo, por quatro dias), verificaram aumento significativo da altura das vilosidades do jejuno e íleo. No entanto, nos dois estudos não foram encontradas diferenças quanto a profundidade de cripta e espessura da camada muscular. Já Roffler et al. (2003), suplementado bezerros com hIGF-I em quantidades suprafisiológicas (concentração de IGF-I oito a dez vezes maiores às encontradas no colostro), não observaram diferenças quanto as características histomorfológicas ou taxas de proliferação das células na cripta em relação aos animais controle ingerindo uma fórmula contendo somente traços de fatores não-nutricionais. Burrin et al. (1995) observaram que leitões 
consumindo colostro por 24 horas após o nascimento apresentaram maior taxa de síntese de proteína na porção do jejuno em comparação aos animais consumindo leite.

Já Bühler et al. (1998), fornecendo colostro com concentração média de IGF-I de $321 \mathrm{ng} / \mathrm{mL}$ por três dias em duas refeições diárias, colostro somente na primeira refeição ou sucedâneo por um período de sete dias para bezerros, verificaram que o colostro por um período prolongado aumentou significativamente a área e o tamanho das vilosidades do duodeno, não influenciando os segmentos mais distais do intestino. Resultados semelhantes foram obtidos por Blättler et al. (2001), os quais trabalhando com fornecimento de colostro por sete dias observaram que esses animais apresentaram maior altura de vilosidades somente na porção do duodeno em comparação aos animais controle. Essa informação pode estar relacionada ao fato da porção proximal do intestino receber componentes parcialmente digeridos $\mathrm{e}$ componentes com atividade biológica preservada do quimo. No entanto, os autores também observaram uma redução na proliferação de células epiteliais, sugerindo que o fornecimento de altas concentrações de colostro por um período prolongado pode aumentar a sobrevivência das células epitelias concomitantemente com uma redução da taxa de turnover.

No presente estudo não foi verificado aumento significativo $(P>0,05)$ no $\mathrm{Vv}$ do segmento do duodeno nas diferentes datas de abate, tendo o mesmo apresentado menor $V v$ em relação aos outros segmentos ao nascimento e aos sete dias de idade. 
Assim, sugere-se que, além do IGF-I, outros fatores biologicamente ativos e os nutrientes presentes no colostro podem estar envolvidos nas mudanças relacionadas ao desenvolvimento da mucosa intestinal na primeira semana de vida. Adicionalmente, as diferenças observadas do $\mathrm{V} v$ nas diferentes idades experimentais podem estar relacionadas à transição da primeira geração de células. 


\section{CONCLUSÕES}

\subsection{Conclusões gerais}

As concentrações das proteínas séricas das vacas variaram significativamente em função do período experimental, diferindo na amplitude e refletindo as grandes mudanças que ocorrem no mês final de gestação. 0 tratamento com rbST no período pré-parto resultou em aumentos nas concentrações de IGF-I na circulação materna e no colostro, porém não influenciou as demais secreções lácteas. O fornecimento de colostro de alto valor imunológico nas primeiras horas de vida e em quantidades adequadas, proporcionou aos bezerros na primeira semana de vida concentrações séricas elevadas de IgG e PT. No entanto, os altos níveis de IGF-I observados no colostro não influenciaram os níveis de IGF-I circulantes dos bezerros na primeira semana de vida, bem como o volume parcial da mucosa absortiva do intestino delgado. Possíveis alterações na concentração sérica de IGF-I nesta fase podem estar relacionadas a um conjunto de fatores presentes nas secreções lácteas, como também a produção endógena. Independente da concentração sérica, altas concentrações de IGF-I no colostro podem agir localmente mediando $\mathrm{o}$ desenvolvimento do trato gastrintestinal $\mathrm{e}$ conseqüentemente a habilidade de absorção. O estabelecimento da ação da rbST sobre o sistema imune e possível alteração das secreções lácteas trariam importantes possibilidades de tratamento e manejo. 


\subsection{Conclusões finais}

O comportamento da flutuação de IGF-I e IgG séricos é semelhante no período pré-parto.

O tratamento com rbST no período seco influenciou somente a concentração de IGF-I no colostro.

A concentração de IGF-I no colostro não teve efeito sobre as concentrações séricas nos bezerros até sete dias de vida, bem como sobre o volume parcial da mucosa absortiva do intestino delgado. 


\section{REFERÊNCIAS BIBLIOGRÁFICAS}

ASSOCIATION OF OFFICIAL ANALYTICAL CHEMISTS. Official methods of analysis. 12.ed. Washington, 1975. 1094p.

ATTAIX, D.; MESLIN, J.C. Changes in small intestinal mucosa morphology and cell renewal in suckling, prolonged-suckling, and weaned lambs. American Journal of Physiology, v.261, n.4, p.811-818, Oct. 1991.

BADDELEY, A.; GUNDERSEN, H.J.G.; CRUZ-ORIVE, L.M. Estimation of surface area from vertical sections. Journal of Microscopy, v.42, n.3, p.259-276, June 1986.

BALLARD, F.J.; WALLACE, J.C.; FRANCIS, G.L.; READ, L.C.; TOMAS, F.M. Des(1-3)IGF-I: a truncated form of insulin-like growth factor-I. International Journal of Biochemistry Cell Biology, v.28, n.10, p.1085-1087, Oct. 1996.

BARACAT, R.S.; MACHADO NETO, R.; DANIELE, C.; BESSI, R.; PACKER, I.U. Fornecimento prolongado de colostro e proteção passiva em bezerros recém-nascidos. Pesquisa Agropecuária Brasileira, v.32, n.11, p.215-220, nov. 1997.

BAUMAN, D.E.; PEEL, C.J.; STEINHOUR, W.D.; REYNOLDS, P.J.; TYRRELL, H.F.; BROWN, A.C.G.; HAALAND, G.L. Effect of bovine somatotropin on metabolism of lactating dairy cows: influence on rates of irreversible loss and oxidation of glucose and nonesterified fatty acids. Journal of Nutrition, v.118, n.8, p.1031-1040, Aug. 1988. 
BAUMRUCKER, C.R.; BLUM, J.R. Secretion of insulin-like growth factors in milk and their effect on the neonate. Livestock Production Science, v.35, n.1/2, p.49-72, May 1993.

BAUMRUCKER, C.R.; HADSELL, D.L.; BLUM, J.W. Effects of dietary insulinlike growth factor-I on growth and insulin-like growth factor receptors in neonatal calf intestine. Journal of Animal Science, v.71, n.2, p.428-433, Feb. 1994.

BESSER, T.E.; GAY, C.C. The importance of colostrum to the health of neonatal calf. Veterinary Clinics of North America: Food Animal Practice, v.10, n.1, p.107-115, Mar. 1994.

BESSER, T.E.; GARMEDIA, A.E.; McGUIRE, T.C. Effects of colostral immunoglobulin $G_{1}$ and immunoglobulin $M$ concentrations on immunoglobulin absorption in calves. Journal of Dairy Science, v.68, n.8, p.2033-2037, Aug. 1985.

BESSI, R. Efeito de selênio e vitamina E sobre o desenvolvimento imunológico de bezerros. Piracicaba, 1996. 102p. Dissertação (Mestrado) - Escola Superior de Agricultura "Luiz de Queiroz", Universidade de São Paulo.

BESSI, R.; PAULETTI, P.; d'ARCE, R.D.; MACHADO NETO, R. Absorção de anticorpos do colostro em bezerros. I. Estudo no intestino delgado proximal. Revista Brasileira de Zootecnia. v.31, n.6, p.2314 - 2324, nov. 2002a.

BESSI, R.; PAULETTI, P.; d'ARCE, R.D.; MACHADO NETO, R. Absorção de anticorpos do colostro em bezerros. II. Estudo no intestino delgado distal. Revista Brasileira de Zootecnia. v.31, n.6, p.2325 - 2331, nov. 2002b. 
BLÄTTLER, U.; HAMMON, H.M.; MOREL, C.; PHILIPONA, C.; RAUPRICH, A.; ROMÉ, V.; HUËROU-LURON, I.; GUILLOTEU, P.; BLUM, J.W. Feeding colostrum, its composition and feeding variably modify proliferation and morphology of the intestine and digestive enzyme activities of neonatal calves. Journal of Nutrition, v.131, n.4, p.1256-1263, Apr. 2001.

BLUM, J.W.; HAMMON, H. Colostrum effects on the gastrointestinal tract, and on nutritional, endocrine and metabolic parameters in neonatal calves. Livestock Production Science, v.66, n.2, p.151-159, Oct. 2000.

BRAMBELL, F.W.R. The passive immunity of the young mammal. Biological Reviews, v.33, n.4, p.488-531, Nov. 1958.

BRANDON, M.R.; WATSON, D.L.; LASCELLES, A.K. The mechanism of transfer of immunoglobulins into mammary secretions of cows. Australian Journal of Experimental Biology and Medical Science, v.49, p.613-623, Dec. 1971.

BREIER, B.H.; GLUCKMAN, P.D.; BASS, J.J. Plasma concentrations of insulinlike growth factor-I and insulin in the infant calf: ontogeny and influence of altered nutrition. Journal of Endocrinology, v.119, n.1, p.43-50, Oct. 1988.

BÜHLER, C.; HAMMON, H.; ROSSI, G.L.; BLUM, J.W. Small intestinal morphology in eight-day-old calves fed colostrum for different durations or only milk replacer and treated with long- $R_{3}$-insulin-like growth factor-I and growth hormone. Journal of Animal Science, v.76, n.3, p.758-765, Mar. 1998.

BURRIN, D.G.; FIOROTTO, M.L.; HADSELL, D.L. Transgenic hypersecretion of des(1-3) human insulin-like growth factor I in mouse milk has limited effects on the gastrointestinal tract in suckling pups. Journal of Nutrition, v.129, n.1, p.51-56, Jan. 1999.

BURRIN, D.G.; WESTER, T.J.; DAVIS, T.A.; AMICK, S. Orally administered 
insulin-like growth factor-I increases intestinal mucosal growth in formulafed neonatal pigs. American Journal of Physiology, v.270, n.5, p.10851091, May 1996.

BURRIN, D.G.; DAVIS, T.A.; EBNER, S.; SCHOKNECHT, P.A.; FIOROTTO, M.L.; REEDS, P.J.; McAVOY, S. Nutrient-independent and nutrientdependent factors stimulate protein synthesis in colostrum-fed newborn pigs. Pediatric Research, v.37, n5, p. 593-599, May 1995.

BURTON, J.L.; KENNEDY, B.W.; BURNSIDE, B.N.; WILKE, B.N.; BURTON, J.H. Variation in serum concentrations of immunoglobulins $G, A$ and $M$ in Canadian Holstein-Friesian calves. Journal of Dairy Science, v.72, n.1, p.135-149, Jan. 1989.

BURTON, J.L.; McBRIDE, B.W.; BLOCK, E.; GLIMM, D.R.; KENNELLY, J.J. A review of bovine growth hormone. Canadian Journal of Animal Science, v.74, n.2, p.167-201, June 1994.

BURTON, J.L.; McBRIDE, B.W.; KENNEDY, B.W.; BURTON, J.H.; ELSASSER, T.H.; WOODWARD, B. Serum immunoglobulin profiles of dairy cows chronically treated with recombinant bovine somatotropin. Journal of Dairy Science, v.74, n.5, p.1589-1598, Mar. 1991a.

BURTON, J.L.; McBRIDE, B.W.; KENNEDY, B.W.; BURTON, J.H.; ELSASSER, T.H.; WOODWARD, B. Influence of exogenous bovine somatotropin on the responsiveness of peripheral blood lymphocytes to mitogen. Journal of Dairy Science, v.74, n.3, p.916-928, Mar. 1991b.

BURTON, J.L.; McBRIDE, B.W.; KENNEDY, B.W.; BURTON, J.H.; ELSASSER, T.H.; WOODWARD, B. Contact sensitivity and systemic antibody responses in dairy cows treated with recombinant bovine somatotropin. Journal of Dairy Science, v.75, n.3, p.747-755, Mar. 1992.

BUTLER, A.A.; YAKAR, S.; GEWOLB, I.H.; KARAS, M.; OKUBO, Y.; LeROITH, D. Insulin-like growth factor-I receptor signal transduction: at the interface 
between physiology and cell biology. Comparative Biochemistry and Physiology, v.121, n.1, p.19-26, Sept. 1998.

CAMPBELL, P.G.; BAUMRUCKER, C.R. Insulin-like growth factor-I and its association with biding proteins in bovine milk. Journal of Endocrinology, v.120, n.1, p.21-29, Jan. 1989.

CAMPBELL, P.G.; SKAAR, T.C.; VEGA, J.R.; BAUMRUCKER, C.R. Secretion of insulin-like growth factor-I (IGF-I) and IGF-binding proteins from bovine mammary tissue in vitro. Journal of Endocrinology, v.128, n.2, p.219-228, Feb. 1991.

CLARK, R. The somatogenic hormones and insulin-like growth factor-1: Stimulators of lymphopoiesis and immune function. Endocrine Reviews, v.18, n.2, p.157-179, Apr. 1997.

COHICK, W.S. Role of the insulin-like growth factors and their binding proteins in lactation. Journal of Dairy Science, v.81, n.6, p.1769-1777, June 1998.

COLLET, C.; CANDY, J. How many insulin-like growth factor binding proteins? Molecular and Cellular Endocrinology, v.139, n.1/2, p.1-6, Apr. 1998.

CORDANO, P.; HAMMON, H.M.; MOREL, C.; ZURBRIGGEN, A.; BLUM, J.W. mRNA of insulin-like growth factor (IGF) quantification and presence of IGF binding proteins, and receptors for growth hormone, IGF-I and insulin, determined by reverse transcribe polymerase chain reaction, in the liver of growing and mature cattle. Domestic Animal Endocrinology, v.19, n.3, p.191-208, Oct. 2000. 
COVERLEY, J.A.; BAXTER, R.C. Phosphorylation of insulin-like growth factor binding proteins. Molecular and Cellular Endocrinology, v.128, n.1/2, p.1-5, Apr. 1997.

CZECH, M.P. Signal transmission by the insulin-like growth factors. Cell, v.59, n.2, p.235-238, Oct. 1989.

DANIELE, C.; MACHADO NETO, R.; BARACAT, R.S.; BESSI, R.; PACKER, I.U. Efeito de diferentes manejos no fornecimento prolongado de colostro sobre o comportamento imunológico e desempenho de bezerros leiteiros recém-nascidos. Revista da Sociedade Brasileira de Zootecnia, v.23, n.2, p.211-222, mar./abr. 1994.

DePALO, E.F.; BASSANELLO, M.; LANCERIN, F.; SPINELLA, P.; GATTI, R.; d'AMICO, D.; CILLO, U. GH/IGF system, cirrhosis and liver transplantation. Clinica Chimica Acta, v.310, n.1, p.31-37, Aug. 2001.

DIXON, F.J.; WEIGLE, W.O.; VAZQUEZ, J.J. Metabolism and mammary secretion of serum proteins in the cow. Laboratory Investigation, v.10, n.2, p.216-236, 1961.

DONOVAN, S.M.; CHAO, J.C.J.; ZIJLSTRA, R.T.; ODLE, J. Orally administered iodinated recombinant human insulin-like growth factor-I (125-rhIGF-I) is poorly absorbed by the newborn piglet. Journal of Pediatric Gastroenterology and Nutrition, v.24, n.2, p.174-182, Feb. 1997.

DONOVAN, S.M.; HINTZ, R.L.; WILSON, D.M.; ROSENFELD, R.G. Insulin-like growth factors I and II and their binding proteins in rat milk. Pediatric Research, v.29, n.1, p.50-55, Jan. 1991. 
DONOVAN, S.M.; McNEIL, L.K.; JIMÉNEZ-FLORES, R.; ODLE, J. Insulin-like growth factors and insulin-like growth factor binding proteins in porcine serum and milk throughout lactation. Pediatric Research, v.36, n.2, p.159168, Aug. 1994.

EGLI, C.P.; BLUM, J.W. Clinical, haematological, metabolic and endocrine traits during the first three months of life of suckling Simmentaler calves held in a cow-calf operation. Journal of Veterinary Medical Association, v.45, n.2, p.99-118, Mar. 1998.

FELLAH, A.M.; PHILIPPS, A.F.; GILLESPIE, T.J.; GALO, J.R.; DVORAK, B. Degradation of insulin-like growth factros in small intestine of suckling rats. Regulatory Peptides, v.98, n.1/2, p.19-25, Apr. 2001.

FERRY, R.J.; LIU, B.R.; COHEN, P. New roles for IGF binding proteins. Endocrinologist, v.9, n.6, p.438-450, Nov./Dec. 1999.

FLEENOR, W.A.; STOTT, G.H. Hydrometer test for estimation of immunoglobulin concentration in bovine colostrum. Journal of Dairy Science, v.63, n.6, p.973-977, June 1980.

FOLEY, J.A.; OTTERBY, D.E. Availability, storage, treatment composition and feeding value of surplus colostrum: a review. Journal of Dairy Science, v.61, n.8, p.1033-1060, Aug. 1978.

FRANCIS, G.L.; UPTON, F.M.; BALLARD, F.J.; McNEIL, K.A.; WALLACE, J.C. Insulin-like grotwh factors 1 and 2 in bovine colostrum. Sequences and biological activities compared of a potent truncated form. Biochemistry Journal, v.251, n.1, p.95-103, Apr. 1998.

GALLO, G.F.; BLOCK, E. Effects of recombinant bovine somatotropin on nutritional status of dairy cows and of their calves. Journal of Dairy Science, v.73, n.11, p.3266-3275, Nov. 1990.

GAY,C.C. Colostrum research says... fed 4 quarts for healthier calves. Hoard's 
Dairyman, v.139, n.6, p.256, 1994.

GLIMM, D.R.; BARACOS, V.E.; KENNELLY, J.J. Effect of bovine somatrotopin on the distribution of immunoreactive insulin-like growth factor-I in lactating mammary tissue. Journal of Dairy Science, v.71, n.11, p.2923-2935, Nov. 1988.

GROSVENOR, C.E.; PICCIANO, M.F.; BAUMRUCKER, C.R. Hormones and growth factors in milk. Endocrine Reviews, v.14, n.6, p.710-728, Nov. 1993.

GULAY, M.S.; HAYEN, M.J.; BACHMAN, K.C.; BELLOSO, T.; LIBONI, M.; HEAD, H.H. Milk production and feed intake of Holstein cows given short (30-d) or normal (60-d) dry periods. Journal of Dairy Science, v.86, n.6, p.2030-2038, June 2003.

HADSELL, D.L.; BAUMRUCKER, C.R.; KENSINGER, R.S. Effects of elevated blood insulin-like growth factor-I (IGF-I) concentration upon IGF-I in bovine mammary secretions during the colostrum phase. Journal of Endocrinology, v.137, n.2, p.223-230, May 1993.

HADSELL; D.L.; CAMPBELL, P.G.; BAUMRUCKER, C.R. Characterization of the change in type I and II insulin-like growth factor receptors of bovine mammary tissue during the pre and postpartum periods. Endocrinology, v.126, n.1, p. 637-643, Jan. 1990.

HAMMON, H.; BLUM, J.W. The somatotropic axis in neonatal calves can be modulated by nutrition, growth hormone, and long-R3-IGF-I. American Journal of Phisiology, v.273, n.1, p.E130-E138, July 1997. 
HAMMON, H.M.; ZANKER, I.A.; BLUM, J.W. Delayed colostrum feeding affects IGF-I and insulin plasma concentrations in neonatal calves. Journal of Dairy Science, v.83, n.1, p.85-92, Jan. 2000.

HAMMON, H.M.; SCHIESSLER, G.; NUSSBAUM, A.; BLUM, J.W. Feed intake patterns, growth performance, and metabolic and endocrine traits in calves fed unlimited amounts of colostrum and milk by automate, starting in the neonatal period. Journal of Dairy Science, v.85, n.12, p.3352-3362, Dec. 2002.

HARDON, U.; HAMMON, H.; BRUCKMAIER, R.M.; BLUM, J.W. Delaying colostrum intake by one day has important effects on metabolic traits and on gastrointestinal and metabolic hormones in neonatal calves. Journal of Nutrition, v.127, n.10, p.2011-2023, Oct. 1997.

HARRELL, R.J.; THOMAS, M.J.; BOYD, R.D.; CZERWINSKI, S.M.; STEELE, N.C.; BAUMAN, D.E. Ontogenic maturation of the somatotropin/insulin-like growth factor axis. Journal of Animal Science, v.77, n.11, p.2934-2941, Nov. 1999.

HOSSNER, K.L.; McCUSKER, R.H.; DODSON, M.V. Insulin-like growth factors and their binding proteins in domestic animals. Animal Science, v.64, n.1, p.1-15, Feb. 1997.

HOULE, V.M.; SCHROEDER, E.A.; ODLE, J.; DONOVAN, S.M. Small intestinal disaccharidase activity and ileal villus height are increased in piglets consuming formula containing recombinat human insulin-like growth factor-I. Pediatric Research, v.42, n.1, p.78-86, July 1997.

HUSBAND, A.J.; BRANDON, M.R.; LASCELLES, A.K. Absorption and endogenous production of immunoglobulins in calves. Australian Journal of Experimental Biology and Medical Science, v.50, n.4, p.491-498, Sept. 1972.

JAMES, R.E.; POLAN, C.E., McGILLIARD, M.L. Distribution uptake of $\gamma$ - 
globulin in small intestine of neonatal calves. Journal of Dairy Science, v.62, n.9, p.1415-1419, Sept. 1979.

JEFFCOTT, L.B. Passive immunity and its transfer with special reference to the horse. Biological Reviews, v.47, n.4, p.439-464, Nov. 1972.

JOCHIMS, K.; KAUP, F.-J.; DORMMER, W. An immunoelectron microscopic investigation of colostral IgG absorption across the intestine of newborn calves. Research in Veterinary Science, v.57, n.1, p.75-80, July 1994.

JONES, J.I.; CLEMMONS, D.R. Insulin-like growth factors and their binding proteins: biological actions. Endocrinology Reviews, v.16, n.1, p.3-34, Feb. 1995.

KEARL, L.C. Nutrient requirements of ruminants in developing countries. Logan: Utah State University, 1982. 381p.

KELLEY, K.M.; YOUGMAN, O.H.; GARGOSKY, S.E.; GUCEV, Z.; MATSUMOTO, T.; VIVIAN, H.W.A.; LILLY, N.G.; SIMPSON, D.M.; ROSENFELD, R.G. Insulin-like growth factor-binding proteins (IGFBPs) and their regulatory dynamics. International Journal of Biochemistry Cell Biology, v.28, n.6, p.619-637, June 1996.

KERR, D.E.; LAARVELD, B.; FEHR, M.I.; MANNS, J.G. Profiles of serum IGF-I concentrations in calves from birth to eighteen months of age and in cows throughout the lactation cycle. Canadian Journal of Animal Science, v.71, n.3, p.695-705, Sept. 1991.

KIESS, W.; YANG, Y.; KESSLER, U.; HOEFLICH, A. Insulin-like growth factorII (IGF-II) and IGF-II/Manose-6-phosphate receptor: the myth continues. Hormone Research, v.41, suppl.2., p.66-73, May 1994. 
KRUSE, P. E. Absorption of immunoglobulin from colostrum in newborn calves. Animal Production, v.12, n.4, p.627-638, Nov. 1970.

KRUSE, P.E. The importance of colostral immunoglobulin and their absorption from the intestine of the newborn animals. Annales de Recherches Veterinaires, v.14, n.4, p.349-353, 1983.

KÜHNE, S.; HAMMON, H.M.; BRUCKMAIER, R.M.; MOREL, C.; ZBINDEN, Y.; BLUM, J.W. Growth performance, metabolic and endocrine traits, and absorptive capacity in neonatal calves fed either colostrum or milk replacer at two levels. Journal of Animal Science, v.78, n.3, p.609-620, Mar. 2000.

LANNA, D.P.D.; HOUSEKNECHT, K.L.; HARRIS, D.M.; BAUMAN, D.E. Effects of somatotropin treatment on lipogenesis, lipolysis and related cellular mechanisms in adipose tissue of lactating cows. Journal of Dairy Science, v.78, n.8, p.1703-1712, Aug. 1995.

LARSON, B.L.; KENDALL, K.A. Changes in specific blood serum protein levels associated with parturition in the bovine. Journal of Dairy Science, v.40, n.6, p.659-666, 1957.

LECCE, J.D.; MORGAN, D.O. Effect of dietary regime on cessation of intestinal absorption of large molecules (closure) in the neonatal pig and lamb. Journal of Nutrition, v.78, n.3, p.263-268, Nov. 1962.

LEE, P.D.K.; CONOVER, C.A.; POWELL, D.R. Regulation and function of insulin-like growth factor-binding protein-1. Proceedings of the Society for Experimental Biology and Medicine, v.204, n.1, p.4-29, Oct. 1993.

LeROITH, D.L. Insulin-like growth factor. Hormone and Metabolic Research, v.31, n.2/3, p.41-42, Feb./Mar. 1999. 
LeROITH, D.; SAMPSON, P.C.; ROBERTS, C.T. How does the mitogenic insulin-like growth factor I receptor differ from the metabolic insulin receptor? Hormone Research, v.41, n.2, p.74-79, May 1994.

MA, L.; XU, R.J. Oral insulin-like growth factor-I stimulates intestinal enzyme maturation in newborn rats. Life Sciences, v.61, n.1, p.51-58, May 1997.

MAcDONALD, R.S. The role of insulin-like growth factors in small intestinal cell growth and development. Hormone and Metabolic Research, v.31, n.2/3, p.103-113, Feb./Mar. 1999.

MACEWKO, N.; ANGLISS, G.A.; JONES, E.F.; GOVONI, K.E.; LOUGHLIN, M.F.; CISSEL, D.; ZINN, S.A.; SCHREIBER, D.; HOAGLAND, T.A. The influence of pre-calving somatotropin on the quantity and quality of colostrum in beef cattle. Journal of Dairy Science, v.85, n.1, p.353, Jan. 2002

MACHADO NETO, R.; PACKER, I.U. Flutuação de imunoglobulina sérica em bezerros da raça Holandesa submetidos a diferentes regimes de aleitamento. Revista da Sociedade Brasileira de Zootecnia, v.15, n.5, p.439-447, set./out. 1986.

MACHADO NETO, R.; PACKER, I.U.; BONILHA, L.M.; FIGUEIREDO, L.A.; RAZZOK, A.G.; CÂNDIDO, J.G. Concentração de IgG sérica em bezerros das raças Nelore, Guzerá, Gir e Caracu. 2. Efeitos sobre crescimento e mortalidade até a desmama. Revista Brasileira de Zootecnia, v.26, n.5, p.920-923, set./out. 1997.

MALVEN, P.V.; HEAD, H.H.; COLLIER, R.J.; BUONOMO, F.C. Periparturient changes in secretion and mammary uptake of insulin and in concentrations of insulin and insulin-like growth factors in milk of dairy cows. Journal of Dairy Science, v.70, n.11, p.2254-2265, Nov. 1987. 
MANCINI, G.; CARBONARA, A.O.; HERMANS, J.F. immunochemical quantitation of antigens by single radial immunodiffusion. Immunochemistry, v.2, n.3, p.253-254, Sept. 1965.

McCUSKER, R.H. Controlling insulin-like growth factor activity and the modulation of insulin-like growth factor binding protein and receptor binding. Journal of Dairy Science, v.81, n.6, p.1790-1800, June 1998.

McGUIRE, M.A.; BAUMAN, D.E.; DWYER, D.A.; COHICK, W.S. Nutritional modulation of the somatotropin/insulin-like growth factors system: Response to feed deprivation in lactating cows. Journal of Nutrition, v.125, n.3, p.493-502, Mar. 1995.

MORGAN, C.J.; COUTTS, A.G.P.; McFADYEN, M.C.; KING, T.P.; KELLY, D. Characterization of IGF-I receptors in the porcine small intestine during postnatal development. Nutritional Biochemistry, v.7, n.6, p.339-347, June 1996.

MORIN, D.E.; McCOY, G.C.; HURLEY, W.L. Effects of quality, quantity, and timing of colostrum feeding and addition of a dried colostrum supplement on immunogloblin $G_{1}$ absorption in Holstein bull calves. Journal of Dairy Science, v.80, n.4, p.747-753, Apr. 1997.

MORIN, D.E.; CONSTABLE, P.D.; MAUNSELL, F.P.; McCOY, G.C. Factors associated with colostral specific gravity in dairy cows. Journal of Dairy Science, v.84, n.4, p-937-943, Apr. 2001.

NOCEK, J.E.; BRAUND, D.G.; WARNER, R.G. Influence of neonatal colostrum administration, immunoglobulin, and continued feeding colostrum on calf gain, health and serum protein. Journal of Dairy Science, v.67, n.2, p.319333, Feb. 1984. 
NUSSBAUM, A.; SCHIESSLER, G.; HAMMON, H.M.; BLUM, J.W. Growth performance and metabolic and endocrine traits in calves pair-fed by bucket or by automate starting in the neonatal period. Journal of Animal Science, v.80, n.6, p.1545-1555, June 2002.

ODLE, J.; ZIJLSTRA, R.T.; DONOVAN, S.M. Intestinal effects of milk borne growth factors in neonates of agricultural importance. Journal of Animal Science, v.74, n.10, p.2509-2522, Oct. 1996.

OLANREWAJU, H.A.; SANZENBACHER, E.D.; SEIDEL, E.R. Insulin-like growth factor I in suckling rat gastric contents. Digestive Diseases and Sciences, v.41, n.7, p.1392-1397, July 1996.

PAULETTI, P., MACHADO NETO, R., PACKER, I.U., BESSI, R. Avaliação de níveis séricos de imunoglobulina, proteína e o desempenho de bezerras da raça Holandesa. Pesquisa Agropecuária Brasileira, v.37, n.1, p.89-94, jan. 2002.

PHILIPPS, A.F.; RAO, R.K.; ANDERSON, G.G.; McCRACKEN, D.M.; LAKE, M.; KOLDOVSKY, O. Fate of insulin-like growth-factors-I and growth-factors-II administered orogastrically to suckling rats. Pediatric Research, v.37, n.5, p.586-592, May 1995.

PRITCHETT, L.C.; GAY, C.C.; BESSER, T.E.; HANCOCK, D. Management and production factors influencing immunoglobulin $G_{1}$ concentration in colostrum from Holstein cows. Journal of Dairy Science, v.74, n.7, p.2336-2341, July 1991.

PROSSER, C.G.; FLEET, I.R.; CORPS, A.N. Increased secretion of insulin-like growth factor-I into milk of cows treated with recombinantly derived growth hormone. Journal of Dairy Research, v.56, n.1, p.17-26, Feb. 1989. 
PUTNAM, D.E.; VARGA, G.A.; DANN, H.M. Metabolic and production responses to dietary protein and exogenous somatotropin in late gestation dairy cows. Journal of Dairy Science, v.82, n.5, p.982-995, May 1999.

QUIGLEY, J.D.; DREWRY, J.J. Nutrient and immunity transfer from cow to calf pre- and postcalving. Journal of Dairy Sicence, v.81, n.10, p.2779-2790, Oct. 1998.

QUIGLEY, J.D.; KOST, C.J.; WOLFE, T.M. Absorption of protein and IgG in calves fed a colostrum supplement or replacer. Journal of Dairy Science, v.85, n.5, p.1243-1248, May 2002.

RAUPRICH, A.B.E.; HAMMON, H.M.; BLUM, J.W. Influence of feeding different amounts of first colostrum on metabolic, endocrine, and health status, and growth performance in neonatal calves. Journal of Animal Science, v.78, n.4, p.896-908, Apr. 2000.

RECHLER, M.M.; CLEMMONS, D.R. Regulatory actions of insulin-like growth factor-binding proteins. Trends in Endocrinology and Metabolism, v.9, n.5, p.176-183, July 1998.

REINHOLD, J.G. Total protein, albumin and globulin. In: REINER, M. Standard methods of clinical chemistry. New York: Academic Press, 1953. p.88.

RHOADS, R.P.; GREENWOOD, P.L.; BELL, A.W.; BOISCLAIR, Y.R. Nutritional regulation of the genes encoding the acid-labile subunit and other components of the circulating insulin-like growth factor system in the sheep. Journal of Animal Science, v.78, n.10, p.2681-2689, Oct. 2000.

RIBEIRO, M.F.B.; BELEM, P.A.D.; PATARROYO, J.H.S.; FARIA, J.E. de. Hipogamaglobulinemia em bezerros. Arquivo Brasileiro de Medicina Veterinária e Zootecnia, v.35, n.4, p.537-546, ago. 1983.

ROFFLER, B.; FAH, A.; SAUTER, S.N.; HAMMON, H.M.; GALLMANN, P.; 
BREM, G.; BLUM, J.W. Intestinal morphology, epithelial cell proliferation, and absorptive capacity in neonatal calves fed milk-born insulin-like growth factor-I or a colostrum extract. Journal of Dairy Science, v.86, n.5, p.17971806, May 2003.

RONGE, H.; BLUM, J.W. Somatomedin C and other hormones in dairy cows around parturition, in newborn calves and in milk. Journal of Animal Phisiology and Animal Nutrition, v.60, n.3, p.168-176, Sept. 1988.

ROSI, F.; PINOTTI, L. Slow-release somatotropin reduces plasma leptin in lactating dairy cows. Journal of Dairy Science, v.85, n.1, p.353, Jan. 2002.

SALMON, $\mathrm{H}$. The mammary gland and neonate mucosal immunity. Veterinary Immunology and Immunopathology, v.72, n.1/2, p.143-155, Dec. 1999.

SAS INSTITUTE. SASISTAT: user's guide; release 6.08 ed. Cary, 1991. 1028p.

SASAKI, M.; DAVIS, C.L.; LARSON, B.L. Production and turnover of $\operatorname{lgG}_{1}$ and $\mathrm{IgG}_{2}$ immunoglobulins in the bovine around parturation. Journal of Dairy Science, v.59, n.12, p. 2046-2055, Dec. 1976.

SCHMIDT, G.H. Biology of lactation. San Francisco: W. H. Freeman, 1971. $317 p$.

SCHOBER, D.A.; SIMMEN, F.A.; HADSELL, D.L.; BAUMRUCKER, C.R. Perinatal expression of type I IGF receptors in porcine small intestine. Endocrinology, v.126, n.2, p.1125-1132, Feb. 1991

SEJRSEN, K.; PEDERSEN, L.O.; VESTERGAARD, M.; PURUP, S. Biological activity of bovine milk. Contribution of IGF-I and IGF binding proteins. Livestock Production Science, v.70, n.1/2, p.79-85, July 2001. 
SHARMA, B.K.; VANDEHAAR, M.J.; AMES, N.K. Expression of insulin-like growth factor-I in cows at different stages of lactation and in late lactation cows treated with somatotropin. Journal of Dairy Science, v.77, n.8, p.2232-2241, Aug. 1994.

SIMMEN, F.A.; SIMMEN, R.C.M.; REINHART, G. Maternal and neonatal somatomedin C/insulin-like growth factor-I (IGF-I) and IGF biding proteins during early lactation in the pig. Developmental Biology, v.130, n.1, p.1627, Nov. 1988.

SIMMONS, C.R.; BERGEN, W.G.; VANDEHAAR, M.J.; SPRECHER, D.J.; SNIFFEN, C.J.; STANISIEWSKI, E.P.; TUCKER, H.A. Protein and fat metabolism in cows given somavubove before parturition. Journal of Dairy Science, v.77, n.7, p.1835-1847, July 1994.

SMITH, R.D.; SNIFFEN, C.J.; PERKINS, B.L. Body condition scoring: a tool to use in herd analysis and management. Ithaca: Cornell University, Department of Animal Science, 1982. 8p.

SMITH, V.R.; ERWIN, E.S. Absorption of colostrum globulins introduced directly into the duodenum. Journal of Dairy Science, v.42, n.2, p.364-365, 1959.

SPARKS, A.L.; KIRKPATRICK, J.G.; CHAMBERLAIN, C.S.; WALDNER, D.; SPICER, L.J. Insulin-like growth factor-I and its binding proteins in colostrum compared to mesuares in serum of Holstein neonates. Journal of Dairy Science, v.86, n.6, p.2022-2029, June 2003.

STALEY, T.E.; BUSH, L.J. Receptor mechanisms of the neonatal intestine and their relationship to immunoglobulin absorption and disease. Journal of Dairy Science, v.68, n.1, p.184-205, Jan. 1985. 
STELWAGEN, K.; GRIEVE, D.G.; McBRIDE, B.W.; REHMAN, J.D. Growth and subsequent lactation in primigravid Holstein heifers after prepartum bovine somatotropin treatment. Journal of Dairy Science, v.75, n.2, p.463-471, Feb. 1992.

STELWAGEN, K.; GRIEVE, D.G.; WALTON, J.S., BALL, J.L.; McBRIDE, B.W. Effect of prepartum bovine somatotropin in primigravid ewes on mammogenesis, milk production, and hormone concentrations. Journal of Dairy Science, v.76, n.4, p.992-1001, Apr. 1993.

TYLER, J.W.; STEEVENS, B.J.; HOSTELER, D.E.; HOLLE, J.M.; DENBIGH, J.L. Colostral immunoglobulin concentrations in Holstein and Guernsey cows. American Journal of Veterinary Research, v.60, n.9, p.1136-1139, Sept. 1999.

VACHER, P.Y.; BLUM, J.W. Age dependency of insulin-like growth factor-I, insulin, protein and immunoglobulin concentration and $\gamma$-glutamyltransferase activity in first colostrum of dairy cows. Milk Science International, v.48, n.8, p.423-426, 1993.

VACHER, P.Y.; BESTETTI, G.; BLUM, J.W. Insulin-like growth factor I absorption in the jejunum of neonatal calves. Biology of the Neonate, v.68, n.5, p.354-367, Nov. 1995.

VALLIMONT, J.E.; VARGA, G.A.; ARIELI, A.; CASSIDY, T.W.; CUMMINS, K.A. Effects of prepartum somatotropin and monensin on metabolism and production of periparturient Holstein dairy cows. Journal of Dairy Science, v.84, n.12, p.2607-2621, Dec. 2001.

VAN GINNEKEN, C.; VAN MEIR, F.; SYS, S.; WEYNS, A. Stereologic characteristics of pig small intestine during normal development. Digestive Diseases and Sciences, v.47, n.4, p.868-878, Apr. 2002. 
VAN SOEST, P.J.; ROBERTSON, P.J.; LEWIS, B.A. Methods for dietary fiber, neutral detergent fiber, and non-starch polysaccharides in relation to animal nutrition. Journal of Dairy Science, v.74, n.10, p.3583-3596, Oct. 1991.

VEGA, J.R.; GIBSON, C.A.; SKAAR, T.C.; HADSELL, D.L.; BAUMRUCKER, C.R. Insulin-like growth factor (IGF)-I and IGF binding proteins in serum and mammary secretions during the dry period and early lactation in dairy cows. Journal of Animal Science, v.69, n.6, p.2538-2547, June 1991.

WATSON, D.L. Immunological functions of the mammary gland and its secretion - comparative review. Australian Journal of Biological Science, v.33, n.4, p.403-422, Aug. 1980.

WEBER, M.S.; PURUP, S.; VESTERGAARD, M.; AKERS, R.M.; SEJRSEN, K. Regulation of local synthesis of insulin-like growth factor-I and binding proteins in mammary tissue. Journal of Dairy Science, v.83, n.1, p.30-37, Jan. 2000.

WILLIAMS, M.R.; MILLAR, P. Changes inserum immunoglobulin levels in Jerseys and Friesians near calving. Research in Veterinary Science, v.26, n.1, p.81-84, 1979.

XU, R.J.; MELLOR, D.J.; BIRTTLES, M.J.; BREIER, B.H.; GLUCKMAN, P.D. Effects of oral IGF-I or IGF-II on digestive organ growth in newborn piglets. Biology of Neonate, v. 66, n.5, p.280-287, Nov. 1994.

ZANKER, I.A.; HAMMON, H.M.; BLUM, J.W. Delayed feeding of first colostrum: are there prolonged effects on hematological, metabolic and endocrine parameters and on growth performance in calves? Journal of Animal Physiology and Animal Nutrition, v.85, n.3/4, p.53-66, Apr. 2001. 
ZAPF, J. Physiological role of the insulin-like growth factor binding proteins. European Journal of Endocrinology, v.132, n.6, p.645-654, June 1995.

ZHAO, X.; GROENWEGEN, P.P.; McBRIDE, B.W.; BURTON, J.H.; ELSASSER, T.H. Radioimmunoassay for insuilin-like growth factor-I in bovine milk. Canadian Journal of Animal Science, v.71, n.3, p.669-674, Sept. 1991.

ZINN, S.A. Bioactive components in milk: introduction. Livestock Production Science, v.50, n.1/2, p.101-103, Oct. 1997.

ZUMKELLER, W. Relantioship between insulin-like growth factor-I and -II and IGF-binding proteins in milk and the gastrointestinal tract: growth and development of the gut. Journal of Pediatric Gastroenterology and Nutrition, v.15, n.4, p.357-369, Nov. 1992. 
APÊNDICE 
Apêndice 1. Médias originais (média \pm desvio padrão) das concentrações séricas de IGF-I, IgG e PT das vacas durante o período de tratamento e na data de parição

\begin{tabular}{|c|c|c|c|c|c|c|}
\hline \multirow[b]{2}{*}{ Trat $^{1}$} & \multicolumn{6}{|c|}{ Semanas de Tratamento } \\
\hline & $1^{\underline{a}}$ & $2^{a}$ & $3^{a}$ & $4^{\mathrm{a}}$ & $5^{\underline{a}}$ & Parto \\
\hline & \multicolumn{6}{|c|}{ IGF-I ng/mL } \\
\hline Controle & $94,96 \pm 42,29$ & $93,40 \pm 39,19$ & $79,88 \pm 42,38$ & $46,45 \pm 29,24$ & $53,50 \pm 29,51$ & $17,89 \pm 11,53$ \\
\hline \multirow[t]{3}{*}{ ST } & $89,56 \pm 44,86$ & $295,17 \pm$ & $101,05 \pm 48,80$ & $201,39 \pm$ & $46,14 \pm 31,63$ & $23,29 \pm 18,59$ \\
\hline & & 150,42 & & 142,96 & & \\
\hline & \multicolumn{6}{|c|}{ IgG mg/mL } \\
\hline Controle & $36,14 \pm 6,62$ & $36,67 \pm 8,65$ & $36,02 \pm 9,02$ & $32,81 \pm 9,19$ & $32,13 \pm 4,03$ & $29,10 \pm 7,19$ \\
\hline \multirow[t]{2}{*}{ ST } & $39,48 \pm 8,55$ & $38,78 \pm 7,70$ & $36,75 \pm 6,57$ & $34,80 \pm 5,60$ & $36,02 \pm 12,37$ & $30,99 \pm 6,12$ \\
\hline & \multicolumn{6}{|c|}{ PT $g / 100 \mathrm{~mL}$} \\
\hline Controle & $9,40 \pm 0,79$ & $9,33 \pm 0,91$ & $8,84 \pm 0,96$ & $8,37 \pm 0,93$ & $8,09 \pm 0,59$ & $7,74 \pm 0,89$ \\
\hline ST & $9,05 \pm 1,06$ & $8,80 \pm 1,26$ & $8,64 \pm 1,26$ & $8,35 \pm 0,97$ & $8,54 \pm 0,55$ & $8,21 \pm 0,91$ \\
\hline
\end{tabular}

${ }^{1}$ Trat: Controle - tratamento com vitamina E, ST - tratamento com rbST (somatotropina bovina recombinante). 
Apêndice 2. Médias originais (média \pm desvio padrão) das concentrações séricas de IGF-I, IgG e PT dos bezerros do nascimento até sete dias de idade

\begin{tabular}{|c|c|c|c|c|c|c|c|c|c|}
\hline \multirow[b]{2}{*}{ Trat $^{1}$} & \multicolumn{9}{|c|}{ Idade } \\
\hline & Oh & $12 \mathrm{~h}$ & 1 dia & 2 dias & 3 dias & 4 dias & 5 dias & 6 dias & 7 dias \\
\hline & \multicolumn{9}{|c|}{ IGF-I ng/mL } \\
\hline Controle & $\begin{array}{c}23,18 \pm \\
22,10\end{array}$ & $\begin{array}{c}43,78 \pm \\
34,42\end{array}$ & $\begin{array}{c}37,72 \pm \\
25,20\end{array}$ & $\begin{array}{c}17,18 \pm \\
14,28\end{array}$ & $\begin{array}{c}29,63 \pm \\
16,43\end{array}$ & $\begin{array}{c}17,40 \pm \\
11,37\end{array}$ & $\begin{array}{c}23,87 \pm \\
12,40\end{array}$ & $\begin{array}{c}37,64 \pm \\
25,47\end{array}$ & $\begin{array}{c}43,92 \pm \\
21,38\end{array}$ \\
\hline \multirow[t]{2}{*}{ ST } & $\begin{array}{c}40,55 \pm \\
31,19\end{array}$ & $\begin{array}{c}54,38 \pm \\
35,40\end{array}$ & $\begin{array}{c}28,82 \pm \\
17,55\end{array}$ & $\begin{array}{c}21,21 \pm \\
19,61\end{array}$ & $\begin{array}{c}27,80 \pm \\
16,44\end{array}$ & $\begin{array}{c}24,58 \pm \\
17,19\end{array}$ & $\begin{array}{c}27,13 \pm \\
19,65\end{array}$ & $\begin{array}{c}31,50 \pm \\
28,00\end{array}$ & $\begin{array}{c}19,56 \pm \\
11,09\end{array}$ \\
\hline & \multicolumn{9}{|c|}{ IgG mg/mL } \\
\hline Controle & $1,16 \pm 1,45$ & $\begin{array}{c}29,11 \pm \\
10,70\end{array}$ & $\begin{array}{c}38,47 \pm \\
10,96\end{array}$ & $38,32 \pm 7,27$ & $\begin{array}{c}35,19 \pm \\
11,76\end{array}$ & $\begin{array}{c}37,41 \pm \\
13,47\end{array}$ & $\begin{array}{c}35,10 \pm \\
12,16\end{array}$ & $\begin{array}{c}35,49 \pm \\
14,41\end{array}$ & $\begin{array}{c}35,13 \pm \\
11,97\end{array}$ \\
\hline \multirow[t]{2}{*}{ ST } & $0,06 \pm 0,02$ & $23,57 \pm 9,42$ & $33,45 \pm 6,60$ & $35,26 \pm 5,56$ & $34,97 \pm 9,64$ & $32,93 \pm 8,10$ & $32,01 \pm 9,67$ & $\begin{array}{c}29,03 \pm \\
11,98\end{array}$ & $\begin{array}{c}29,77 \pm \\
12,77\end{array}$ \\
\hline & \multicolumn{9}{|c|}{ PT g/100mL } \\
\hline Controle & $4,92 \pm 0,45$ & $6,62 \pm 1,03$ & $8,04 \pm 1,25$ & $8,13 \pm 1,29$ & $7,91 \pm 1,31$ & $7,88 \pm 1,50$ & $7,68 \pm 1,29$ & $7,86 \pm 1,17$ & $7,82 \pm 1,11$ \\
\hline ST & $5,11 \pm 0,69$ & $6,79 \pm 1,20$ & $7,95 \pm 1,18$ & $7,80 \pm 1,24$ & $8,21 \pm 0,81$ & $7,60 \pm 0,68$ & $7,60 \pm 0,80$ & $7,68 \pm 0,57$ & $7,64 \pm 0,50$ \\
\hline
\end{tabular}

${ }^{1}$ Trat: Controle - bezerros referentes às vacas do tratamento com vitamina E, ST - bezerros referentes às vacas do tratamento com rbST (somatotropina recombinante bovina. 
Apêndice 3. Médias originais (média \pm desvio padrão) das concentrações séricas de IGF-I (ng/mL) dos bezerros do nascimento até sete dias de idade redistribuídos em dois grupos em função da massa de IGF-I $(\mu \mathrm{g})$ ingerida do colostro

\begin{tabular}{|c|c|c|c|c|c|c|c|c|c|}
\hline \multirow[b]{2}{*}{ Grupo $^{1}$} & \multicolumn{9}{|c|}{ Idade } \\
\hline & Oh & $12 \mathrm{~h}$ & $1 \mathrm{dia}$ & 2 dias & 3 dias & 4 dias & 5 dias & 6 dias & 7 dias \\
\hline 1 & $\begin{array}{c}47,79 \pm \\
35,38\end{array}$ & $\begin{array}{c}39,03 \pm \\
25,63\end{array}$ & $\begin{array}{c}31,83 \pm \\
21,21\end{array}$ & $\begin{array}{c}21,06 \pm \\
17,17\end{array}$ & $\begin{array}{c}26,69 \pm \\
18,88\end{array}$ & $\begin{array}{c}16,49 \pm \\
10,43\end{array}$ & $\begin{array}{c}23,96 \pm \\
18,41\end{array}$ & $\begin{array}{c}31,76 \pm \\
24,50\end{array}$ & $\begin{array}{c}36,11 \pm \\
20,81\end{array}$ \\
\hline 2 & $\begin{array}{c}31,57 \pm \\
24,04\end{array}$ & $\begin{array}{c}62,95 \pm \\
43,89\end{array}$ & $\begin{array}{c}35,50 \pm \\
22,35\end{array}$ & $\begin{array}{c}16,31 \pm \\
10,50\end{array}$ & $\begin{array}{c}32,38 \pm \\
17,02\end{array}$ & $\begin{array}{c}29,11 \pm \\
18,37\end{array}$ & $\begin{array}{c}28,29 \pm \\
11,00\end{array}$ & $\begin{array}{c}39,66 \pm \\
20,54\end{array}$ & $\begin{array}{c}23,89 \pm \\
12,78\end{array}$ \\
\hline
\end{tabular}

${ }^{1}$ Grupo 1: ingestão de 500 a $3000 \mu$ g de IGF-I, Grupo 2: ingestão de 3000 a 6000 gg de IGF-I. 